2
4
4
0

Structural Geology of

the Sun River Canyon

and Adjacent Areas,

Northwestern Montana

GEOLOGICAL SURVEY PROFESIONAL PAPER 663-B
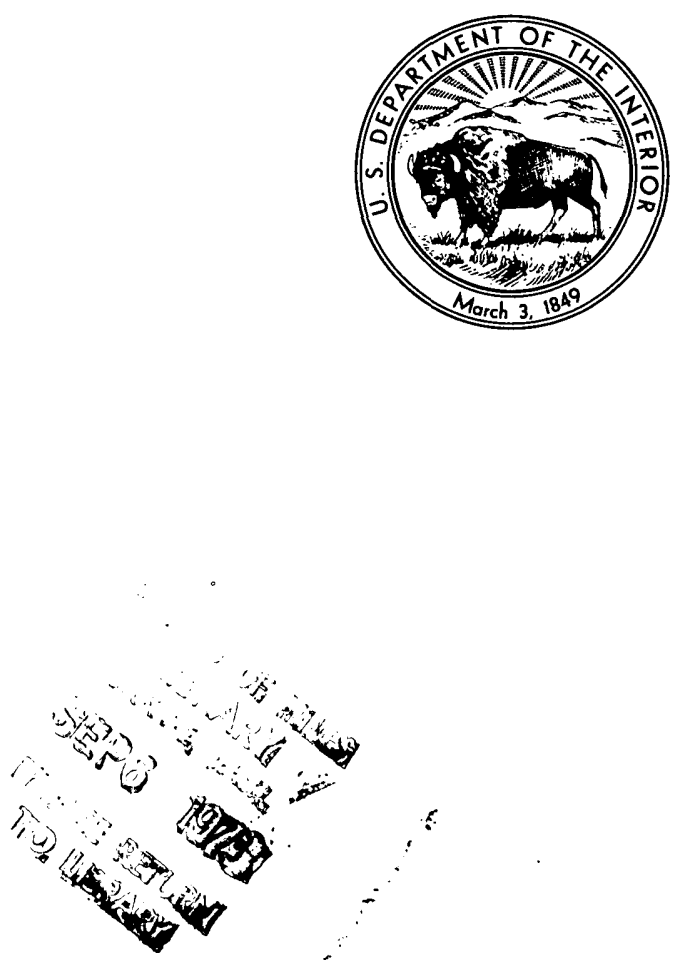
STRUCTURAL GEOLOGY OF THE SUN RIVER CANYON AND ADJACENT AREAS, NORTHWESTERN MONTANA 


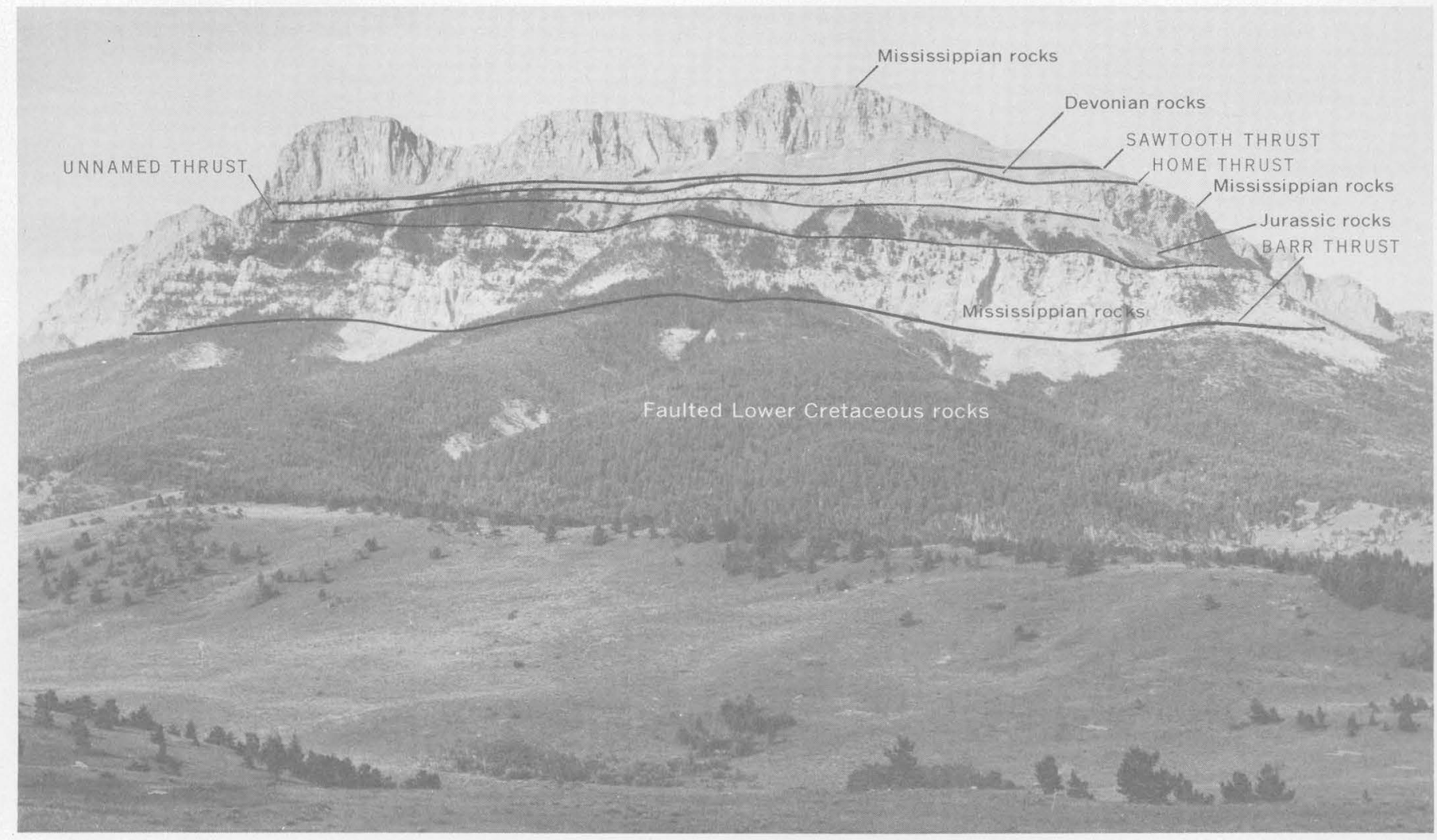

Stratigraphy and structure of the east face of Sawtooth Ridge. The tree- and grass-covered area in the foreground eontains thrust-faulted and folded Cretaceous rocks. 


\section{Structural Geology of}

the Sun River Canyon

and Adjacent Areas,

Northwestern Montana

By MELVILLE R. MUDGE

GEOLOGY OF THE SUN RIVER CANYON AREA, NORTHWESTERN MONTANA

GEOLOGICAL SURVEY PROFESIONAL PAPER 663-B

A comprehensive study of an area of

exceptionally well exposed thrust

faults and associated structures

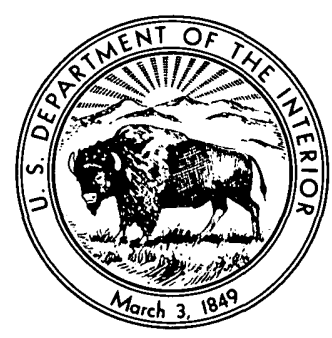

UNITED STATES GOVERNMENT PRINTING OFFICE, WASHINGTON : 1972 


\section{UNITED STATES DEPARTMENT OF THE INTERIOR}

ROGERS G. B. MORTON, Secretary

GEOLOGICAL SURVEY

V. E. McKelvey, Director

Library of Congress catalog-card No. 72-600066

For sale by the Superintendent of Documents, U.S. Government Printing Office

Washington, D.C. 20402 (paper cover)

Stock Number 2401-2080 


\section{CONTENTS}

Abstract

Introduction.

Previous studies

Accuracy of mapping and

(1)

Precambrian crystalline basement .............

General features of the structures...................

Subbelt I . . . . . . .

Subbelt II _. . . . . . . . .

Subbelt III . . . . . . . . . . . . .

Diversion and Deep Creek thrust blocks.......

Saw tooth thrust block ... . . . . . . . . . . . . . .

Allan thrust block . . . . . . . . . . . . . . . . .

Sheep Reef structures. . . . . .

Elk fault

Subbelt IV

Subbelt V..........

Pretty Prairie fault complex..............

Subbelt VI

Subbelt VII .

South Fork thrust zone

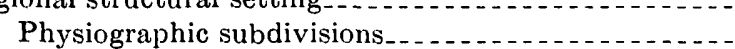

\begin{tabular}{|c|c|c|}
\hline $\begin{array}{r}\text { Page } \\
\text { B1 }\end{array}$ & $\begin{array}{l}\text { General features of the structures-Continued } \\
\text { Subbelt VII-Continued }\end{array}$ & $\mathrm{Pa}$ \\
\hline 2 & Longitudinal normal faults.......... & \\
\hline 2 & Subbelt VIII & \\
\hline 4 & Subbelt IX_... & \\
\hline 4 & Mechanies of thrusting and folding & \\
\hline 4 & Episodes of the orogeny & \\
\hline 4 & rs & \\
\hline 6 & ormation & \\
\hline 11 & Stratigraphic control & \\
\hline 11 & nits $_{\ldots}$ & \\
\hline 13 & Zones or horizons of weakness & \\
\hline 15 & rusting & \\
\hline 18 & Folding and initial thrust faulting & \\
\hline 19 & (n) & \\
\hline 19 & cate zones in Cretaceous rocks._._.... & \\
\hline 21 & (3-1, & \\
\hline 22 & ting & \\
\hline 22 & ter thrusting & \\
\hline 23 & lded thrust plates. & \\
\hline 23 & (n-1 & \\
\hline 23 & References cited & \\
\hline 27 & 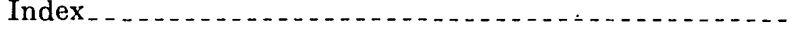 & \\
\hline
\end{tabular}

\section{L L US TR A T I O N S}

\section{[Plates are in pocket]}

Plate 1. Tectonic map of the Sun River Canyon area, northwestern Montana.

2. Generalized geologic structure in and adjacent to the Sun River Canyon area, Montana.

3. Geologic cross sections in the Sun River Canyon area, Montana.

4. Cross sections and palinspastic reconstruction of selected structures in the Sun River Canyon area, northwestern Montana.

5. Stratigraphic column for the Sun River Canyon area, Montana, showing the zones of weakness or horizons along which thrust faults occurred, and the thickness of the overburden above each horizon.

Frontispiece. Photograph showing stratigraphy and structure of the east face of Sawtooth Ridge.

FigURE 1. Map showing structural setting of the disturbed belt in northwestern Montana

2. Map showing physiographic subdivisions and structure in Montana

3. Isopach map of interval from the top of the Three Forks Formation to the top of the Cone Calcareous Member of the Marias River Shale.

4. Structure map of the Sweetgrass arch area, Montana.

5. Map showing subbelts of the disturbed belt in the Sun River Canyon area and the adjacent area to the east.-

6. Photograph showing Sun River anticline.

7. Photograph showing high-angle longitudinal normal faults in the western part of subbelt I

8. Photograph showing drag fold in the Vaughn Member of the Blackleaf Formation

9. Sections showing small folds in subbelt II

10. Section showing folded thrust plates. 
Figures 11-17. Photographs showing- Page

11. Eastern Sawtooth Range

12. North end of Diversion Ridge

13. Northward-plunging asymmetrical chevron fold in Devonian rocks

14. Overturned folds in the Devils Glen Dolomite (Cambrian) and Devonian strata

15. Flow folds in the incompetent Switchback Shale

16. The French thrust in a roadcut on the west side of French Gulch just south of the Sun River...

17. Wagner Basin and the south end of Castle Reef .

18. Diagram showing an interpretation of the development of the structure at the south end of Castle Reef _... 26

19. Photograph showing a double fenster in a large cirque on the west side of Sawtooth Ridge

20. Photograph showing ridge west of Big GGeorge Gulch and north of Gibson Reservoir

21. Photograph showing an asymmetrical chevron anticline at Beartop Mountain and an asymmetrical syncline in the valley

22. Diagram showing folded thrust plate in the Cone Calcareous and Ferdig Shale Members of the Marias River Shale . . . .

23. Diagram showing recumbent fold, small thrust, and two reverse thrusts in subbelt $V_{\ldots}$

24. Photograph showing folded thrust plate on north side of upper reaches of Bench Mark Creek

25. Photograph showing longitudinal normal fault in upper South Fork of Glenn Creek

26. Photograph of the crest of Slategoat Mountain

27. Photograph showing the crestal area of a tight overturned fold capped by a trachyandesite sill $\ldots$

28. Diagrammatic sections showing hypothetical development of most thrust faults in the Sun River Canyon

29. Map and sections showing an interpretation of the development of the South Fork thrust zone and associated

30. Diagrams illustrating stages in the formation of folded faults and back-limb thrust faults above the initial thrust

\section{TABLE}




\title{
STRUCTURAL GEOLOGY OF THE SUN RIVER CANYON AND ADJACENT AREAS, NORTHWESTERN MONTANA
}

\author{
By Melville R. Mudge
}

\section{ABSTRACT}

The Sun River Canyon area is a broad northerly trending imbricate fault zone about 20 miles wide with abundant westerly dipping thrust faults and some folds. The area lies along the east edge of the Cordilleran geosyncline, which was a sedimentary basin at various times during the last billion years.

The outcropping rocks thicken to the west. In the eastern part of the area, Paleozoic and Mesozoic rocks are about 10,700 feet thick; in the western part, about 16,200 feet thick. The inferred erosional edge of the Precambrian (Belt Supergroup) sedimentary rooks is just east of the area, whereas these rocks are more than 5,300 feet thick in the western part.

The Precambrian crystalline basement, although not believed to be broken by thrust faults, very likely affected the tectonic development of the early Tertiary structures. East of the Sun River Canyon area, the basement is structurally high in the northwest-plunging Sweetgrass arch. In and near the area, the northeasterly trending folds and lineaments probably. reflect structures in the basement. Near the east edge of the disturbed belt, the basement surface probably dips moderately westward from the craton into the geosyncline. Thus, it is assumed that the location and, in part, the nature of the deformation in the northern part of the disturbed belt were controlled by the east edge of the geosyncline and possibly also by the wedge edge of the Belt sedimentary rocks.

The uppermost crustal layer was shortened more than 29 miles in the Sun River Canyon area, as calculated from $9 y$ structures in a cross section $17 \frac{1}{2}$ miles long. The structures consist of 80 thrust faults, two longitudinal normal faults, and 17 sets of folds.

In the Sun River Canyon area, the disturbed belt is divisible into nine subbelts, each with its own structural and stratigraphic characteristics. The eastern two subbelts cover the part of the disturbed belt east of the mountains; four span the Sawtooth Range, and three are to the west in the Lewis and Clark Range. Subbelt I contains folded upper Cretaceous rocks and, in the western part, a few small thrust and longitudinal normal faults. Most folds are symmetrical; a few are asymmetrical. Subbelt II, mostly in Lower Cretaceous rocks, contains abundant closely spaced westerly dipping thrust faults and asymmetrical and overturned folds. The stratigraphic throw in most thrusts is less than 500 feet; in a few it is as much as 1,200 feet. Subbelt III characteristically has many large westerly dipping moderately high angle thrust faults that have stratigraphic throws ranging from 3,000 to 6,000 feet. Most fault blocks are composed
\end{abstract}

of Mississippian rocks overlain by Jurassic and Lower Cretaceous rocks; some also contain Cambrian and Devonian rocks. Asymmetrical and overturned folds and folded thrust plates are common. A longitudinal fault, downthrown toward the west, bounds subbelt III on the west. Its displacement ranges from 200 to about 600 feet. Subbelt IV, like subbelt I, contains folded Upper Cretaceous rocks and some small westerly dipping thrust faults. Subbelt V consists entirely of thrust-faulted and folded Lower Cretaceous rocks, like those of subbelt II. The stratigraphic throw of most of the faults is as much as 500 feet; for one, it is about 1,500 feet. Subbelt VI consists mostly of two large thrust blocks of Mississippian rocks overlain by Jurassic and Cretaceous rocks. Each large thrust, at the base of the Mississippian rocks, has a stratigraphic displacement of about 4,000 feet. The western block is overturned and is probably related to the exceptionally large thrust to the west in the South Fork thrust zone. Subbelt VII consists of a single thrust block of Precambrian and Paleozoic rocks. The largest thrust fault in the South Fork thrust zone, along the east edge of the subbelt, has a stratigraphic displacement of more than 14,000 feet and has had a minimum horizontal movement of 4 miles. The westerly dip of this fault ranges from $10^{\circ}$ to $60^{\circ}$. The largest longitudinal normal fault in the western part of the subbelt has a displacement of as much as 2,500 feet. Subbelts VIII and IX, like subbelt VII, consist of one fault block of Precambrian and Paleozoic rocks and one or more exceptionally large thrusts in the eastern part and longitudinal normal faults in the western part.

The thrust faults are strike, bedding, and back-limb types; some comprise an imbricate zone. Strike faults are most common; their fault surfaces dip somewhat more steeply than the overlying strata and somewhat less steeply than the underlying strata. Some of the large thrusts are locally bedding thrusts. Back-limb thrusts are also common on the back (west) limb of anticlines. Some thrust plates were folded during thrusting, and others after thrusting.

The sequence of deformation proceeded from east to west, according to all data on the Sun River Canyon and adjacent areas. Thus, the oldest structures are in the eastern part of the area.

Five episodes of orgeny are recognized; each episode had a compressional stress phase, and most were terminated by a tensional stress phase. The usual sequence of events in an episode was (1) folding stage, (2) thrust-faulting stage, and (3) longitudinal normal-faulting stage. 
Stress vectors from the west and southwest are reflected in the thrusts faults, folds, and trends of the structures. All thrusts dip to the west, and almost all folds parallel the trend of the thrusts. The axial planes of the asymmetrical folds are inclined to the west, with the steeper flank to the east.

The trends of the structures differ not only from south to north but also from east to west. South of the Sun River, the five most easterly subbelts trend mostly from $\mathrm{N} .10^{\circ} \mathrm{W}$. to $\mathrm{N}$. $20^{\circ} \mathrm{W}$., but north of the river they trend nearly due north. Both the Sun River and its West Fork are incised along structural flexures. South of the West Fork of the Sun River, the western four subbelts trend from N. $45^{\circ} \mathrm{W}$. to N. $80^{\circ} \mathrm{W}$, but north of that stream they trend from $\mathrm{N} .35^{\circ} \mathrm{W}$. to due north.

Factors that may control the response of a group of rocks to stress are the behavior of a unit or rock type, the zones or horizons of weakness, the mode of fracturing or shearing, the ability of rocks to flex or flow, and the amount of rock cover. The Precambrian strata may be undeformed because of two rigid units (Helena Dolomite and diorite sills) within them or because of the depth of fracturing or shearing that resulted in a thrust fault, the distance of translation of a fault block, and the angle of the fault. At least 11,000 feet, and locally as. much as 25,000 feet, of strata was above the zone of décollement in the Precambrian rocks at the time of fracturing. Massive even-bedded Paleozoic carbonates overlie a fault surface in many places. The overburden above the faults in these rocks ranges in thickness from 7,000 to 10,500 feet, but most is about 7,500 feet thick. The abundant closely spaced faults in Mesozoic rocks indicate that these rocks were brittle, especially in areas of severe stress. Faults in these younger rocks very likely took place under a maximum overburden of about 6,000 feet.

Many stratigraphic zones or horizons, mostly within or at the top of the mudstone units interbedded with sandstones or carbonates, are the loci of fractures and subsequent thrust faults. The most common locus is the base of the middle member of the Allan Mountain Limestone (Mississippian). Other principal horizons are in the Spokane Formation (Precambrian), the bases of various Cambrian limestone units, the lower part of the lower member of the Jefferson Formation (Devonian), the Rierdon Formation (Jurassic), the Kootenai Formation, and the Flood Shale Member of the Blackleaf Formation (Lower Cretaceous).

Some of the large thrust faults apparently developed on the east limbs of asymmetrical or overturned anticlines. Other thrusts formed independently of a fold. West of the initial thrust, subsequent (imbricate) faults formed higher on the limb and locally in the crestal area of the anticlines. Back-limb thrusts formed on the back limbs of the anticlines, mostly from the same stresses that formed the other faults within the anticline.

A thrust plate may fold during thrusting because of tilting of the fault surface. This depends partly on the nature of the strata traversed by the fault. A plate may fold after thrusting because of the advance of the next younger thrust fault during the same orogeny or because of underthrusting. Regional folding during a later orogeny does not appear likely.

The structures in the northern part, of the disturbed belt very likely resulted from compression during gravitational gliding from a more westerly vertically uplifted area.

The orogeny responsible for the disturbed belt in northwestern Montana was no earlier than very late Cretaceous and no later than late Eocene; most probably it was Paleocene to late Eocene.

Easterly trending normal faults, some of which may be tear faults, displace some thrusts. They do not exceed 100 feet in displacement.

\section{INTRODUCTION}

The Sun River Canyon area lies astride the center of the northern part of the Montana disturbed belt and extends about 19 miles eastward and about 18 miles northward. It is characterized by abundant closely spaced thrust faults that form a broad imbricate zone (pl. 2; fig. 1). There are good to excellent exposures over much of the area and as much as 4,000 feet of relief; detailed mapping has resulted in a much better understanding of the mechanics of folding and thrusting in this classic example of a thrust belt. The stratigraphy of the area is described in chapter $\mathbf{A}$ of this professional paper series (Mudge, 1972), and the general geology of six $71 / 2$-minute quadrangles has been mapped (Mudge $1965 \mathrm{a} ; 1966 \mathrm{a}, \mathrm{b}, \mathrm{c} ; 1967 ; 1968)$.

The northern part of the "disturbed belt" of Montana, as the term is used herein, is an area of intense deformation that extends from the South Fork of the Flathead River east nearly to Augusta, Mont. (fig. 2). The east edge of the belt trends northwesterly from a point about 1 mile west of Augusta. This is the east limit of the disturbed belt as defined by Stebinger (1918) and Alpha (1955b, p. 137). They, however, defined the west edge of the belt as the mountain front, whereas I include most of the mountains also. The disturbed belt as a whole extends from southwestern Montana northwest through Alberta and northern British Columbia.

The assistance given me in the field and office by many colleagues and friends is acknowledged in chapter A of this professional paper series (Mudge, 1972). Here, I specifically wish to thank A. B. Griggs and James Gilluly for their critical review of this manuscript.

\section{PREVIOUS STUDIES}

Previous studies of this and adjacent areas are summarized in chapter A of this professional paper series (Mudge, 1972), but only a few discuss the structure of the area. Early regional reconnaissance studies of northwestern Montana were made by Chapman (1900), Bevan (1929), and Clapp (1932). Some of the anticlines-those in the plains east of the mountainswere described by Stebinger $(1917,1918)$. The studies most pertinent to the structural interpretation of the Sawtooth Range were made by Deiss (1943a, b). His unpublished reconnaissance maps of the Ovando, Coopers Lake, Saypo, and Silvertip quadrangles (scale $1: 125,000)$ were available to me. Part of Deiss' map of the Silvertip quadrangle was also used in a study by Johns (1964). The Marias Pass area, which encompasses the southern end of Glacier National Park, was studied by Childers (1963). Some of the structure of the south- 


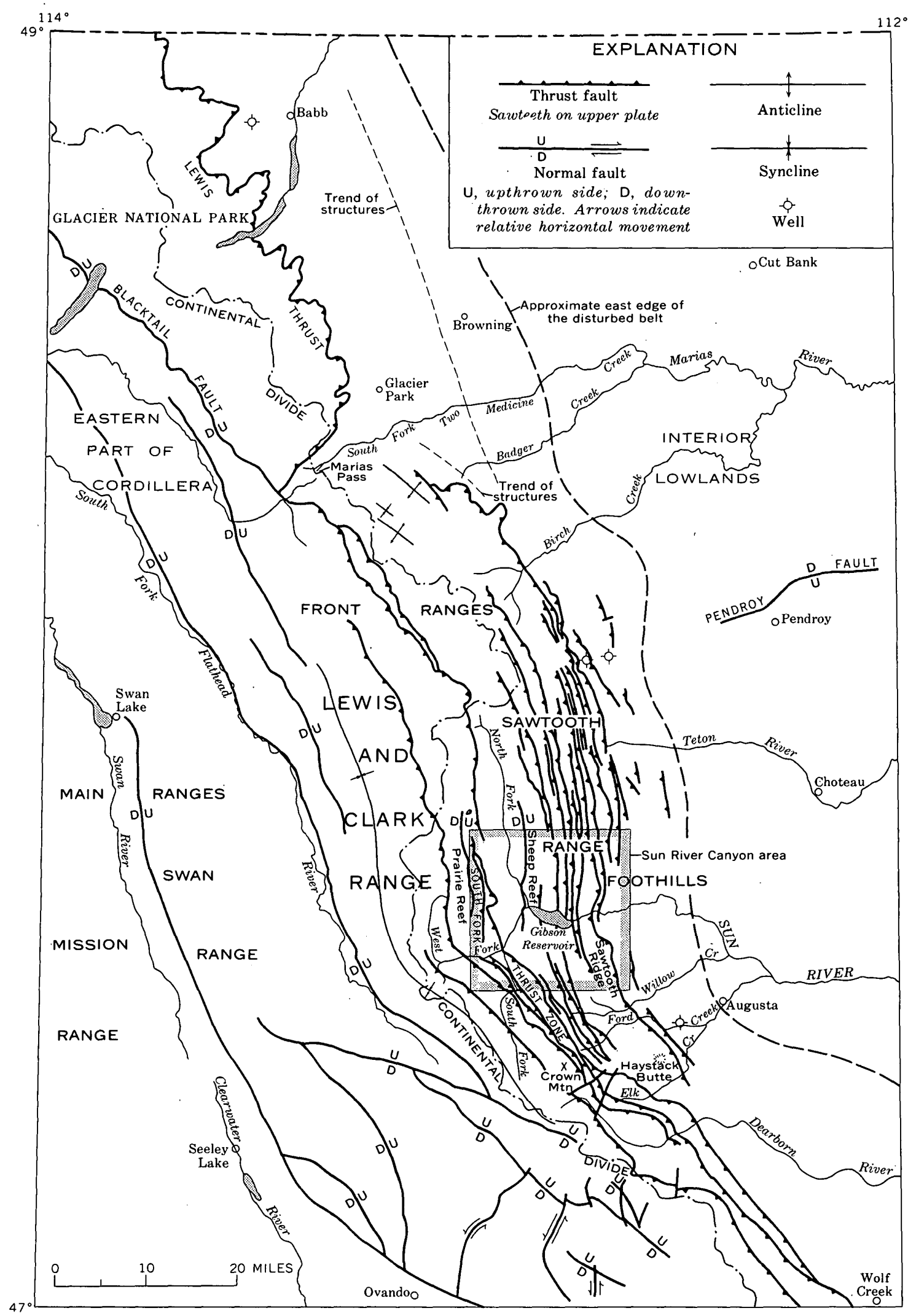

Figure 1.-Structural setting of the disturbed belt in nortnwestern Montana. 
eastern part of the Lewis and Clark Range was summarized by Mudge, Erickson, and Kleinkopf (1968). Six quadrangles of the Sun River Canyon area were mapped by me (Mudge, 1965a; 1966a, b, c; 1967; 1968), and the origin of the disturbed belt of northwestern Montana and its extension into Alberta and British Columbia were discussed by me (Mudge, 1970).

Nearby areas that have been covered by theses studies are the Dearborn River area (Viele, 1960), the Elk Creek area (Holcombe, 1964), the southern terminus of the Sawtooth Range (Merrill, 1965), and the upper reaches of the South Fork of the Flathead River (Sommers, 1966).

\section{ACCURACY OF MAPPING AND STRUCTURAL INTERPRETATIONS}

The stratigraphy and structure of the Sun River Canyon area are well exposed, especially along all mountain ridges. The valleys, although mostly mantled with thin Quaternary deposits, do contain many isolated bedrock exposures. Most major streams and many tributaries are incised in bedrock.

Geologic data were plotted in the field on preliminary topographic maps at a scale of 1:20,000. Location and placement of most geologic contacts and faults on the map were by the resection method, using a lightweight tripod, planetable, and open-sight alidade. Aerial photographs, at the same scale as the maps, were used in the field for location, interpretation of geology, planning of traverses, and plotting of surficial geology. Mapping of members and small individual lithologic units, such as sandstone beds, and recognition of subdivisions of members and faunal zones were used for structural interpretations.

The lines of the geologic section are shown on plate 1 of this report; other geologic data are shown on plate 1 of chapter A (Mudge, 1972) and on the published quadrangle maps (Mudge, 1965a; 1966a, b, c; 1967; 1968). Near the surface, the sections show the same detail as plate 1 of chapter $A$. The projections at depth shown in sections $A-A^{\prime}$ and $B-B^{\prime}$ on plate 3 are based on the regional habit of the structures. No attempt was made on plate 3 to compensate for thickening and thinning as a result of flowage, folding, and imbricate faulting in the subsurface. The uncertainties and error naturally increase markedly with depth. The eastern, little-deformed part of the sections is controlled by both outcrop data and logs of wells to the east. The western part of the sections is controlled entirely by surface data and the extrapolation of the westward thickening of all strata thereby shown.

\section{STRATIGRAPHY}

The stratigraphy of the Sun River Canyon area is described in detail in chapter A (Mudge, 1972); only a summary is presented here in table 1 . The preQuaternary rocks form a sequence of largely incompetent strata interbedded with some competent units, which greatly influenced and, in many places, controlled the development of structures. The physical and compositional features that may have affected the evolution of the geologic structure are discussed in the following paragraphs.

A notable change in thickness from east to west across the tectonic strike is evident in most formations. (Mudge, 1972). The Paleozoic and Mesozoic rocks are about 10,700 feet thick in the east and about 16,200 feet thick in the west. The Precambrian Belt rocks also thicken markedly westward from about 5,300-7,500 feet in the east to about 25,000 feet in the west.

Many units change in facies from east to west. The Steamboat Limestone has equal amounts of limestone and mudstone in the east but is mostly limestone in the west. The breccia in the Three Forks Formation is about 50 feet thick in the east but thickens to about 600 feet in the west. The Morrison Formation and the Ferdig Shale Member and the upper part of the Kevin Shale Member of the Marias River Shale are mostly mudstone in the east but chiefly sandstone in the west.

Unconformities exist at several positions in the stratigraphic sequence in the Sun River Canyon area (table 1). The disconformity at the base of the Middle Cambrian Flathead Sandstone very likely had an indirect but important role in the structural development. This sandstone overlies an erosional surface at which successively older Belt strata had been truncated to the east (Mudge, 1972). The erosional edge of the Belt therefore must lie a short distance east of the mountain front. The edge of the Belt strata virtually coincides with the approximate edge of the disturbed belt, as discussed later in the present report.

\section{REGIONAL STRUCTURAL SETTING PHYSIOGRAPHIC SUBDIVISIONS}

The study region (figs. 1,2 ) is in the eastern part of the northern Cordillera and western part of the Interior Lowlands (King, 1959, pl. 1). The eastern part of the Cordillera in the study region contains the Foothills on the east, the Front Ranges, and the Main Ranges on the west. The Foothills and the Front Ranges compose the disturbed belt. The same provinces extend into Alberta, Canada, where a similar geologic environment was described by North and Henderson (1954) and by Bally, Gordy, and Stewart (1966). Only three of the eight subdivisions of the Cordillera listed by Bally, Gordy, and 
STRUCTURAL GEOLOGY

TABLE 1.-Stratigraphy of the Sun River Canyon area

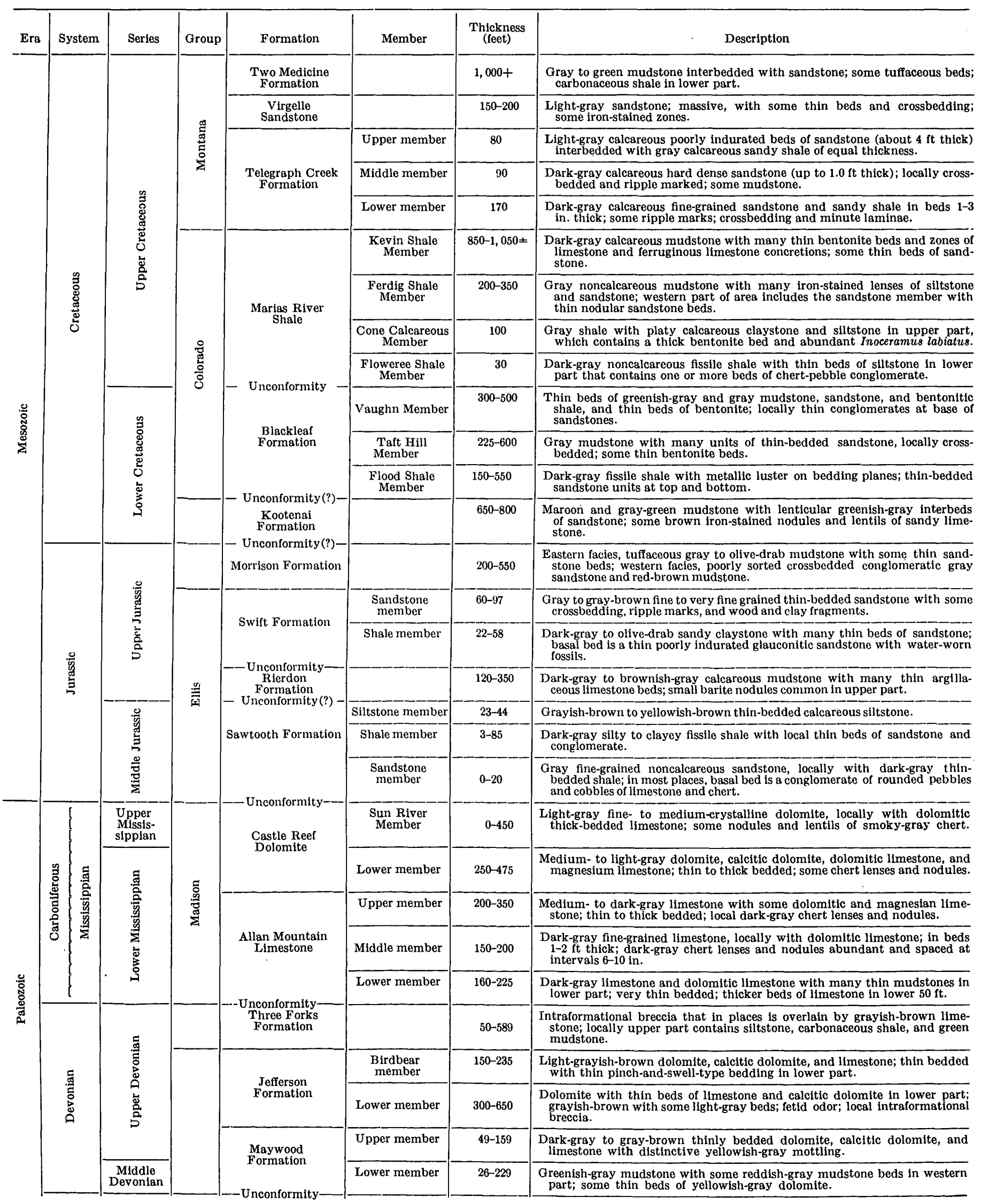


$\mathrm{T}_{\mathrm{ABLF}}$ 1.-Stratigraphy of the Sun River Canyon area-Continued

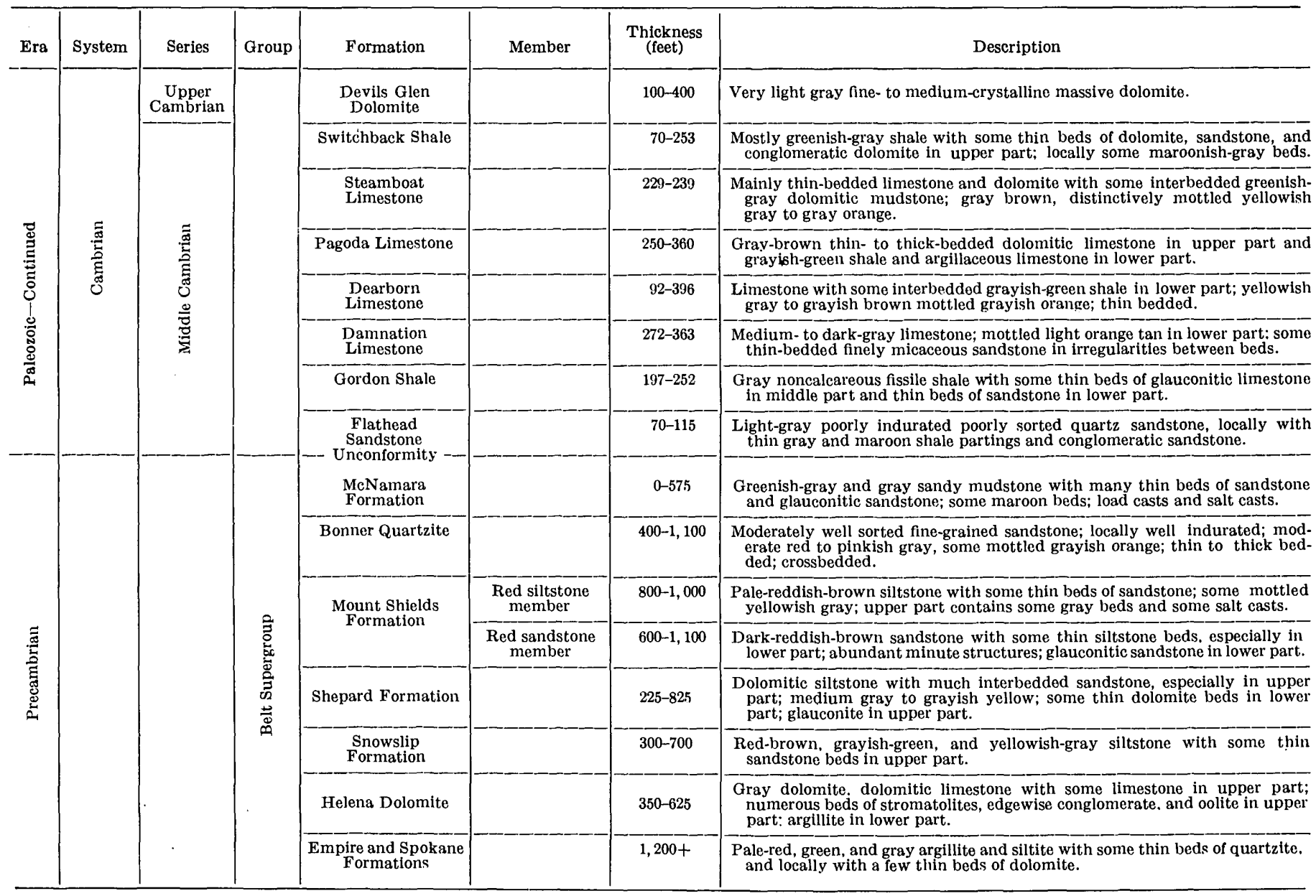

Stewart (p. 342-345) are discussed here. Their Interior Plains subdivision is included herein as the Interior Lowlands (figs. 1, 2).

The geology differs from one subdivision to another. In the plains, the western Interior Lowlands contain several large broad open folds, exemplified by the Sweetgrass arch and the Little and Big Belt uplifts (fig. 2); which involve rocks including the Precambrian basement-the pre-Belt crystalline rocks. The northeast-trending Pendroy normal fault and most of the Scapegoat-Bannatyne trend are in this region (Dobbin and Erdmann, 1955). The Foothills subdivision comprises the area between the mountain front and the plain; it forms the eastern part of the disturbed belt and is characterized by broad open symmetrical folds to the east and abundant closely spaced high-angle thrust faults to the west. Throughout the Foothills subdivision, Cretaceous rocks are exposed. The Front Ranges of the Cordillera are made up of the Sawtooth Range and the Lewis and Clark Range. The eastern part contains many highangle thrust faults that transported Paleozoic rocks onto
Lower Cretaceous rocks. The central part contains many thrust faults and folds and a longitudinal normal fault. These are mostly in Cretaceous rocks and partly in Mississippian and Jurassic rocks. The western part of the Front Ranges has widely spaced exceptionally large thrust faults and some open folds in Precambrian (Belt) and Paleozoic rocks. In Glacier National Park to the north, the western part of the Front Ranges contains the Lewis thrust fault (fig. 1), which placed Precambrian (Belt) rocks on Cretaceous strata that underlie the eastern and middle parts of the subdivision. The Main Ranges are made up of the Swan and Mission Ranges. This subdivision characteristically contains exceptionally large longitudinal normal faults (basin and range type) and Precambrian Belt rocks.

\section{PRECAMBRIAN CRYSTALLINE BASEMENT}

Precambrian crystalline rocks (basement), although possibly not broken by thrust faults, very likely affected the tectonic development of the structures. Chamberlin (1945, p. 99) noted that: 
The more these mountains are studied, the more it becomes evident that preexisting structures in the underlying basement rocks, developed long before our present Rockies started to form in Laramide times, have had great influence in determining the areal pattern of some of the present ranges and basins and likewise the modes of yielding under the compressive stresses.

Folds and faults in the basement were major controls in the development of structures in some areas but had little influence on others (Chamberlin, 1945, p. 99). Seismic data in the southern Canadian Rocky Mountains indicate that the Precambrian crystalline basement dips gently westward from the Canadian Shield (Bally and others, 1966, p. 342; Flawn, 1967). In Montana, however, folds and possibly faults are present in the basement.

The Precambrian crystalline rocks are not exposed in and near the Sun River Canyon area, but they are visible in the Little Belt Mountains, about 90 miles to the southeast. These rocks are gneiss and schist, locally intruded by diorite (W.R. Keefer, oral commun., 1967). On the Sweetgrass arch, east and northeast of Choteau, at least seven wells have penetrated Precambrian crystalline and igneous rocks. Many other wells extend to various horizons in Paleozoic rocks. Data from these wells, combined with other stratigraphic data, provide information on the tectonic framework of the region.

The regional tectonic framework was established in late Precambrian time and persisted, with some vari- ations, throughout much of the Paleozoic (Sloss, 1950, p. 430) and Mesozoic. The structures that formed during late Precambrian time were the Cordilleran geosyncline in western Montana, a craton in north-central Montana containing the Sweetgrass arch, and, south of the craton, the central Montana trough (Sloss, 1950, p. 426-427).

The area of the Precambrian Cordilleran geosyncline was a basin of deposition throughout much of geologic time. Part of the area was a miogeosyncline during Cambrian, Devonian, and Mississippian time. The eastern part of the Cordillera was a narrow northerly trending basin or trough during much of Mesozoic time.

A relatively sharp break separates the craton on the east and the geosyncline on the west. This break occurs just east of the Sun River Canyon area, as indicated by marked thickening of strata westivard from the craton area (fig. 3). The erosional edge of the Belt rocks as shown by Sloss (1950, fig. 3, p. 429) is near the east edge of the disturbed belt. Although individual formations of the Belt Supergroup thin markedly to the east, the present east edge of the supergroup is very likely erosional. The Sweetgrass arch was uplifted after Belt sedimentation, and Belt strata were truncated before the Middle Cambrian (Deiss, 1935, pl. 8; Mudge, 1970).

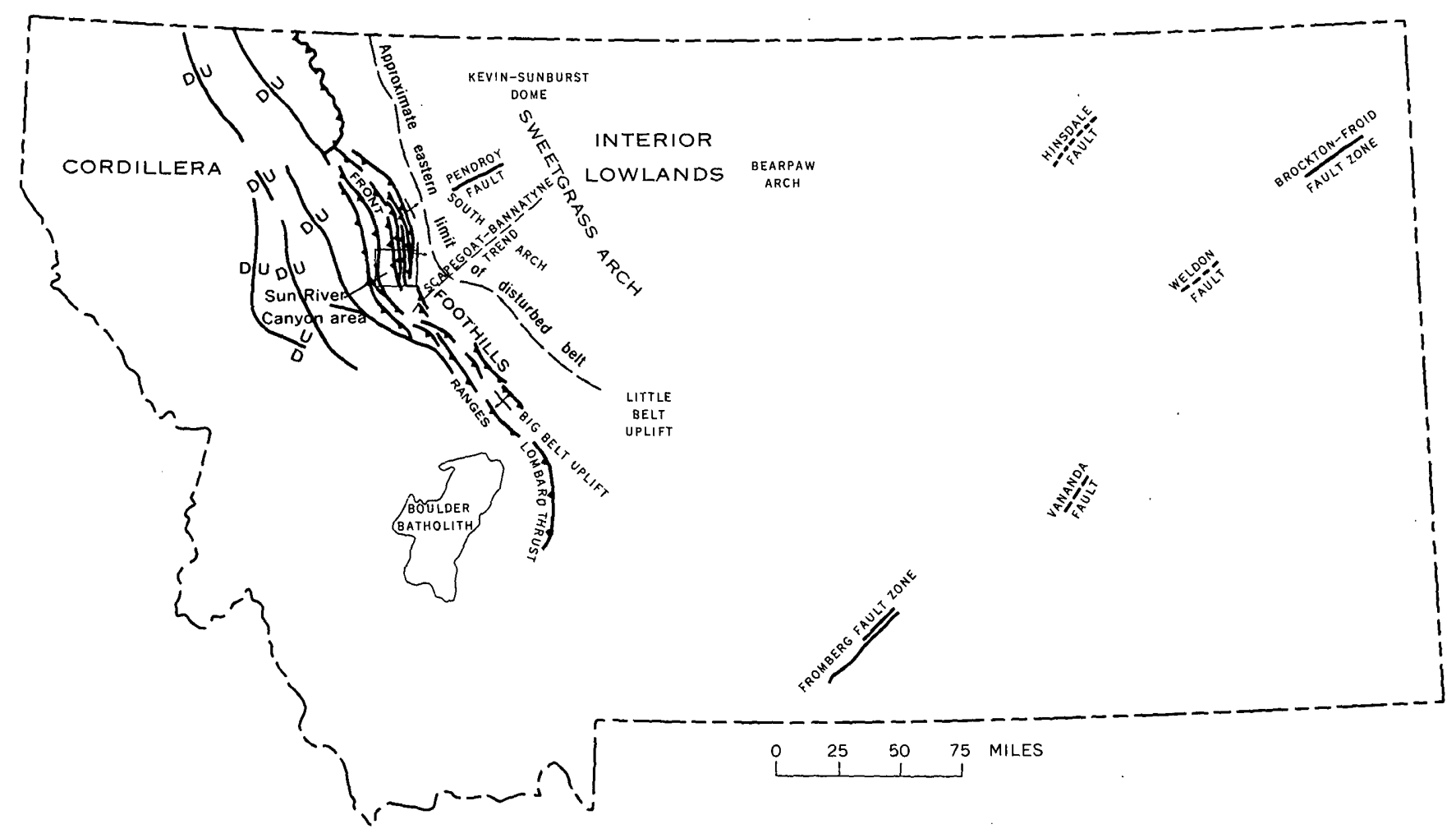

Figure 2.-Some structures and physiographic subdivisions in Montana. 


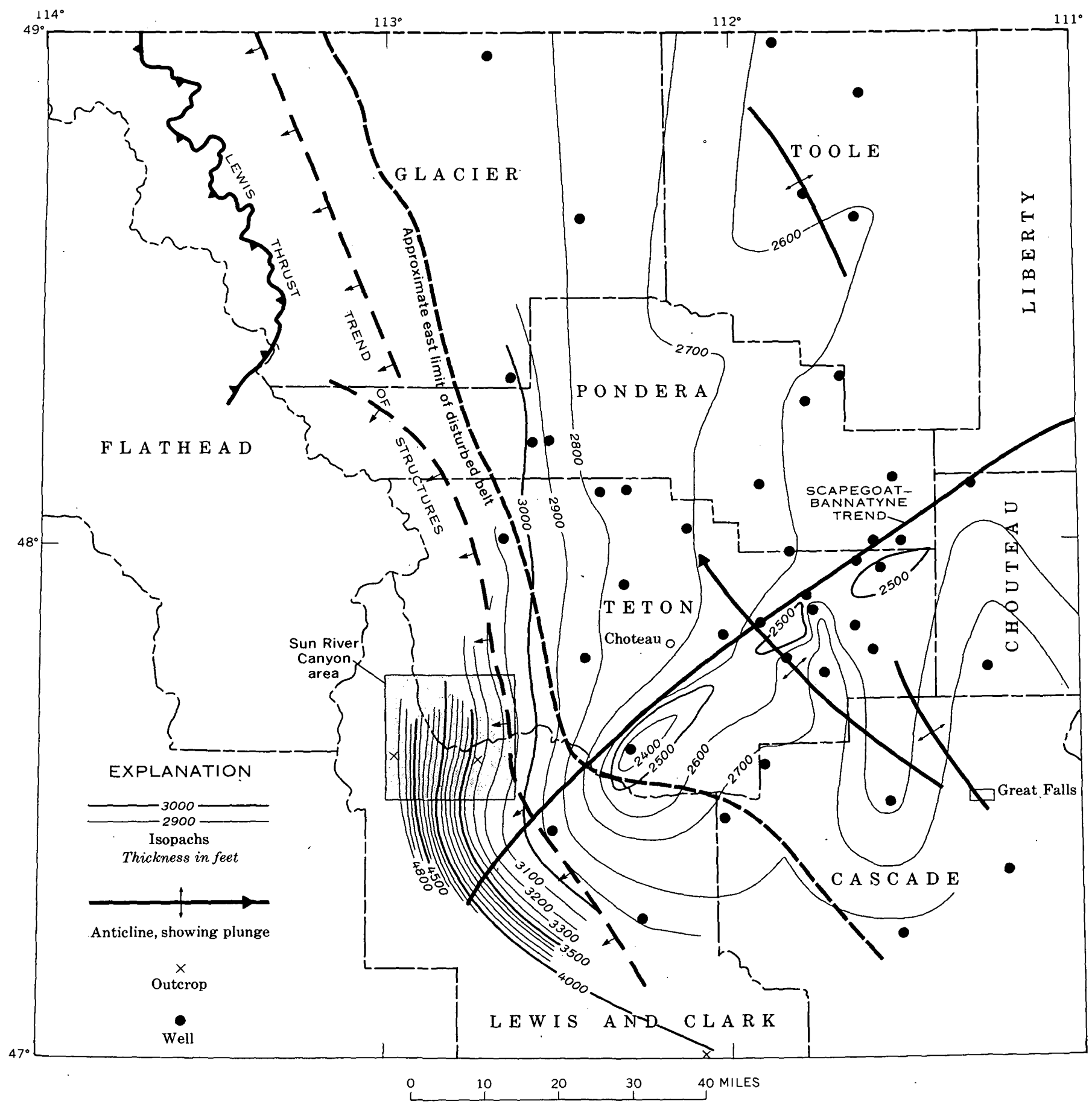

Figure 3.-Isopach map of interval from the top of the Three Forks Formation to the top of the Cone Calcareous Member of the Marias River Shale.

The Sweetgrass arch is a broad northwest-plunging flexure that contains the south arch and the KevinSunburst dome (Alpha, 1955b, p. 138; Dobbin and Erdmann, 1955). The Sweetgrass arch was active tectonically at various times from the Precambrian on, attaining its present position and configuration near the end of the Cretaceous (fig. 4).

The highest known point on the basement in the Sweetgrass arch area is 514 feet above sea level; from it, the surface of the crystalline rocks dips gently northeastward and steeply southwestward. The northwest end of the south arch, near Choteau and the Pendroy fault, bulges westward (Dobbin and Erdmann, 1955), indicating a possible westerly to northwesterly plunging ridge on the basement surface. West of the south arch, Stebinger (1918, pl. 24) showed a low broad northerly trending syncline extending in to Alberta. From the edge of the craton, the basement surface is assumed to dip 


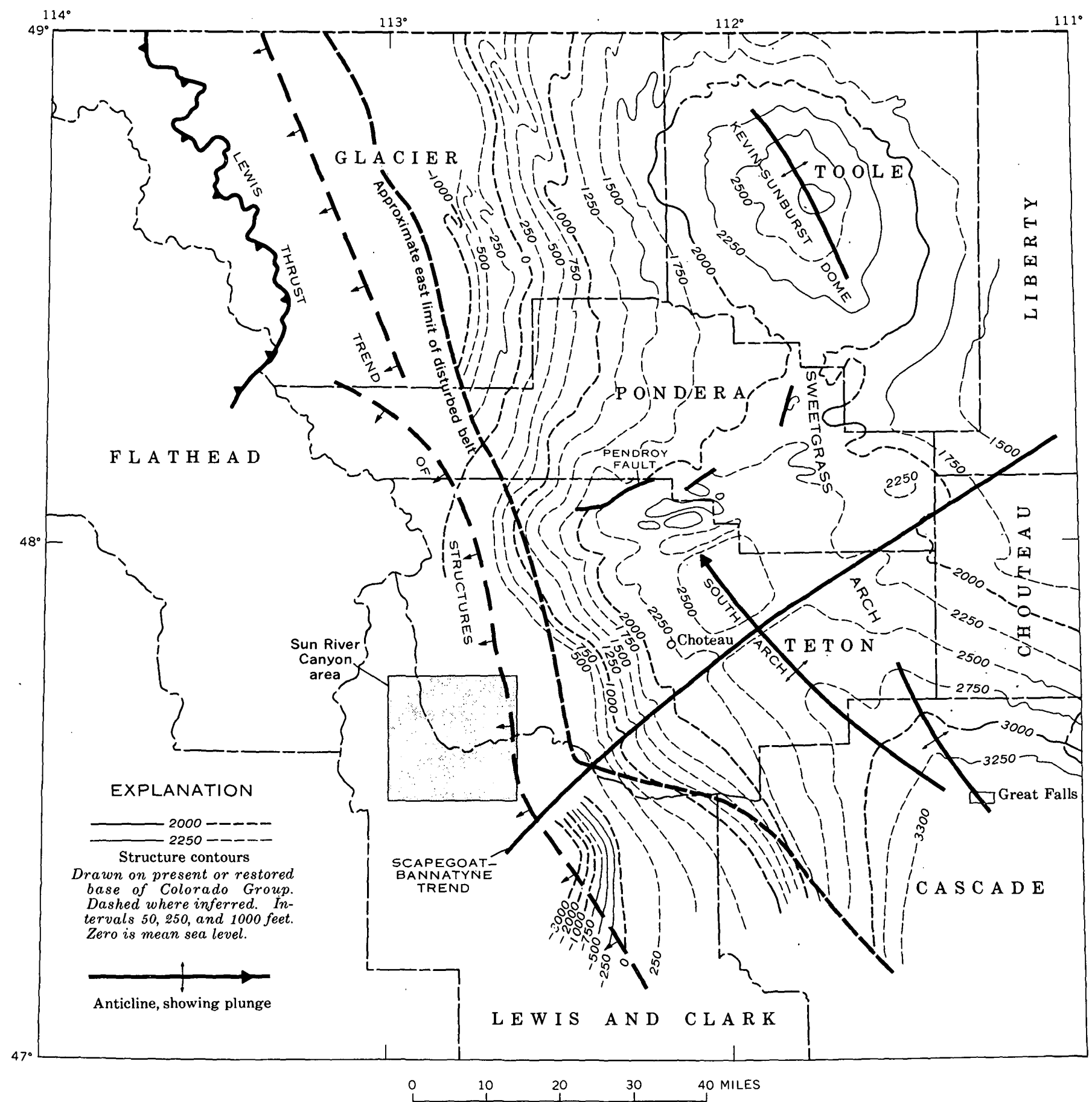

Fraure 4.- Structure map of the Sweetgrass arch area, Montana. Adapted from Dobbin and Erdman (1955).

moderately westward, possibly with some small irregularities.

The Scapegoat-Bannatyne trend (fig. 2) is a group of structural anomalies extending southwest across the Sweetgrass arch into a transverse fault zone in the southeastern part of the Lewis and Clark Range (Dobbin and Erdmann, 1955). The transverse faults displace thrust faults. The anomalies originated prior to the Middle Cambrian and were rejuvenated at various later times (Alpha, 1955a, p. 133-134). Alpha noted that the trend parallels the structural grain of pre-Paleozoic and early Paleozoic features of the Canadian Shield in Canada and Minnesota. On the south arch of the Sweetgrass arch, some structurally high areas of the Precambrian surface along the ScapegoatBannatyne trend have a relief of more than 1,400 feet (Alpha, 1955a, p. 133). Cambrian and basal Devonian strata wedge out against them.

Northeastern structural trends, common in Alberta and Montana, probably reflect structures of the Pre- 
cambrian basement, as do northeast-trending faults in the northern part of Alberta (Flawn, 1967). Easterly trending folds younger than the thrust faults in Alberta are described by Hume (1941, p. 92). Alpha (1955a, p. 133) noted that in Montana the Bearpaw arch, the Weldon fault, the Fromberg fault zone, and the general axis of the Boulder batholith trend northeast (fig. 2). Other northeast-trending structures are the Pendroy (figs. 2, 4), the Brockton-Froid fault zone, the Hinsdale fault, and the Vananda fault (Cohee, 1961). The Pendroy fault displaces Upper Cretaceous rocks and may represent renewed movement on an older fault.

Easterly trending folds in the basement are also indicated by the structural pattern of some of the thrust plates in the Sawtooth Range in this area. Longitudinal sections across the Sawtooth, Castle Reef, Arsenic Peak, and Patricks Basin quadrangles (Mudge, 1965a, 1966a, 1967, 1968) show easterly trending broad open anticlines, synclines, and small monoclines. One monocline trends east from a point about half a mile south of Gibson Reservoir past the north end of Sawtooth Ridge. Along this trend, the geologic maps show abrupt changes of structure in many fault blocks, perhaps reflecting a preexisting basement structure (Mudge, $1965 \mathrm{a}, 1966 \mathrm{a})$; however, these changes of structure may, of course, be due to buried irregularities in some thrust plates or to post-early Tertiary uplift.

The early Tertiary folds and faults plunge mostly northwestward and southeastward from the central part of the Sawtooth Range. At the south end of Glacier National Park, near Marias Pass, the Lewis thrust forms a reentrant to the west (fig. 1). There the con-. figuration of the thrust plate, although much altered by erosion, reflects an original salient in the base of the allochthon (Childers, 1963, p. 160). There the Lewis thrust is at an elevation between 6,000 and 7,000 feet (Ross, 1959, pl. 2). Southeast of the salient, in the northern Sawtooth Range, the northwest-plunging folds expose Mississippian rocks in the cores of the anticlines at elevations of more than 8,000 feet. Before erosion, the Lewis thrust block probably extended over at least part of this range. If so and if there has been no later deformation, the Lewis thrust block in Glacier National Park traveled through a structurally low area.

The relationship between the disturbed belt in the Sun River Canyon area and the craton (pls. 2, 3) is the same as that noted in southeastern Idaho by Staatz and Albee (1966, p. 93), who stated: "The craton east of the geosyncline formed a fairly stable buttress against which northeastward-acting forces formed a series of fairly closely spaced thrust faults."
In the Sun River Canyon area, the forces were directed mostly in an easterly direction; however, both south and north they were directed mainly northeasterly.

The east edge of the disturbed belt in the Sun River Canyon area is ideally located for the development of asymmetrical folds from compressive stresses. As noted above, all the strata from the Belt Supergroup up thin toward the edge of the craton, and this boundary closely agrees with the plainward boundary of the disturbed belt; they are almost surely related phenomena. According to de Sitter (1956, p. 239):

When a sedimentary series wedges-out toward the basin border, and later compression originates a concentric fold in this thinning portion of the basin margin, the two flanks of this structure are no longer equal; the sedimentary series of the flank nearest the basin border are thinner than those of the opposite flank. As the radius of curvature is a direct consequence of the thickness of sedimentary series involved in the folding, the flank facing the border will have a shorter radius and will therefore be steeper than the opposite flank.

In this mechanism, the basement itself, is not involved in the folding.

The easterly acting stresses produced the most intense deformation in the central Sawtooth Range west of Choteau (Deiss, 1943b, p. 1160). Deiss noted that the fault blocks in that area dip at higher angles and are more closely spaced than elsewhere. The fault blocks plunge to the northwest (Childers, 1963, p. 154) and to the south. The structures along the Pendroy fault and the westerly bulge of the structure contours at the rorthwest end of the south arch of the Sweetgrass arch also approach the central part of the range (fig. 4). If the bulge represents a westerly plunging fold in the Precambrian basement, it may have been a formidable buttress that opposed the easterly acting early Tertiary forces and thereby caused the thrust-fault plates to pile onto the steeper parts of the barrier.

The fault blocks plunge to the southeast in the southern. Sawtooth Range. South of this area; at the south end of the range; the fault blocks of Paleozoic rocks plunge southeastward. The structures change notably near Willow and Ford Creeks, 2-6 miles south of the Sun River Canyon area (fig. 1). In the Willow Creek area, undisturbed Mississippian rocks are at a depth of about 8,900 feet, as recorded by the American Stratigraphic Co. (log M471) in a drill hole in the center of the SW $1 / 4 \mathrm{SW} 1 / 4$ sec. $32, \mathrm{~T} .20 \mathrm{~N}$., R. 7 W. (Pan American-Gulf Gelsinger 1). Many 
thrust faults were recorded in this log above a depth of 5,100 feet. In comparison, a few miles east of Sun River Canyon, undisturbed Mississippian rocks were computed to be at a depth of about 4,300 feet, which suggests that the area south and southeast of the Sawtooth Range is structurally low and basement controlled.

\section{GENERAL FEATURES OF THE STRUCTURES}

The Sun River Canyon area is a broad imbricate zone with abundant westerly dipping thrust faults and some folds (pls. 1,2) that trend north to northwest parallel to the regional strike. Most thrust faults moved older rocks onto younger, but a few thrust younger rocks onto older. In general, the fault dips change progressively from high angle in the east to low angle in the west (pl. 2).

Folding took place before, during, and after the thrusting. Open symmetrical folds are more common in the easternmost part of the disturbed belt; closed asymmetrical and overturned folds are characteristic elsewhere. Tight asymmetrical chevron folds are mostly restricted to Mississippian rocks, and more open asymmetrical or symmetrical folds are commonly in Cretaceous rocks. Thrust faults are closer to the axial planes of folds in Mississippian rocks than in Mesozoic rocks.

The lateral shortening can only be approximated, inasmuch as erosion has removed an unknown amount of the eastern part of each thrust block. A minimum of 29 miles of shortening was calculated for the stratified sequence in the Sun River Canyon area. This calculation is based upon an east-west section $171 / 2$ miles long that intersects 80 thrust faults, two longitudinal normal faults, and 17 sets of folds. This calculation is considered conservative, as many small thrust faults, although recognized, were not mapped, and the lengths of the eroded east margins of the fault blocks were not considered. This shortening of the shallow strata is about 62 percent, which is slightly more than the conservative figure of 50-percent reduction for the same belt in Alberta, estimated by North and Henderson (1954, p. 78). For that area, similar amounts of lateral shortening were postulated by Shaw (1963, p. 238) and Bally, Gordy, and Stewart (1966, p. 359). In the Boule and Bosche Ranges in Alberta, O'Brien (1960, p. 426) listed about 23 miles of shortening by folding and faulting, which also represents a reduction of 50 percent. The aggregate vertical displacement of all structures in the Sun River Canyon area is more than 26 miles; the stratigraphic throw averages about half the horizontal movement.

The disturbed belt is divisible into nine subbelts in the Sun River Canyon area (fig. 5), following a scheme originated by Deiss (1943b, p. 1147). The term "subbelt" is preferred to "zone," "unit," or "province" because "subbelt" suggests a linear unit and does not conflict with accepted geologic usages of "zone," "unit," or "province."

The subbelts are distinguishable by such features as the lithologic units involved, the intensity of deformation and the attitudes of faults. The subbelts recognized are found elsewhere in the disturbed belt of Montana. They vary along strike, and in places two or more subbelts may blend. Reconnaissance in northwestern Montana confirms the existence of the three major tectonic units mentioned by Childers (1963, p. 154). His easternmost unit is the part east of the mountains, including subbelts I and II of the present report. His central unit spans the Sawtooth Range, including subbelts III, IV, V, and VI of the present report; and his western unit covers the Lewis and Clark Range and subbelts VII, VIII, and IX of the present report (fig. 5). To the north, in the Two Medicine-Badger Creek area, Weimer (1955, p. 146) listed five zones across the disturbed belt, which also correlate with the subbelts in this area.

\section{SUBBELT I}

Subbelt I, about 7 miles wide, is bounded on the east by the approximately located east boundary of the disturbed belt (fig. 5). In the Sun River Canyon area, subbelt I was referred to as the eastern structural area (Mudge, 1959, p. 21). It contains folded Upper Cretaceous rocks and, in its western part, a few small thrust faults. This subbelt is equivalent to the eastern structural unit described by Stebinger $(1918$, p. 168) for the Birch Creek-Sun River area. It is also equivalent to zone 1 described by Weimer $(1955$, p. 146) in the Two Medicine-Badger Creek area (fig. 1) to the north, where the subbelt is also characterized by folded Upper Cretaceous rocks, but with thrust faults, mainly along the east flank of each anticline (Weimer, 1955, pl. 1).

Because most of subbelt I lies east of the Sun River Canyon area, the boundaries shown in figure 5 were determined mostly from reconnaissance traverses along the Sun River and Willow Creek. The data on the central and eastern parts of the Deep Creek area are from Stebinger (1918, pl. 24).

The structural trend in this subbelt, north of the Sun River, is almost due north, whereas south of the river it changes to about $\mathrm{N} .10^{\circ} \mathrm{W}$.

The northerly trending folds are narrow elongate open synclines and anticlines, most with both limbs dipping at moderately low angles. Some are asymmetrical with the east limbs of anticlines somewhat steeper than the west limbs; the Sun River anticline (fig. 6) is an example of this type of fold (Billings Geological 


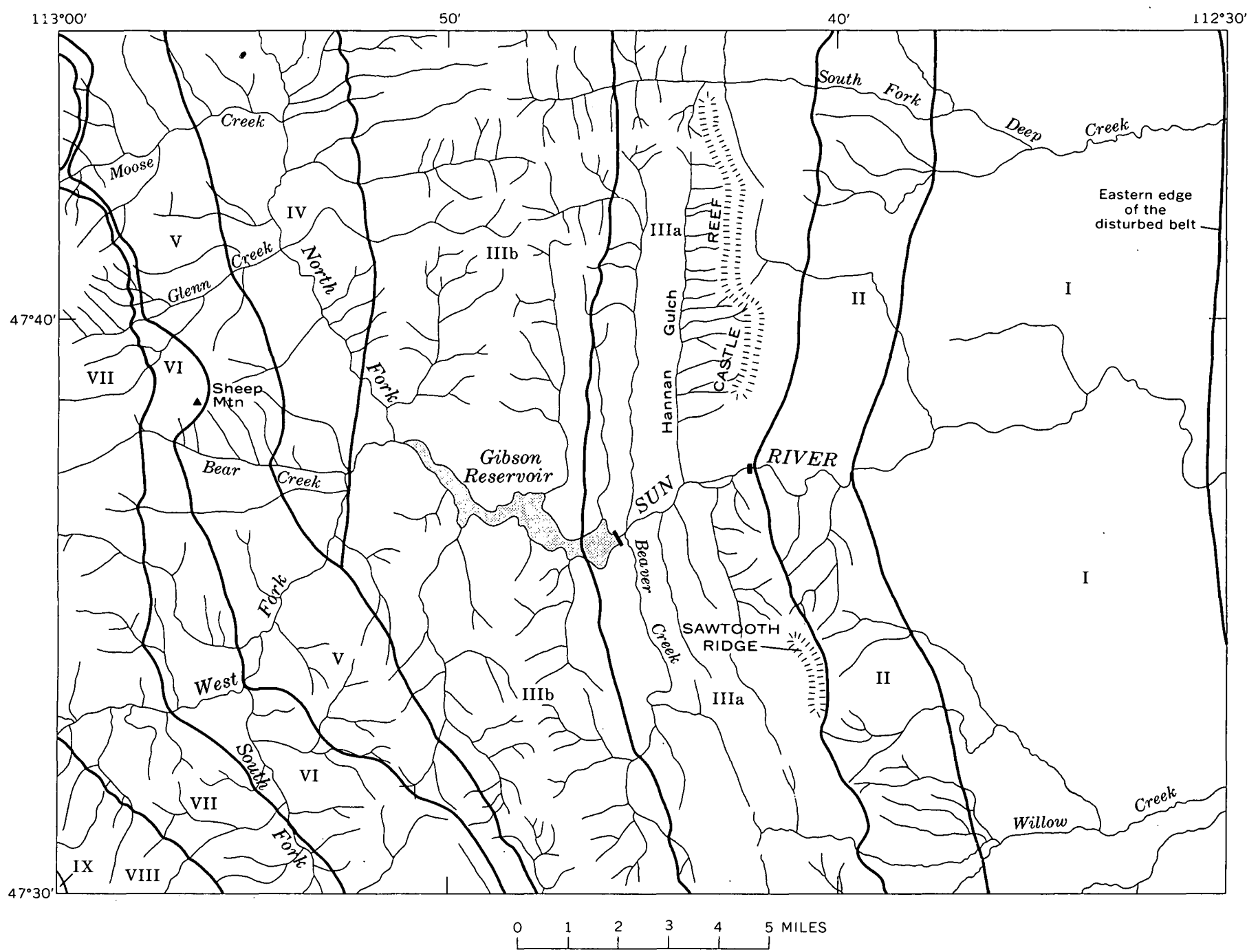

Frgure 5.-Subbelts of the disturbed belt in the Sun River Canyon area and the adjacent area to the east.

Society, 1955, p. 47; Mudge, 1959, p. 21). The axial trace of this anticline extends northward from the Sun River for at least 7 miles. South of the river, it can be traced only a short distance to a point where it is truncated either by a younger thrust fault or by a thrust fault that broke from its crest and obliterated the east $\operatorname{limb}$ (pl. 1).

Other folds in subbelt I are exposed only in and near Deep Creek, the Sun River, and Willow Creek (pl. 1). Widespread Quaternary deposits mantle much of the area between these drainages. Many folds near Deep and Willow Creeks appear as vertical isoclinal folds on aerial photographs. Attitudes of rocks in scattered exposures between Willow Creek and the Sun River indicate some isoclinal folds in that area.

Small thrust and normal faults in the western part of subbelt I trend nearly north, parallel to the folds. The thrust faults dip as much as $80^{\circ} \mathrm{W}$.; most have less than 200 feet of stratigraphic throw. One of the most extensive longitudinal normal faults, in the western part of the subbelt, dropped strata of the Ferdig Shale Member alongside those of the Cone Calcareous Member of the Marias River Shale, which resulted in a displacement of about 150 feet (pl. 1). In most places, this fault dips steeply to the west, although locally it dips steeply east. South of the Sun River this fault has been truncated by a younger thrust to the west in subbelt II. Two of the six longitudinal normal faults exposed in the Pishkun Canal in the NW1/4 sec. 28, T. 22 N., R. 8 W., are shown in figure 7. These faults dip $80^{\circ}-86^{\circ} \mathrm{W}$., and three of the six faults have a displacement of more than 50 feet. 


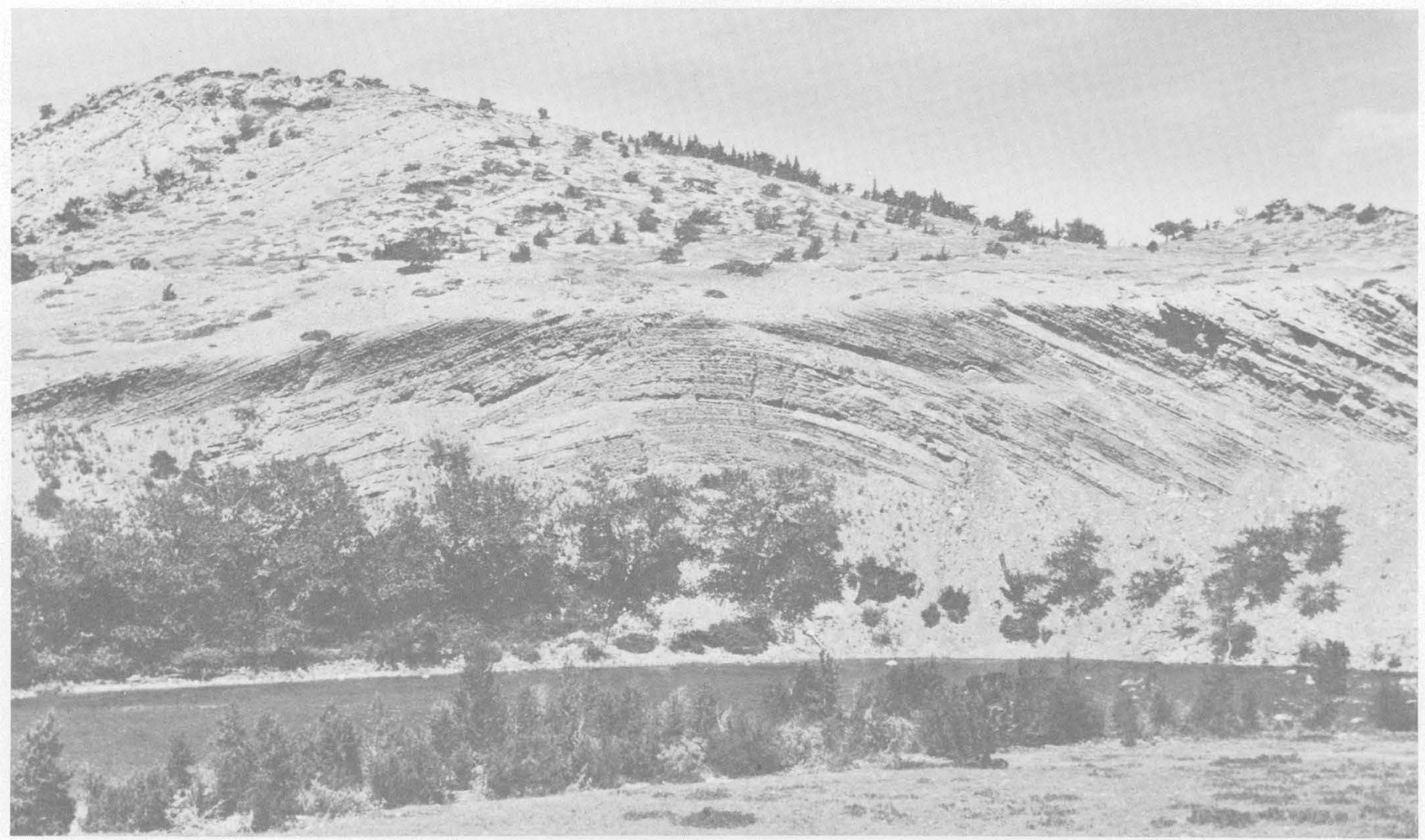

Figure 6.-Sun River anticline exposed in the north bank of the Sun River in the SE1/4 SW1/4 sec. 28 , T. 22 N., R. 8 W., Teton County. Beds of the Telegraph Creek Formation are exposed in this symmetrical anticline. The axial trace extends through the saddle to the right. The gray sandstone beds of the Virgelle Sandstone are in the east (west-dipping) limb of a syncline shown in the left part of the photograph.

\section{SUBBELT II}

Subbelt II, about $2 \frac{1}{2}$ miles wide, spans the area just east of the mountain front (fig. 5). It contains abundant closely spaced thrust faults, mostly in Lower Cretaceous rocks but locally they are in the lower units of the Upper Cretaceous. Subbelt II is equivalent to zone 2 in the Two Medicine-Badger Creek area discussed by Weimer (1955, p. 146), to the western structural area described by Stebinger (1918, p. 168), and to the central area described by me $(1959$, p. 21$)$ in a previous report. North of the Sun River, the structures in the subbelt trend nearly due north; south of the river they trend N. $15^{\circ}-25^{\circ} \mathrm{W}$.

Most thrust faults dip $45^{\circ}-60^{\circ}$ (not as steeply as those in subbelt I). Very little breccia is associated with the faults in these incompetent mudstones and sandstones. In some strata, a narrow shear zone marks the fault.

The east side of Sawtooth Ridge is mantled by thick widespread Quaternary deposits (Mudge, 1965b), which explains the absence of closely spaced structures on plate 1 for this area. Structures similar to those exposed to the north and south are assumed to underlie this covered area.

A variety of large and small folds is in subbelt II, more commonly in the northern part of the area, where some are isoclinal (pl. 1). The folds are asymmetrical with their axial planes inclined to the west; some are overturned to the east ( $\mathrm{pl} .1 \mathrm{1})$. One of the many variations along the strike of a fold is that of the axial trace of an overturned anticline which trends southward through secs. 29 and 32 , T. 23 N., R. 8 W., into an asymmetrical anticline, which farther south is broken by a thrust fault.

Two moderately large asymmetrical anticlines are exposed along Sun River. The east limb of each is broken by a moderately large thrust belonging to the imbricate zone to the east. Both anticlines, north and south of the river, are truncated obliquely by younger thrust faults to the west. These folds are sufficiently open to be classed as parallel folds, showing neither thickening nor thinning of beds. Also, the easternmost anticline, at station 19 (sec. 32 , T. 22 N., R. 8 W., pl. 1), contains beds of claystone and siltstone with closely spaced flow cleavage parallel to the axis of 


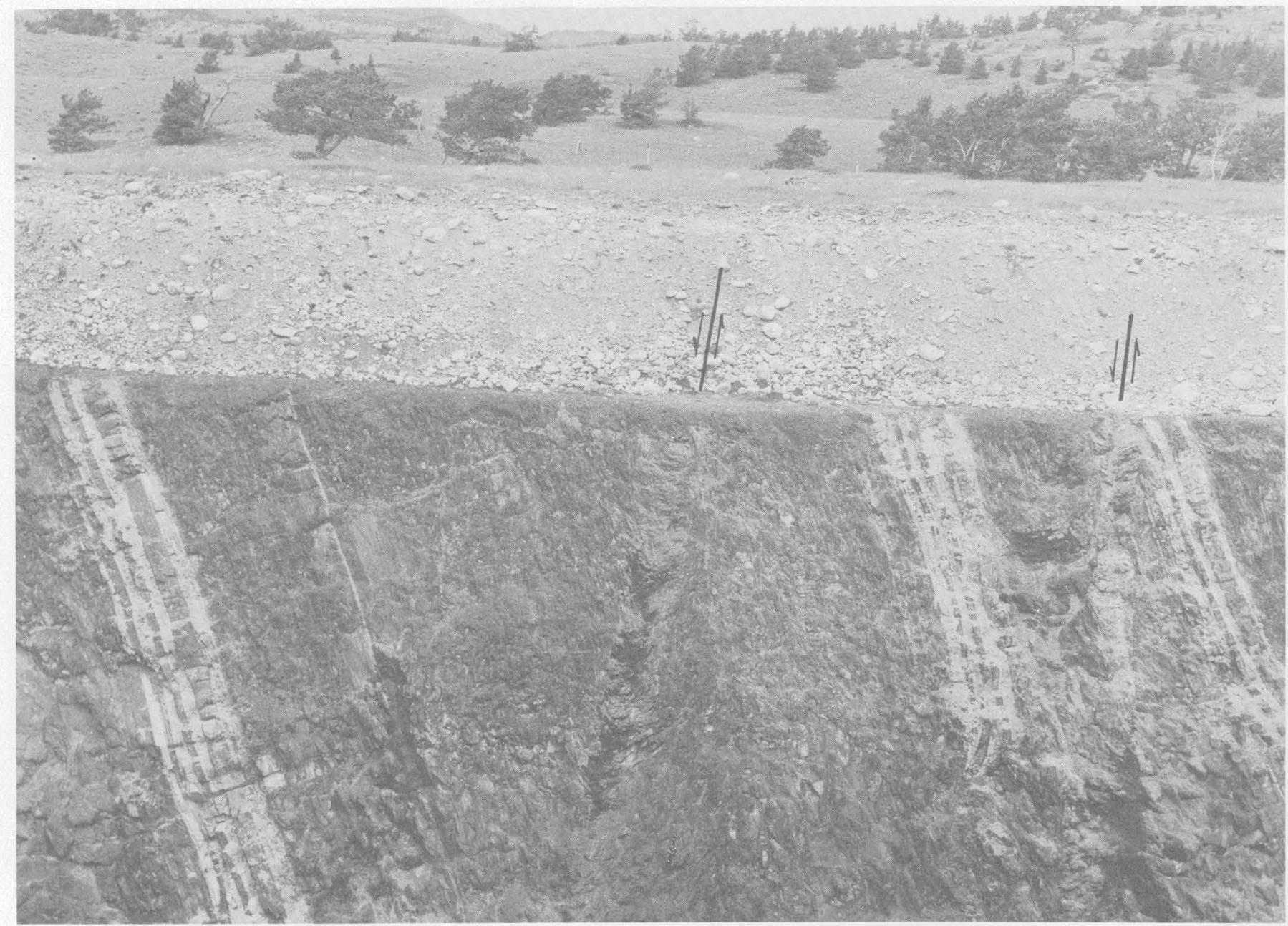

Figure 7.-High-angle longitudinal normal faults in the western part of subbelt I exposed in an irrigation canal in the center of sec. 28 , T. 22 N., R. 8 W., Teton County. These faults repeat a group of white bentonite beds and dark-gray mudstones in the Kevin Shale Member of the Marias River Shale.

the anticline. The western anticline is broken by many small thrust faults not shown on plate 1 . This anticline plunges about $15^{\circ} \mathrm{N}$. Drag folds in beds of sandstone and mudstone in the west limb of this anticline are locally broken by small thrust faults.

Many folds in subbelt II, especially the smaller ones, have thrust faults along their east limbs. These probably result from drag folds in which the incompetent strata folded during the movement of the thrust by the drag of one stratum against another. Examples of these folds are shown in figures 8 and 9 . One or more of the back-limb folds shown in figure 9 developed either before or during thrusting, as shown by the fact that the thrust is not folded. Perhaps these folds formed by flowage of the mudstone in the upper plate during thrusting.

Abundant closely spaced thrust faults characterize subbelt II (pl. 1). As many as 58 small thrust faults were seen in an east-west line across this subbelt. A well-exposed example is in the north bank of the Sun River in the $\mathrm{SE}_{1 / 4}^{1 / 2} \mathrm{NW}_{1 / 4}^{1 / 1} \mathrm{NW}_{1 / 4}^{1 / 4}$ sec. 32 , T. $22 \mathrm{~N}$., R. $8 \mathrm{~W}$. (Mudge and Dobrovolny, 1959, p. 155). There, 17 thrust faults and nine bedrock contacts are visible within a distance of 750 feet.

The major thrust faults on the east side of each of the two anticlines previously described along the Sun River have stratigraphic throws of about 1,200 feet, and both fault planes dip about $60^{\circ} \mathrm{W}$. The imbricate structure associated with these faults is referred to on plate 1 as the Neal and Stecker imbricate zones. Each zone has many closely spaced thrust faults only a few of which are shown on plate 1 . The thrust faults have stratigraphic throws of less than 500 feet and dips of $45^{\circ}-60^{\circ} \mathrm{W}$.; the dips steepen westward in each zone.

An imbricate zone near the southeast end of the ridge south of the dam at Diversion Lake consists of tightly spaced relatively low angle ( $35^{\circ}$ or less) thrust faults with stratigraphic throws of less than 300 feet. The 


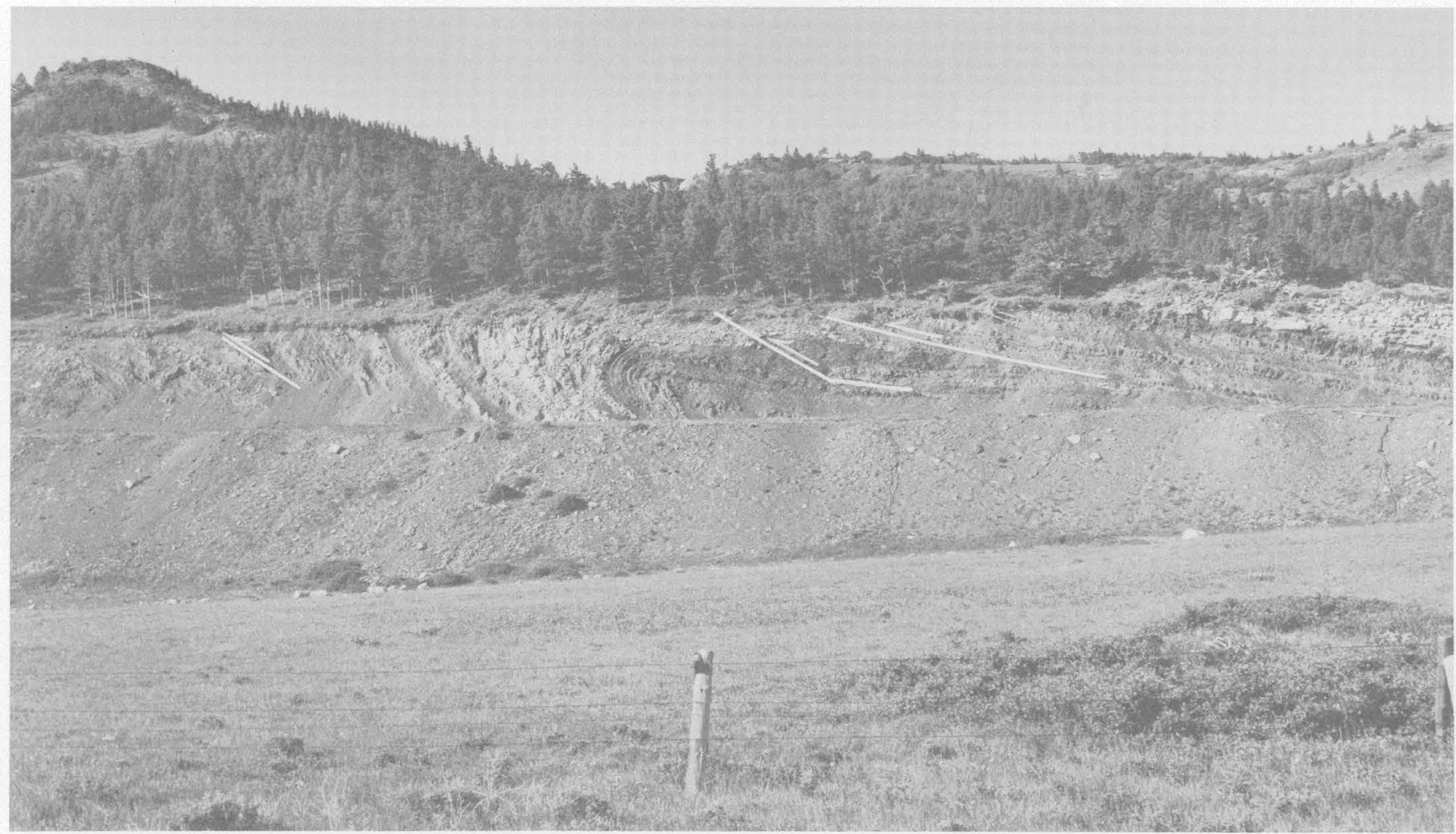

Frgure 8.- Drag fold in the Vaughn Member of the Blackleaf Formation on the south side of an irrigation ditch in the eenter of the SW1/4 sec. 32 , T. 22 N., R. 8 W., Lewis and Clark County. The low-angle thrust fault is to the left of the overturned limb of the anticline containing light-gray sandstone. Two small back-limb thrusts are on the right (west) of the anticline.

Diversion thrust truncates this zone at an angle of about $30^{\circ}$.

Other thrust faults, not included in imbricate zones, have stratigraphic throws of less than 500 feet and dips of as much as $80^{\circ} \mathrm{W}$.

Near Sun River, most strata strike parallel to the thrust faults and dip at lower angles than the thrusts. Thus, along the river, the rocks at the base of most thrust plates are older than those at the base of the same plates at higher elevations both north and south of the river. Similar relations are also common in other subbelts.

A group of easterly trending anomalous structures with closely spaced thrust faults, is exposed south of the Sun River along the north edge of secs. 16 and 17, T. 21 N., R. 8 W. During movement, some thrust faults deviated sharply into an easterly strike and truncated one or more underlying thrust blocks. These anomalous structures can be traced westward through many fault blocks almost to Allan Mountain (Mudge, 1965a, 1966a). The complexity of some of these structures is illustrated in figure 10, which shows strata of the Blackleaf Formation repeated by four tightly folded thrust faults. Flowage in the tightly compressed syncline created a small thrust fault that dips eastward, contrary to the normal structural pattern.

Northeasterly to easterly trending normal faults in the southern part of subbelt II displace the thrusts (pl. 1). The two small normal faults have displacements of less than 50 feet.

\section{SUBBELT III}

Subbelt III contains many folds, large thrust faults, and some normal faults. This subbelt contains most of the eastern and central parts of the Sawtooth Range (fig. 11) between the mountain front and the Elk fault along the east side of the valley of the North Fork of the Sun River (fig. 5). Subbelt III is equivalent to all three structural provinces described by Deiss (1934b., p.1151-1154) and probably also to zone 3 of Weimer (1955, p. 146) in the Two Medicine-Badger Creek area. Subbelt III is divisible lengthwise on the basis of subtle differences in stratigraphy. Subbelt IIIa is the eastern province of Deiss (1934b, p. 1149) and the western structural area of Mudge $(1959$, p. 22). Subbelt IIIb contains the central and western provinces of Deiss (1943b, p. 1149). Cambrian rocks are present in two of the fault blocks in the eastern part of Subbelt IIIb, 
WEST

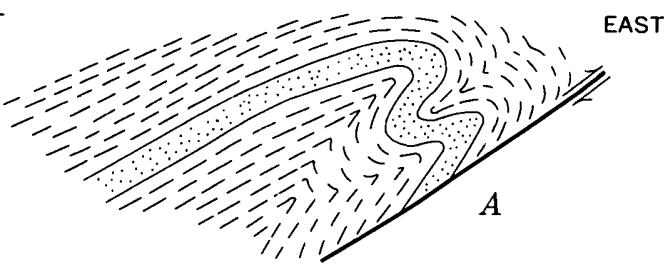

$\stackrel{1}{i} \quad 100 \mathrm{FEET}$

WEST

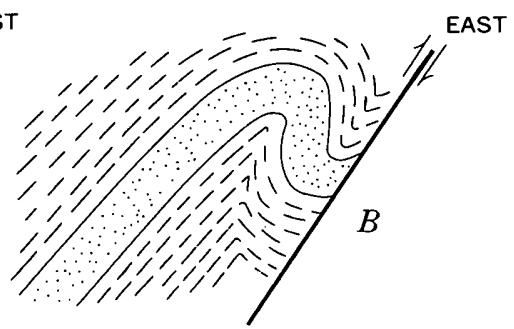
GOFEET

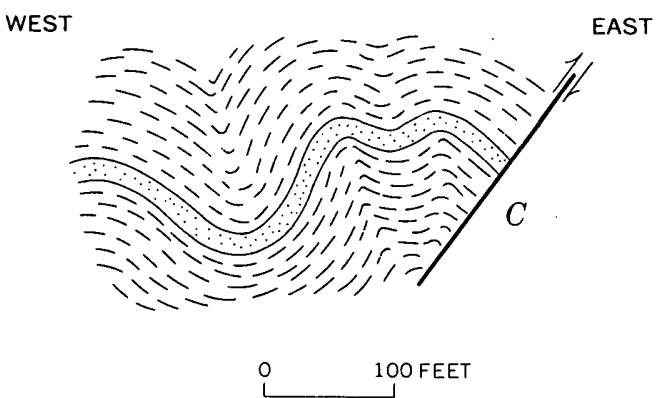

Fraure 9.-Small folds in subbelt II in the Sun River Canyon area. $A$, Streambank at station 34 (pl, 1), about $1 \frac{1}{2}$ miles south of Diversion Dam. $B$, Streambank of Sun River at station 12 (pl. 1), NW1/4 NE1/4 sec. 32 , T. 22 R. 8 W. C. Streambank at station 27 (pl. 1 ), in $\mathrm{SE}^{1 / 4} \mathrm{NW}^{1 / 4}$ sec. 6 , T. $21 \mathrm{~N}$., R. $8 \mathrm{~W}$. Dotted pattern, sandstone; dashed pattern, mudstone; heavy lines with arrows, thrust faults showing direction of movement.

which indicates that these thrusts have stratigraphic throws of as much as 6,000 feet. These beds are absent from Subbelt IIIa. The subdivisions are discussed in more detail in connection with the mechanics of thrust faulting.

Subbelt III contains many major westerly dipping moderately high angle thrust faults whose stratigraphic throws range from 3,000 to 6,000 feet. Most fault blocks have Mississippian carbonate at the base, overlain by Jurassic and Lower Cretaceous mudstones and sandstone. Devonian rocks (Jefferson Formation) constitute the sole of the Home thrust block in the eastern part of subbelt IIIa in the Castle Reef-Sawtooth Ridge

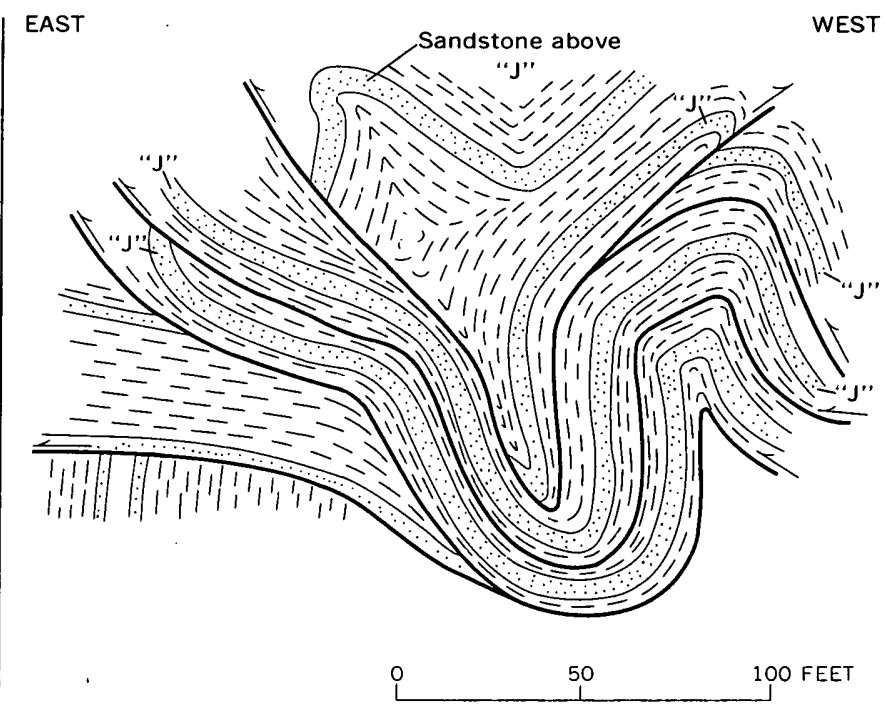

FiguRE 10.-Folded thrust plates in streambank at station 47 (SE1/4NE1/4 sec. 18, T. 21 N., R. 8 W., pl. 1), east of north end of Sawtooth Ridge. Dotted pattern, sandstone; dashed pattern, mudstone; heavy lines with arrows, thrust faults showing direction of movement. J, a sandstone bed repeated by thrusting.

area. Small back-limb thrust faults are characteristic in the Rierdon Formation in almost all of the major thrust blocks.

The trends of the structures in subbelt III north of the Sun River differ from those to the south. Near the river a few structures trend slightly east of north. Farther north the trend is due north in the eastern part of the subbelt but $\mathrm{N}$. $10^{\circ}-20^{\circ} \mathrm{W}$. in the western part. South of the Sun River most structures trend from $\mathrm{N} .10^{\circ}$ to $20^{\circ} \mathrm{W}$., increasing southward to N. $25^{\circ}-30^{\circ} \mathrm{W}$. Thus the Sun River is incised along an east-west flexure where there is a change in the trend of the structures.

Asymmetric anticlines, some of which are overturned, are present where large fault blocks plunge beneath the surface, especially in subbelt IIIa. Examples of these anticlines are in Hannan Gulch near the Sun River; at the head of French Gulch; at the north end of Sawtooth Ridge; at the north and south ends of Diversion Ridge (fig. 12); and at Battle Creek. At each, Mississippian, Jurassic, and Cretaceous rocks form a plunging anticline with a thrust fault beneath the east limb. The absence of evidence of flowage of the rocks in the anticline indicates that a thrust fault broke from a fracture in the east limb of the anticline, whose crests are preserved only where they plunge beneath the ground. Elsewhere along the ridge fronts, the remnants of the folds have been eroded.

In places some incompetent strata in the lower plate were folded during the thrust movement of the upper plate (fig. 13). Small recumbent anticlines in the Flood 


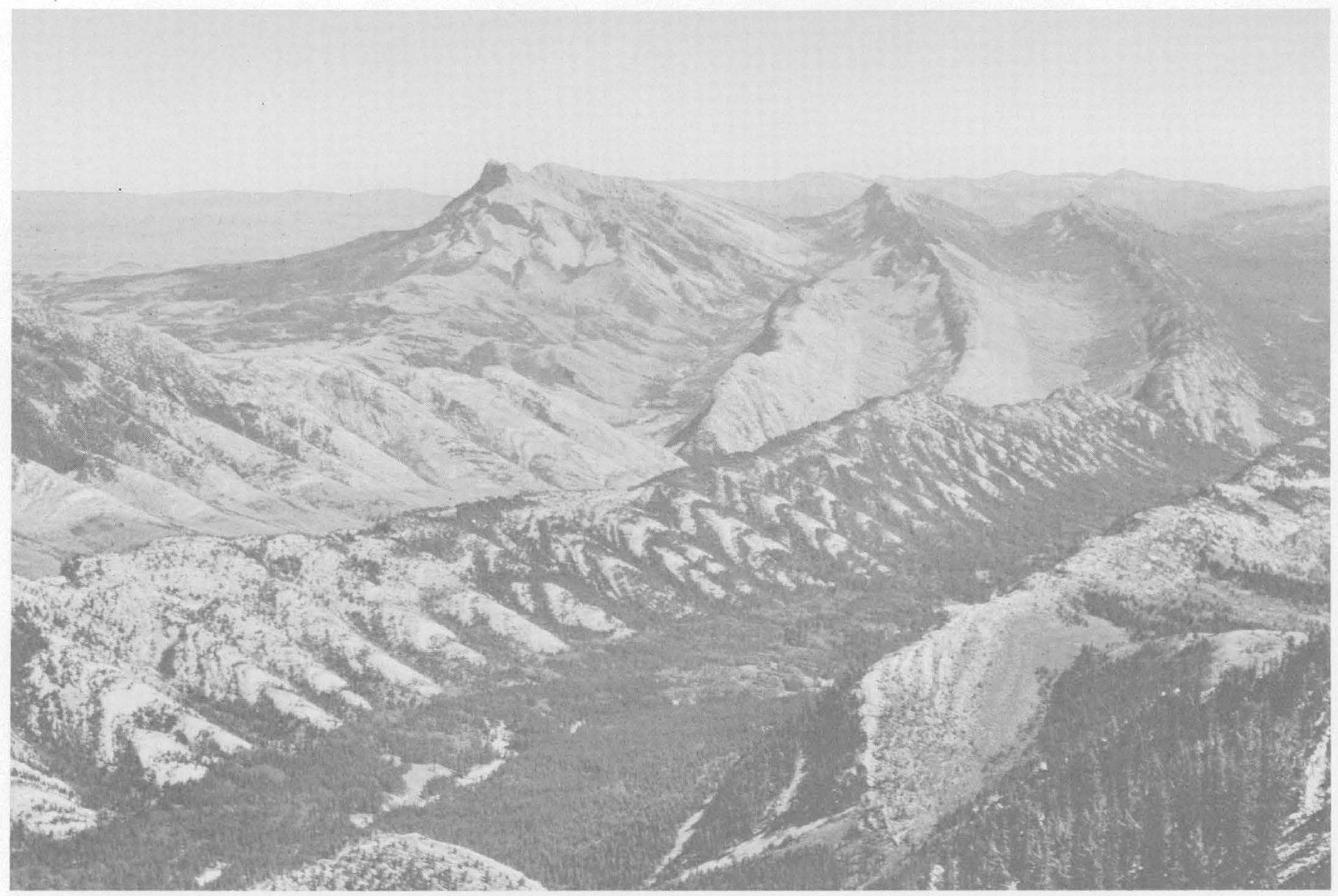

FIgURE 11.-View southeast across the eastern Sawtooth Range. Sawtooth Ridge is the high mountain in the upper left. The parallel ridges are Mississippian carbonates in thrust contact on Lower Cretaceous rocks along the west (right) side of each valley. Jurassic rocks are along the east (left) side of each valley. The Sun River Canyon is at the low point of each ridge. Thus the Sun River and its tributaries form a fault-trellis drainage pattern.

Shale Member of the Blackleaf Formation are along the west side of Wagner Basin, along the west side of a northerly trending tributary of Cut Rock Creek and at the head of Home Gulch. Each anticline exhibits a thrust fault along its axial plane.

Other minor folds, mostly asymmetrical, are in Lower Cretaceous rocks east of the large thrust faults in upper Beaver Creek and south of Diversion Lake.

Flowage of the incompetent mudstones between somewhat more competent beds of carbonate rock or sandstone is evident in many folds in subbelt III (figs. $14,15)$. The mudstone is thicker on the fold axes and thinner along the limbs of these structures. Some anticlines show small isoclinal folds in incompetent mudstones near their crests.

A breccia which is very thin but which varies in thickness is common along thrust faults. Most fault surfaces are sharp and clean and contain less than 1 foot of breccia in either plate; locally breccia is absent (fig. 16). The thickest breccia observed was along the
Diversion thrust (pl. 1) where the lower 36 feet of carbonate beds in the upper plate and at least 30 feet of mudstone and sandstone beds in the lower plate are brecciated. Some breccia masses contain fragments from both plates. Generally the uppermost beds of the lower plate are highly sheared whether carbonate rock was thrust on mudstone or carbonate.

Normal faults are in subbelt III (pl. 1; Mudge, 1972, pl. 1). The movement of some of the faults is difficult to ascertain; some of them may be transverse (tear) faults. The Elk fault is a longitudinal normal fault which is discussed later in this report. Easterly trending normal faults displace thrust faults at Sawtooth Ridge (pl. 1). The two faults east of the ridge may be transverse (tear) faults. The faults at the ends of Sawtooth Ridge are readily classified as normal or strike-slip faults. The fault at the south end of the ridge displaces the Sawtooth thrust and many imbricate thrust faults to the east; as displacement dies out toward the southwest, the fault hinges at the west and is a normal fault. It 


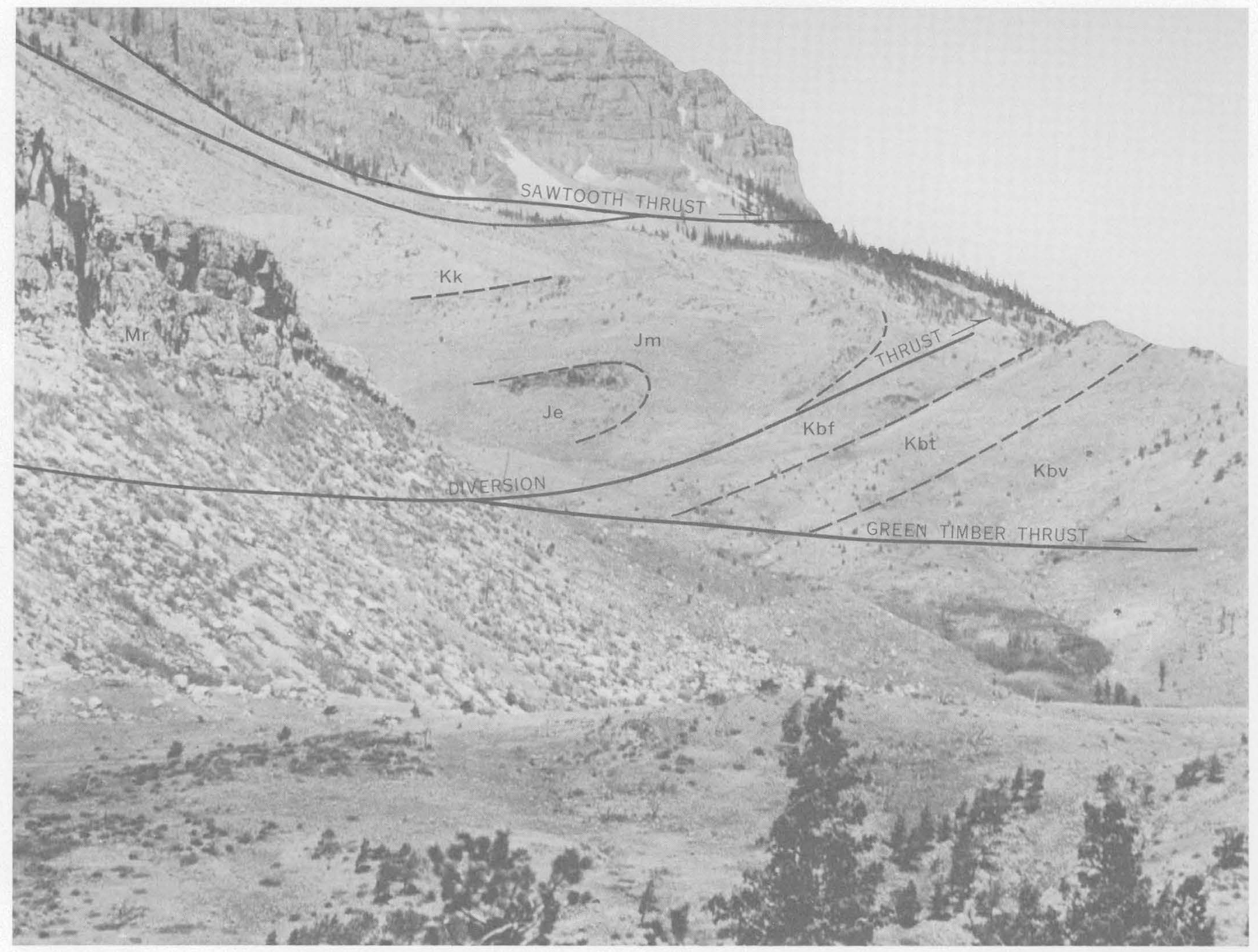

Figure 12.-Telephotographic view looking north at the north end of Diversion Ridge, showing overturned Jurassic and Cretaceous strata. Strata between the Diversion and Green Timber thrust faults are also overturned. Mr, Mississippian rocks undifferentiated; Je, Ellis Group; Jm, Morrison Formation; Kk, Kootenai Formation; Kbf, Flood Shale Member, Kbt, Taft Hill Member, and Kbv, Vaughn Member, all of Blackleaf Formation.

strikes N. $45^{\circ}$ E., dips $45^{\circ}$ N., and has a displacement of about 50 feet. At the north end of the ridge, a fault displaces the Sawtooth, Home, and Barr thrusts and some imbricate thrust faults to the east. This normal fault, downthrown to the south, strikes N. $80^{\circ}$ E., dips about $30^{\circ} \mathrm{S}$., and has a displacement of about 100 feet. Excellent exposures of both blocks of this fault reveal no strike-slip component. The area between the faults is a graben. A longitudinal section of Sawtooth Ridge would show this graben bowing convexly upward between the two faults, with the structural high point near the topographic high point of the ridge.

\section{DIVERSION AND DEEP GREEK THRUST BLOGKS}

The Diversion and Deep Creek blocks are the easternmost major blocks in subbelt III in the Sun River
Canyon area (pl. 1). Both plunge southward; the Deep Creek block plunges somewhat southwestward. Both are truncated on the west by a younger thrust fault.

The Deep Creek thrust block is well exposed along Deep Creek, where Mississippian rocks, in a broad asymmetrical anticline, lie in thrust contact above Lower Cretaceous rocks (Mudge, 1972, pl. 1). A narrow strip of overturned strata of the Vaughn Member of the Blackleaf Formation underlies a thrust to the east and represents a remnant of the overturned east limb of the anticline. The fault to the east of this overturned sequence is very likely the initial thrust. Between the initial thrust and the anticline are small younger thrusts in overturned Jurassic and Cretaceous rocks. North of Deep Creek, related klippes of overturned Jurassic rocks rest in thrust contact on the Vaughn 


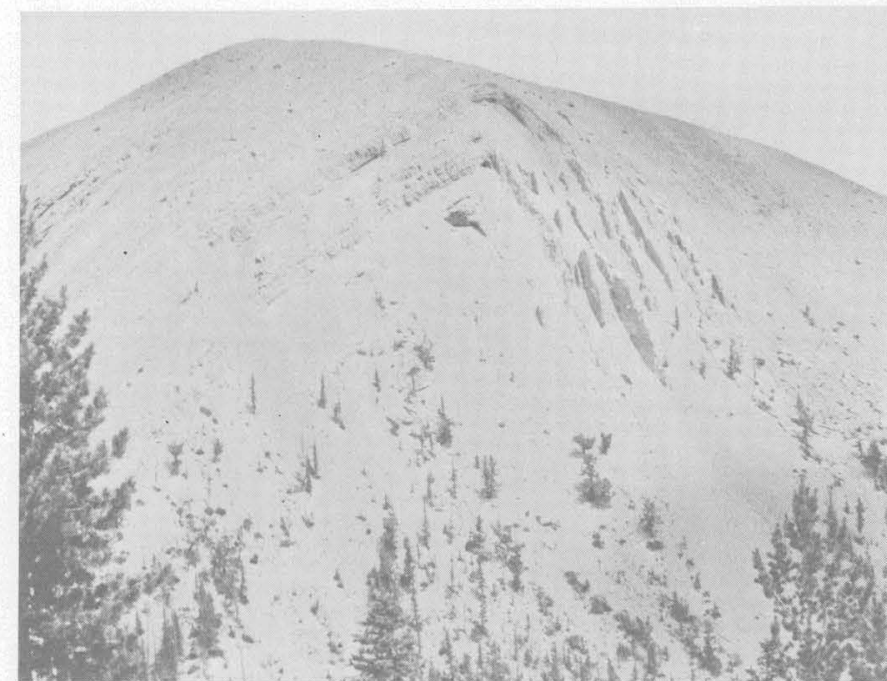

FigURE 13.-View looking north at a northward-plunging asymmetrical chevron fold in Devonian rocks in the upper reaches of Erosion Creek. The resistant ledges are in the upper member of the Maywood Formation and are overlain by the Jefferson Formation (ridge line). This fold is part of a folded thrust plate; a syncline and a thrust fault are exposed east of the area of the photograph. The fault is beneath the talus shown in the lower part of the photograph. A younger, overlying thrust fault is west of the area of the photograph.

Member of the Blackleaf Formation (Mudge, 1972, pl. 1). Near Sun River, this initial thrust truncated all the Stecker imbricate zone. All the thrust faults and the overturned Vaughn strata are cut off on the south by the Diversion thrust, which, to the south of the Sun River (pl. 1; Mudge, 1972, pl. 1), also cuts part of the westernmost imbricate zone of subbelt II.

The basal part of the Diversion thrust block is exposed in and near the Sun River (fig. 12), north along the east side of No Business Creek, and north of Deep Creek (pl. 1; Mudge, 1972, pl. 1). Jurassic, Cretaceous, and Mississippian rocks are folded at each end of the ridge, both north and south of the Sun River (fig. 12). South of the Sun River, the thrust is dissipated in an imbricate thrust zone in Lower Cretaceous rocks. At least two thrust faults in this zone were subsequently overridden by a small low-angle thrust (pl. 1).

\section{SAWTOOTH THRUST BLOCK}

The Sawtooth thrust block forms Sawtooth Ridge and Castle Reef, the two most prominent landmarks along the east front of the northern Rocky Mountains near Sun River (pl. 1). The block consists of Devonian strata below, overridden by Mississippian, Jurassic, and Cretaceous rocks in a younger thrust block (Mudge, 1972 , pl. 1). The underlying Home thrust block in Wagner Basin, Home Gulch, and along the east face of Sawtooth Ridge exposes only Devonian strata. Beneath the Home thrust, and related to it, are isolated exposures of deformed and sheared Mississippian rocks. (See Mudge, 1965a.)

Excellent exposures at Castle Reef permit reconstruction of the origin of the structure in that mountain (figs. 17, 18). During stage I (fig. 18), the Home thrust emplaced Devonian (Jefferson Formation) and younger rocks onto Lower Cretaceous rocks. A remnant of the east limb of the fold, where this fault may have originated, dips steeply eastward. In stage II, continued stress on the Home thrust created a subsequent thrust, which overrode part of the east limb of the fold and thrust. In stage III, the bedding-plane Sawtooth thrust formed at a higher level, cut across underlying strata, and merged with the second (subsequent) thrust. In the final stage (IV), a minor younger thrust repeated part of the Allan Mountain Limestone at a higher elevation.

The faults of Castle Reef are also present in northern Sawtooth Ridge, except for the minor younger thrust, but at Sawtooth Ridge an older thrust block of Mississippian rocks lies below the Home thrust (Mudge, 1972, pl. 1). As shown in the frontispiece, the sequence in Sawtooth Ridge differs from north to south because some strata are cut out by thrust faulting. At the south end of the jagged peaks, the underlying Barr thrust block is truncated abruptly by the Home thrust. There the Barr thrust steepened upward before the Home thrust cut steeply downward at nearly right angles across the underlying block. Farther south, the Sawtooth thrust truncates the underlying Home thrust and the intervening strata (Mudge, 1965a).

A double fenster is exposed in a large glacial cirque on the west side of Sawtooth Ridge (fig. 19; Mudge, 1971, pl. 1), where the Sawtooth and Home thrust blocks and underlying rocks are well exposed (fig. 19; pl. 1; Mudge, 1965a).

A structural terrace persists along the west side of Castle-Reef and Sawtooth Ridge. It is most evident where the Mississippian strata locally flatten out on the east side of upper Home Gulch and in lower Hannan Gulch.

\section{ALLAN THRUST BLOCK}

The complex Allan thrust block extends southward through the Arsenic Peak and Patricks Basin quadrangles and forms the highest mountain ridge in the central Sawtooth Range (pl. 1). The ridge, whose high points are Arsenic Peak and Allan Mountain, exposes Cambrian, Devonian, Mississippian, Jurassic, and Lower Cretaceous rocks. The Allan thrust block resembles a structure in central Turner Valley, Alberta, described by Gallup (1951, p. 806), Link (1949, 1953), and Hume (1957, p. 398). Gallup showed that an irregularity in the sole thrust created a fold and sub- 


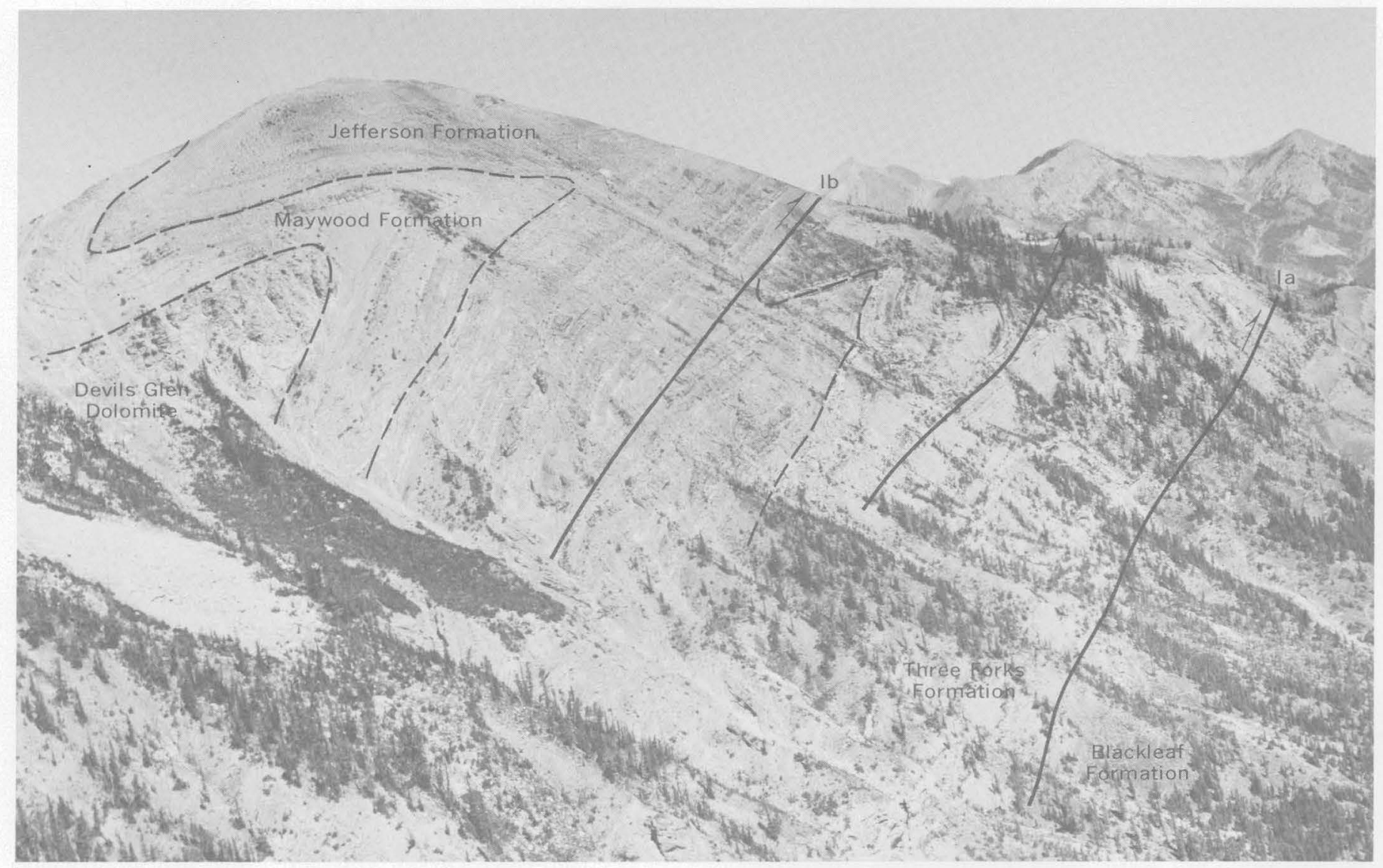

Figure 14.- View to the north of overturned folds in the Cambrian (Devils Glen Dolomite) and Devonian strata at the head of the South Fork of Deep Creek. Along the right side, Devonian rocks (Three Forks Formation) are in contact across a large thrust with Lower Cretaceous rocks (Taft Hill Member of the Blackleaf Formation). Across two smaller thrust faults,

sequent thrust faults. Back-limb thrusts cut the Allan thrust blocks as they do the Turner Valley structure.

The complexity of the structure in the Allan fault block is illustrated on plate 4 by 12 cross sections, spaced no more than $2 \frac{1}{2}$ miles apart, for a distance of 20 miles along this ridge. The strike is N. $10^{\circ}-20^{\circ} \mathrm{W}$. in the northern part, due north to N. $5^{\circ} \mathrm{E}$. just north of the Sun River, N. $10^{\circ}$ W. south of the river, and N. $20^{\circ}$ $W$. in the southern part. The Allan thrust was the basal thrust fault that probably started along a fracture in the east limb of an overturned anticline. Most of the Allan thrust fault is a single break, but toward the north it becomes an imbricate fault zone. The westerly dip of the Allan thrust ranges from $20^{\circ}$ to $60^{\circ}$. The stratigraphic throw is about 6,000 feet. Remnants of the overturned limb are preserved in many places as the sole of this thrust plate (pl. 4 ; fig. 20). The overturned limb dips from $45^{\circ} \mathrm{W}$. to almost vertical. The dip of the west limb of the anticline ranges from $40^{\circ}$ to $80^{\circ} \mathrm{W}$. and in most places is $55^{\circ}-70^{\circ} \mathrm{W}$. This fold may be a large drag some of the Devonian rocks are repeated. Note that the Devonian Maywood Formation forms a flexural-flow relation, whereas the underlying Cambrian Devils Glen Dolomite is in a flexural-slip relation. See section $A-A^{\prime}$ of ridge containing Fairview Mountain, Allan Mountain, and Arsenic Peak (pl. 4).

fold like one in Alberta discussed by Irish (1965, p. 103). However, it is doubtful that as large a fold as this in Allan Mountain could have been formed by frictional drag.

Many younger thrusts of small displacement developed at various positions within the anticline (pl. 4; fig. 20). On plate 4 , subletters to the numerals are used on some faults to indicate possible correlation of a fault in the northern area with one to the south. The numerals indicate the order in which these faults originated.

Fault IV (pl. 4) parallels the underlying faults through section $K-K^{\prime}$, but to the south it strikes eastward and truncates all of the underlying fault plates in the Allan thrust block. At section $L-L^{\prime}$, fault IV is the main thrust, and there the fault block, like many others in subbelt III, has Devonian rocks at the base.

The structural complexity of the Allan thrust block increases markedly northward from the head of Big George Gulch. In the northern three sections $\left(A-A^{\prime}\right.$ to $C-C^{\prime}$ ), the initial thrust fault changed from a moderately 


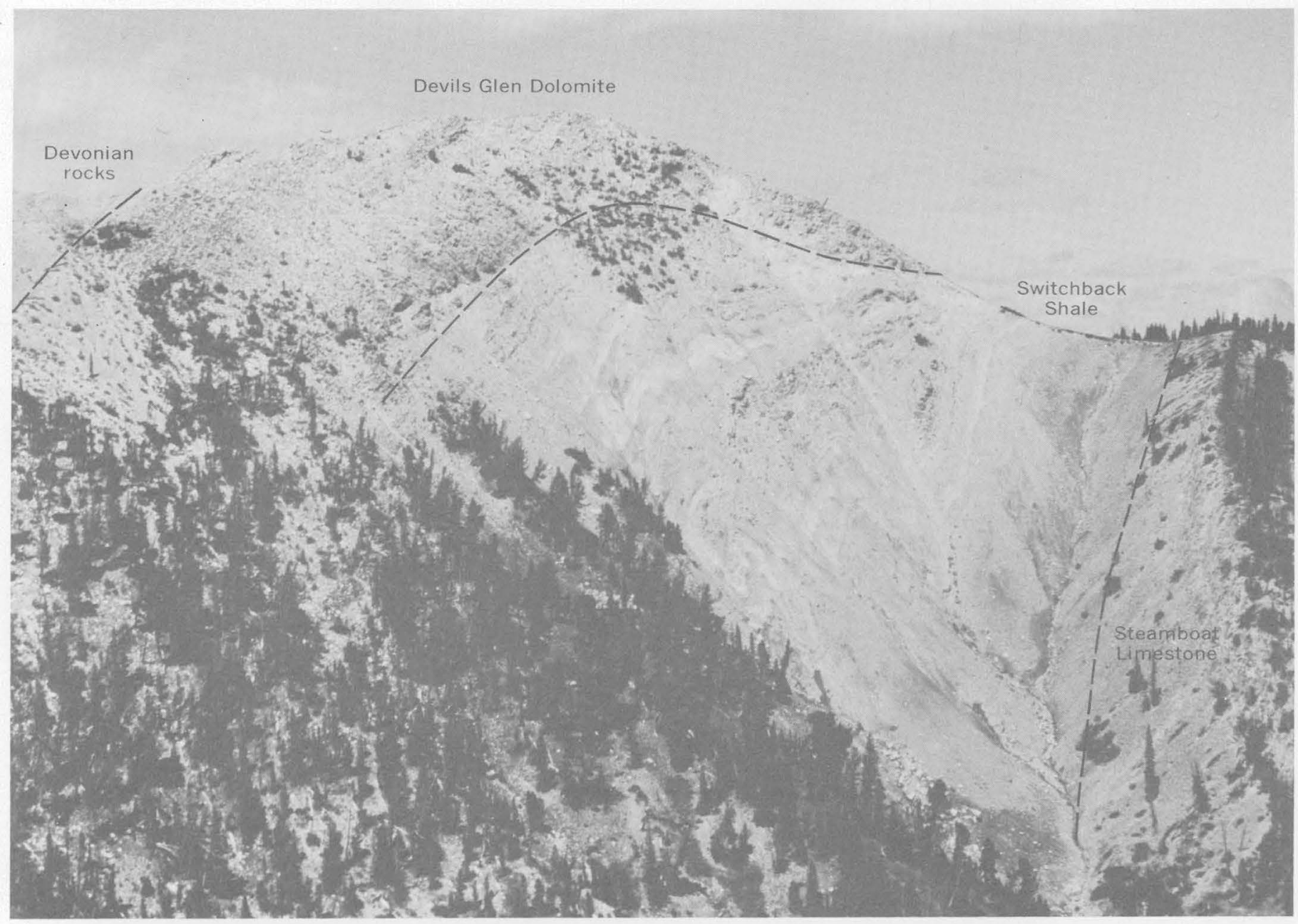

FIgURE 15.-Flow folds in the incompetent Switchback Shale between the competent Steamboat Limestone (below) and the Devils Glen Dolomite (above) exposed about half a mile northeast of Arsenic Peak. In this general area, the uncontorted Switchback Shale ranges in thickness from 200 to 250 feet, its approximate width at the saddle. Within the anti- cline, the flow folds have nearly tripled the thickness of the formation. Flow folding is absent in the underlying Steamboat Limestone. The Steamboat lies a short distance above a thrust fault, which is exposed east of the area of the photograph. high-angle to a low-angle dip, and many later thrusts formed, especially in the overturned limb (pl. 4).

The thrust plates are also folded in the northern part of the area (sections $A-A^{\prime}$ and $B-B^{\prime}$ ). The outcrop pattern of fault IV shows the warping best. In upper Cabin Creek, fault IV is folded in the Biggs Creek syncline and Beartop anticline (pl. 1), which are also well exposed on Biggs Creek, about 1 mile north of the area (fig. 21). Inasmuch as fault IV is younger than the other faults in this block, the underlying fault plates are almost surely also involved. As interpreted from the sections, the folding of the earlier thrusts varies from plate to plate. In section $A-A^{\prime}$, the piling of thrust plates to the east probably created a barrier to additional movement of the thrusts, and renewed stress from the west created the folds in the western part of the plate. Folding also brought about a change from a steep dip to a low-angle dip in the thrust plate.

Figure 14 shows the complexly folded and faulted thrust plates in the eastern part of section $A-A^{\prime}$; Cambrian and Devonian rocks in an overturned fold overlie a series of closely spaced isoclinal overfolds with minor thrust faults. These incompetent strata are between two thrust faults. The older thrust, fault Ia, is shown to the right; fault IIb is out of view on the west (left).

\section{SHEEP REEF STRUCTURES}

Sheep Reef is capped by a trachyandesite sill which invaded Lower Cretaceous rocks. The sill forms Sun Butte and Black Reef to the south and extends northward along the west side of subbelt III. This sill intruded 


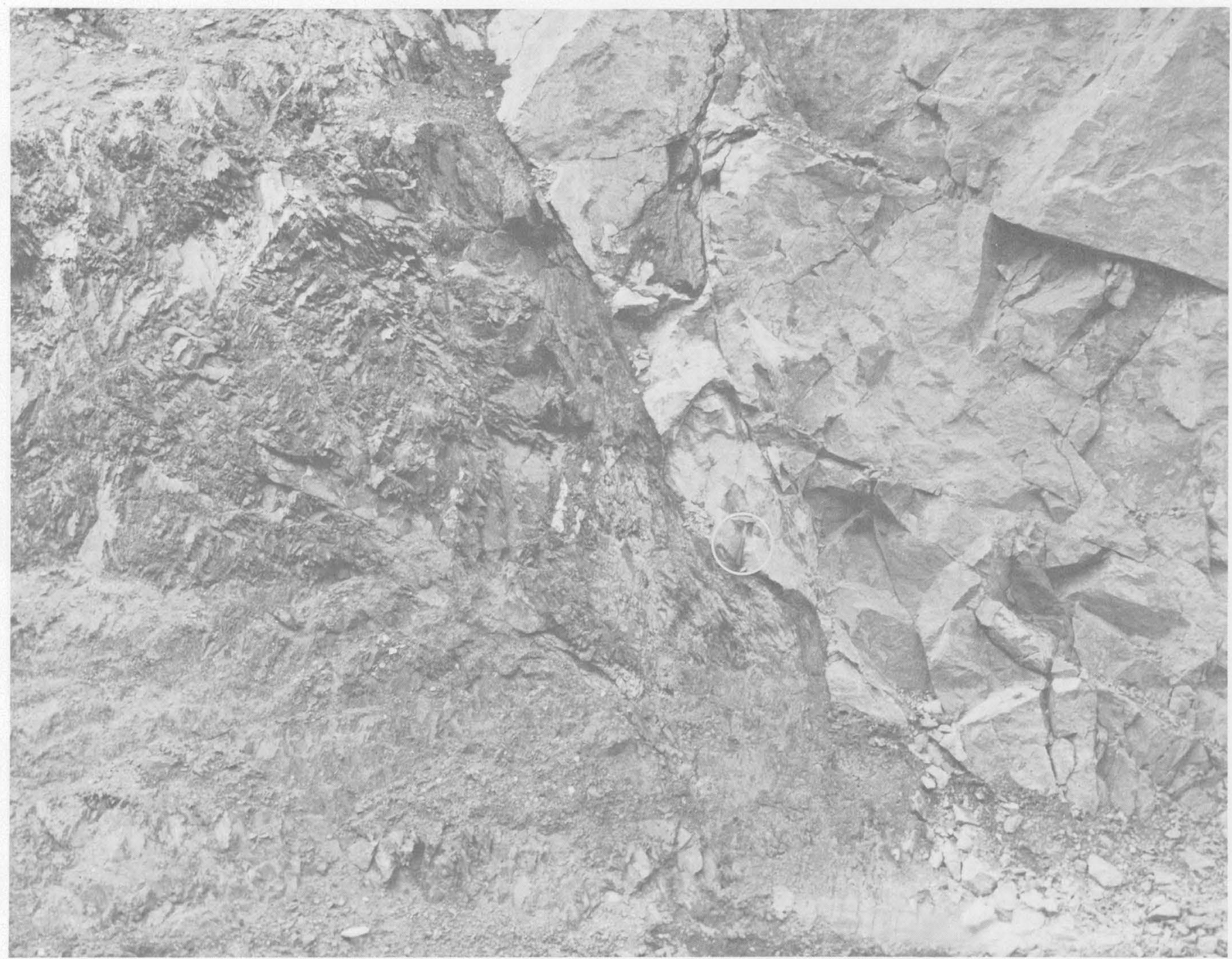

Figure 16. A view of the French thrust in a roadeut on the west side of French Gulch just south of the Sun River. This thrust places the lower beds of the Castle Reef Dolomite (light gray) onto the Flood Shale Member of the Blackleaf Formation (dark gray). The fault dips $60^{\circ} \mathrm{W}$., and the overlying strata dip about $50^{\circ} \mathrm{W}$. The black shales beneath the fault are badly crumbled, whereas the carbonate beds above it are undisturbed. Note hammer (in circle) for scale.

Lower Cretaceous rocks early in the folding of the Circle Creek anticline and the Bridge Creek syncline. A similar fold in the sill and adjacent strata is exposed at Black Reef, south of the Sun River (Mudge, 1972, pl. 1). There the sill, bordering strata, and overlying thrust blocks are in a tightly folded northwest-plunging anticline and syncline.

\section{ELK FAULT}

The Elk fault, which forms the west boundary of subbelt III, is a longitudinal normal fault that parallels the other structures in the subbelt (pl. 1); it trends due north, except toward the north, where it trends N. $20^{\circ} \mathrm{W}$. The downthrow is to the west, and the displacement is from 200 to at least 600 feet. North of the North Fork of the Sun River, the westward dip of the fault ranges from about $45^{\circ}$ to nearly vertical; to the south the dip is about $80^{\circ} \mathrm{W}$. in the South Fork (sta. 133, pl. 1). Farther south, this fault is truncated by the thrust fault along the east boundary of subbelt V. Small antithetic faults are locally present in the downthrown block of the Elk fault.

\section{SUBBELT IV}

Subbelt IV is wedge shaped, $3 \frac{1}{2}$ miles wide at the base, and spans much of the valley of the North Fork of the Sun River (fig. 5). Subbelts IV and V very likely correlate with zone 4 in the Two Medicine-Badger Creek area (Weimer, 1955, p. 146). These two subbelts form a narrow band of Cretaceous rocks between the Paleozoic 
rocks of the Sawtooth Range to the east and the Precambrian rocks of the Lewis and Clark Range to the west.

Subbelt IV is underlain by Upper Cretaceous rocks that have been folded and cut by small thrust faults (Mudge, 1972, pl. 1). It is like subbelt I both lithologically and structurally. A few small normal faults are in the southern part. The strike is $\mathrm{N} .15^{\circ}-20^{\circ} \mathrm{W}$. in the northern part and N. $5^{\circ} \mathrm{E}$. in the southern part. This subbelt is bounded on the east by the Elk fault and on the west by a thrust block of Lower Cretaceous rocks making the subbelt a wedge-shaped area. Much of it is a broad open synclinorium with small anticlines and synclines in the east limb (Mudge, 1972, pl. 1). The west limb is overturned in places and is steeply inclined elsewhere.

Moderately small thrust faults parallel the trend of folds along the west side of subbelt IV (pl. 4). These thrusts dip $40^{\circ}-60^{\circ} \mathrm{W}$, at lower angles than the thrust faults in the western part of subbelt I. The stratigraphic throw of these faults is about 500-1,500 feet, the dipslip movement is $900-2,600$ feet, and the strike slip is 750-1,750 feet. Small open folds lie in each of the thrust blocks, as in subbelt I.

A small folded thrust plate, which demonstrates postthrust folding, is exposed along Freezeout Creek, about 1 mile southwest of the North Fork of the Sun River (fig. 22). There, Upper Cretaceous rocks are repeated by a small thrust fault. The fault, as well as the overlying and underlying strata, is folded into small monoclines.

\section{SUBBELT $V$}

Subbelt V-which is $1 / 2-3$ miles wide and which, like subbelt II (fig. 5), consists entirely of thrust-faulted and folded Lower Cretaceous rocks - is probably equivalent to part of zone 4 of Weimer (1955, p. 146) farther north. This subbelt strikes $\mathrm{N} .15^{\circ} \mathrm{W}$. in the north, N. $35^{\circ} \mathrm{W}$. in the south, and N. $30^{\circ}$ E. locally near Sheep Mountain. The only competent rock exposed in the subbelt is the trachyandesite sill at or near the base of the Flood Shale Member of the Blackleaf Formation.

Folds are numerous in subbelt $\mathrm{V}$, and the larger ones are associated with thrust faults. The broad slightly asymmetrical Moose anticline along the west margin of the northern part of the subbelt (pl. 1) is overturned to the east in the southern part, especially east of Sheep Mountain. A small recumbent fold at station 205 on the south side of Moose Creek valley (fig. 23) exposes the Flood Shale Member of the Blackleaf Formation, a sill, and the upper beds of the Kootenai Formation, all overturned to the east. The fold is broken by a small horizontal thrust and two small reverse thrusts. Other small slightly asymmetrical synclines and anticlines are in some of the fault blocks in the eastern part of the subbelt (pl. 1).
Thrust faults abound in subbelt V, especially in the southern part. Most dip $30^{\circ}-50^{\circ} \mathrm{W}$.; locally some are nearly horizontal or almost vertical. The largest thrust bounding the subbelt on the east has a stratigraphic throw of about 1,500 feet. To the south, this fault truncates obliquely all structures and strata of subbelt IV and some of subbelt III. Other thrust faults in subbelt $\mathrm{V}$ have stratigraphic throws of as much as 500 feet, and usually the same units are repeated across them.

\section{PRETTY PRAIRIE FAULT COMPLEX}

The Pretty Prairie fault complex, a pile of folded thrust plates, is well exposed near South Fork and southward along the ridge between Big Head Gulch and Lange Creek (pl. 1). The thrust plates contain parts of the Kootenai and Blackleaf Formations and a trachyandesite sill in the lower sandstone unit of the Flood Shale Member of the Blackleaf (pl. 4). The lower part of the fault complex, in particular, contains closely spaced thrust plates; some are overturned and in part truncated by later thrusts.

All structures in the north half of the Pretty Prairie fault complex plunge to the northwest. Near the south Fork of the Sun River, the amount of plunge is about 1,500 feet per mile, diminishing to about 300 feet per mile between Goat and Bear Creeks.

A folded thrust plate is well exposed at station 146 in upper Bench Mark Creek (fig. 24) and near the Southwest end of section $D-D^{\prime}$. There, some and perhaps all the folding was concurrent with faulting. Toward the east, the syncline in the lower plate could have formed prior to thrusting, as it is not present in the upper plate; however, it probably formed during thrusting by the squeezing of incompetent beds in the lower plate. The anticline in the west affects both plates. The isoclinal folds in the crestal area of the anticline in the upper plate are drag folds formed by flowage in the mudstones above and below the limestone bed.

\section{SUBBELT VI}

Subbelt VI, about $1 / 2-1$ mile wide, consists mostly of one large thrust block of Mississippian rocks which is overlain by Jurassic and Lower Cretaceous rocks, as are many fault blocks in subbelt III (fig. 5). Along Glenn Creek, the Jurassic and Mississippian rocks are truncated at a $20^{\circ}$ angle by a thrust fault overlain by a plate of Lower Cretaceous rocks (Mudge, 1966c), and the lower plate is cut out entirely at the surface. The thrust plate of Cretaceous rocks persists northward as a linear strip about 1 mile wide. In the Marias Pass area, subbelt VI, if present, is included in zone 4 of Weimer (1955, p. 146). However, southeast of the pass, Childers (1963, pl. 1) showed Jurassic and Mississippian rocks truncated by a younger thrust fault. These 

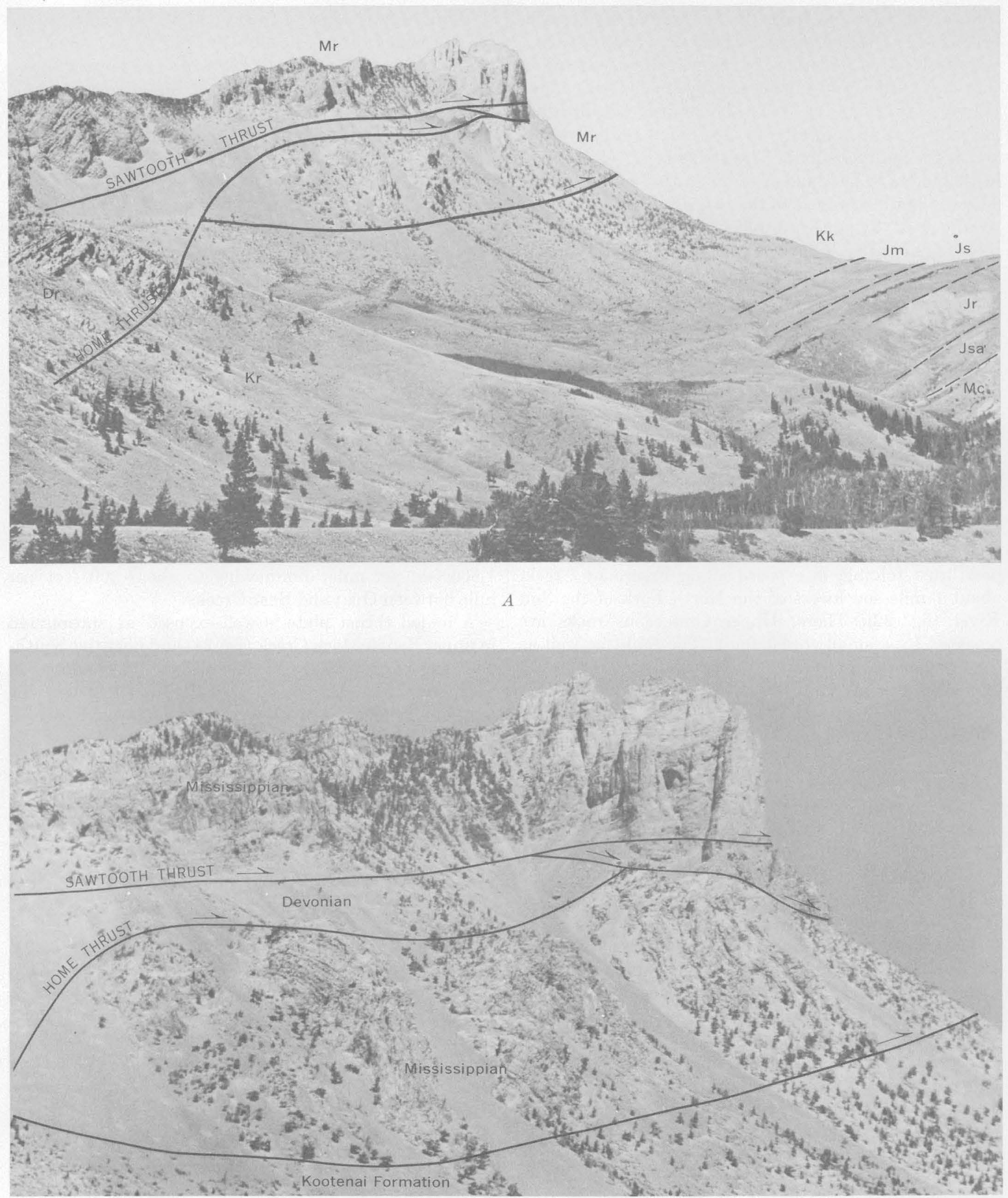


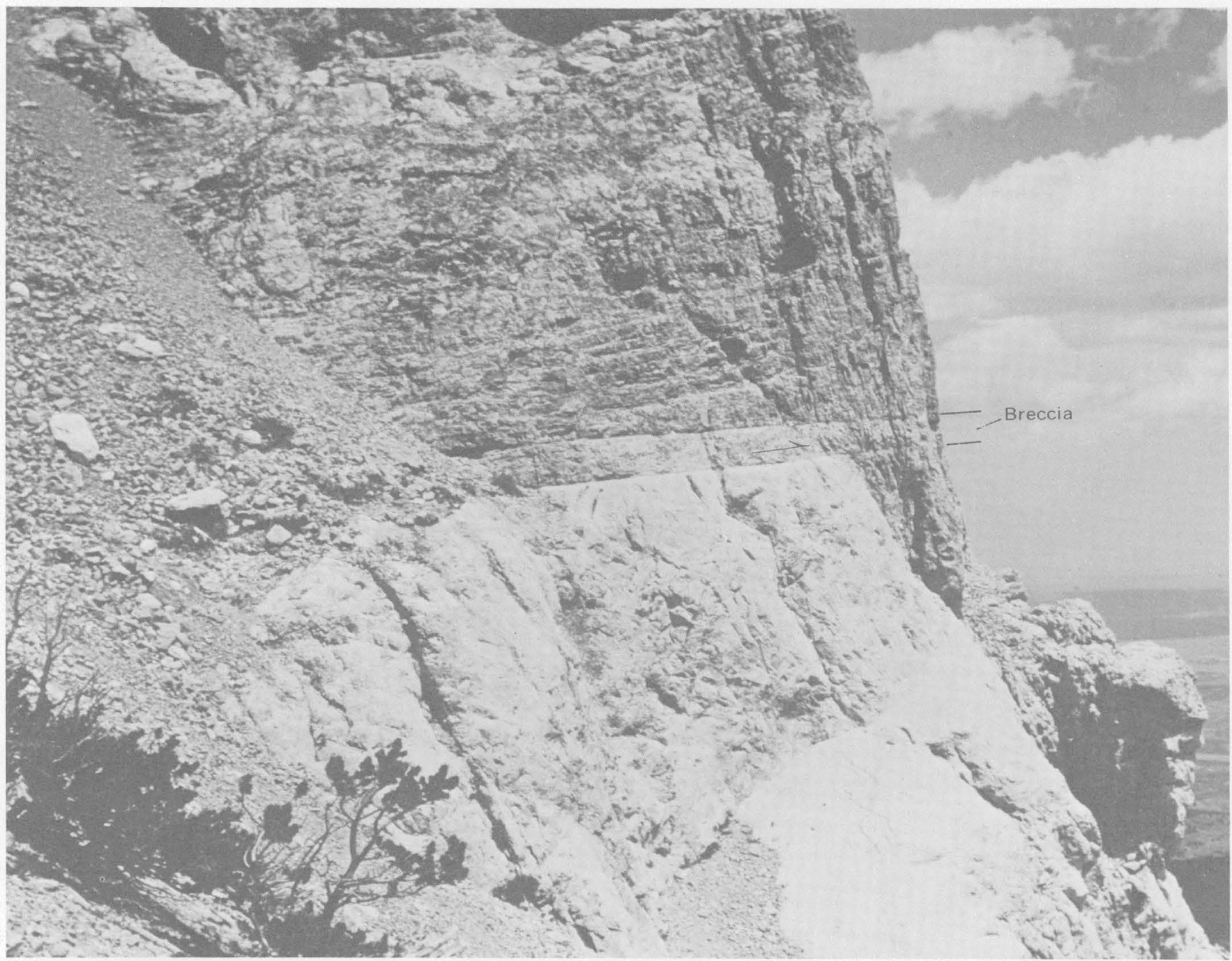

C

Figure 17.-Geology of Wagner Basin and the south end of Castle Reef.

$A$, Looking north at Wagner Basin and the south end of Castle Reef. Dr, Devonian Jefferson and Three Forks Formations; Mr, Mississippian rocks; Mc, Castle Reef Dolomite; Jsa, Sawtooth Formation; Jr, Rierdon Formation; Js, Swift Formation; Jm, Morrison Formation; Kk, Kootenai Formation; $\mathrm{Kr}$, Lower Cretaceous rocks. $B$, Closeup of upper reaches of Wagner Basin and south end of Castle Reef. Note the easterly dipping Mississippian strata above the lower thrust.

$C$, Closeup of the southeasternmost spire of Castle Reef (shown in $A$ and $B$ ), where the Sawtooth thrust joins the Home thrust. The light-gray beds of the Castle Reef Dolomite dip steeply eastward. The overlying dark-gray beds of the middle member of the Allan Mountain Limestone dip about $15^{\circ} \mathrm{W}$.; the fault dips $5^{\circ} \mathrm{W}$. The breccia consists mostly of limestone from the Allan Mountain. 

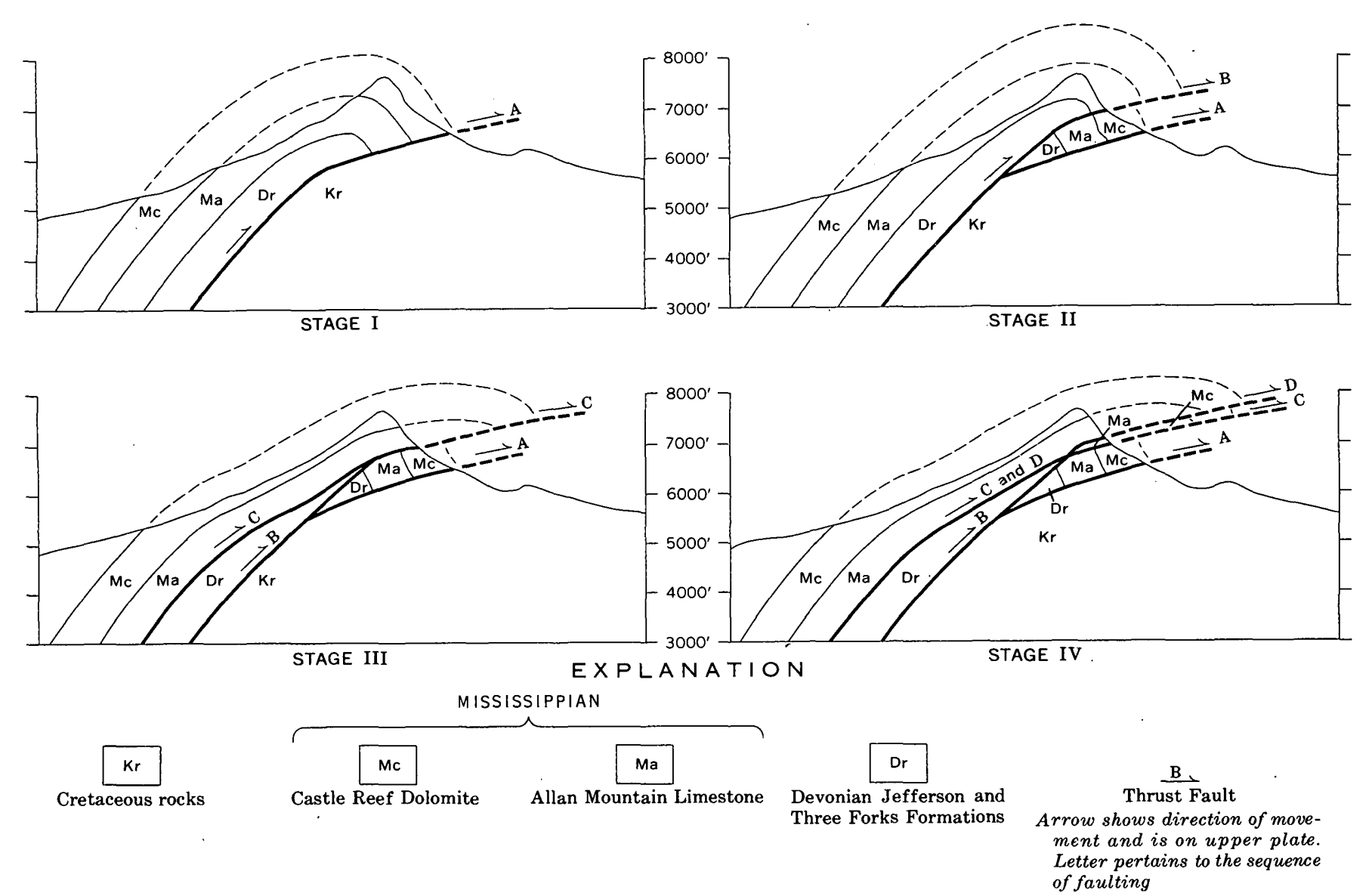

Figure 18.-An interpretation of the development of the structure at the south end of Castle Reef. A, Home thrust;

rocks are very likely part of a northern extension of subbelt VI in the Sun River Canyon area. Subbelt VI persists at least as far south as Elk Creek, about 20 miles south of this area.

The strike of the thrust plate changes markedly at the West Fork of the Sun River, from about N. $10^{\circ}-$ $15^{\circ} \mathrm{W}$. to the north to N. $45^{\circ} \mathrm{W}$. to the south.

The small folds are associated with thrust faults. Just north of the West Fork of the Sun River, a syncline and an anticline in Jurassic rocks strike S. $70^{\circ}-80^{\circ}$ E., almost at right angles to the trend of the thrust plate (Mudge, 1966b). This discordance suggests that a horizontal couple probably existed in the thrust plate. These folds may have formed during the movement on the South Fork thrust zone (subbelt VII) just southwest, as they parallel that zone.

The Renshaw thrust bounds subbelt VI on the east. At Sheep Mountain, it truncates two older fault blocks in subbelt V. There, the lower 100 feet of Mississippian rocks is distorted and brecciated. The Renshaw thrust has a stratigraphic throw of about 4,000 feet, and it dips $20^{\circ}-30^{\circ} \mathrm{W}$. Near the South Fork of the Sun
B, subsequent thrust; C, Sawtooth thrust; D, younger minor thrust. Horizontal scale same as vertical scale.

River, it dips more steeply than the overlying strata. The older strata that comprise the sole of the block in this topographically low area are absent from nearby higher areas. Farther south, the rocks above the Renshaw thrust are so complexly faulted and folded that they are shown as undifferentiated Mississippian rocks on plate 1 in chapter A (Mudge, 1972).

Overturned Mississippian and Jurassic rocks make up the western side of the highest plate in subbelt VI along the West Fork of the Sun River (pl. 1; Mudge 1972 , pl. 1). In the river narrows, the Mississippian rocks are brecciated and in places much sheared and faulted. However, just south of the river, the members of the two overturned formations are well enough preserved to be mapped. Their arrangement indicates that they were originally in an overturned fold that was subsequently faulted, probably during the movement of the higher South Fork thrust zone of subbelt VII, which has truncated the overturned sequence. The relationship between the overturned strata and the South Fork thrust zone is further discussed later in this report in connection. with the mechanics of thrust 


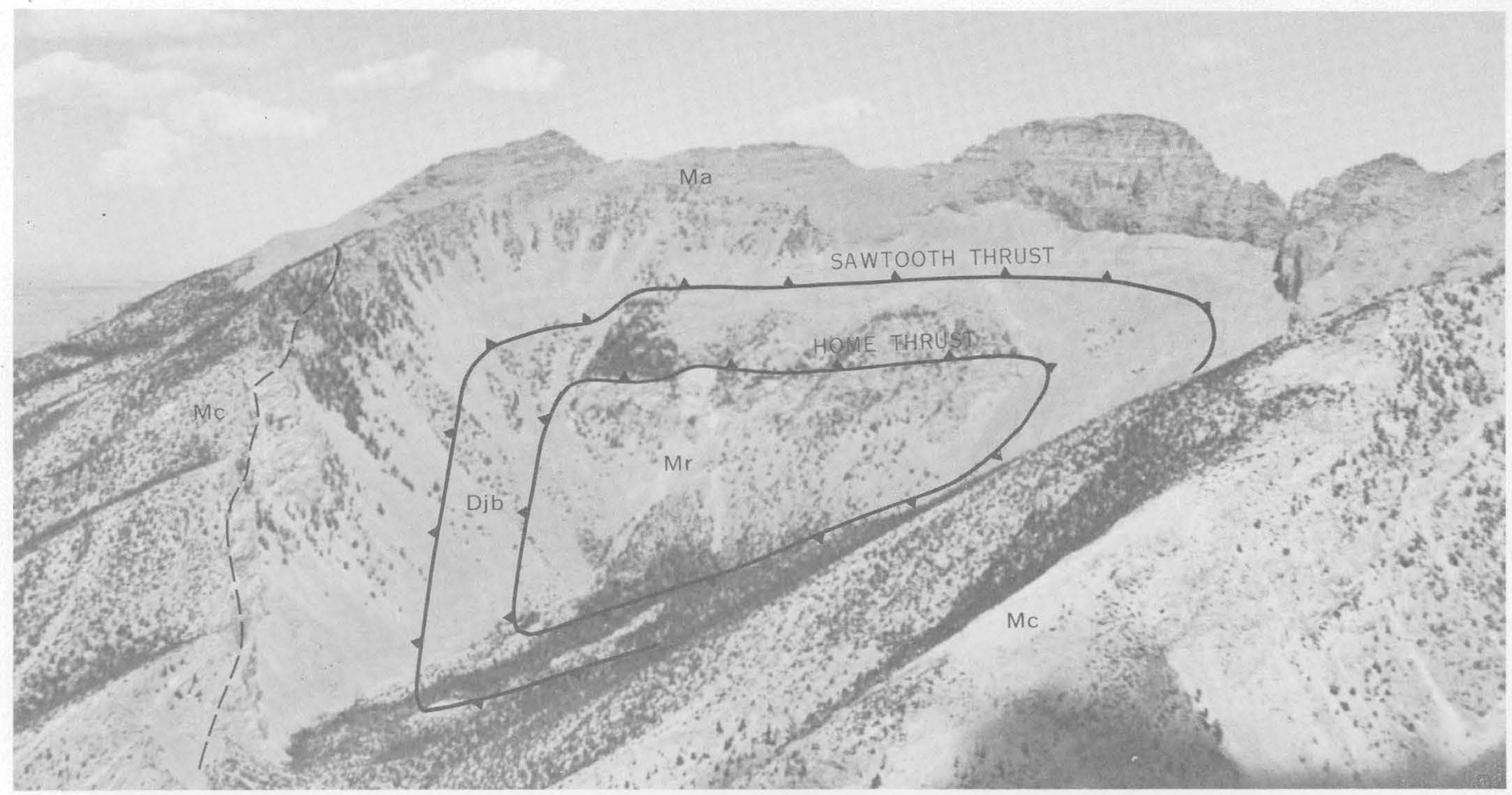

Figure 19.-A double fenster in a large cirque on the west side of Sawtooth Ridge. The same structural relations shown here are also exposed on the east side of Sawtooth Ridge (frontispi ece). Dib, Birdbear Member of the Jefferson Formation; Mr, Mississippian rocks undivided; Ma, Allan Mountain Limestone; Mc, Castle Reef Dolomite.

faulting. As far away as Wolf Creek, Mont., about 45 miles to the southeast, many thrust blocks of Mississippian rocks lie beneath the easternmost thrust of subbelt VII.

Small thrust faults repeat some of the Jurassic rocks, as in subbelt III (Mudge, 1972, pl. 1). Near the West Fork of the Sun River, most of the repeated strata are of the Rierdon Formation. To the south, rocks of the Morrison Formation are repeated in thrust plates of the eastern part of an imbricate thrust zone, In the western part of this zone, strata of the Kootenai Formation and the Flood Shale Member of the Blackleaf Formation are repeated across the many faults.

\section{SUBBELT VII}

Subbelt VII, which averages about 2 miles in width, lies along the west side of the Sun River Canyon area (fig. 5). It consists mostly of one major thrust block of Precambrian rocks overlain by Cambrian, Devonian, and, locally, Mississippian rocks. In places, the block is offset by normal faults and smaller thrusts. The basal part is cut into many plates by the imbricate South Fork thrust zone, which is only locally exposed above the sole thrust. Subbelt VII correlates with zone 5 of Weimer (1955, p. 146), along the south edge of Glacier National Park, and with part of the western subdivision of Childers (1963, p. 154). The structures in subbelt VII trend N. $15^{\circ} \mathrm{W}$. in the northern part of the area, due north in the central part, and N. $40^{\circ}$ W. $\mathrm{N} .80^{\circ} \mathrm{W}$. in the southern part, averaging about N. $45^{\circ} \mathrm{W}$. Near Deadman Hill, in the eastern part of this subbelt, small open folds, a broad asymmetrical syncline, and a small anticline parallel the trend of the subbelt.

\section{SOUTH FORK THRUST ZONE}

The South Fork thrust zone is an imbricate zone in most places in the area. Many workers have referred to it as the Lewis thrust, assuming that it is the extension of the classic Lewis thrust in Glacier National Park (Clapp, 1932, p. 25; Deiss, 1943a, p. 250). Some (for example, Clapp, 1932, p. 25) also connect the Lewis thrust with the Lombard thrust to the southeast in the Holder Lake-Three Forks area.

The relationship between the Lombard, South Forks and Lewis thrusts cannot be determined from present data (fig. 2). The overlying plates of these three thrusts contain Precambrian (Belt) rocks generally resting on Mesozoic rocks. At Marias Pass the Lewis thrust is truncated by the Blacktail fault (Childers, 1963, pl. 1), a normal fault along the east side of Flathead Valley; south of the pass, small local remnants of the Lewis thrust plate lie east of the Blacktail fault (Childers, 1963, pl. 1). This thrust plate has not been 


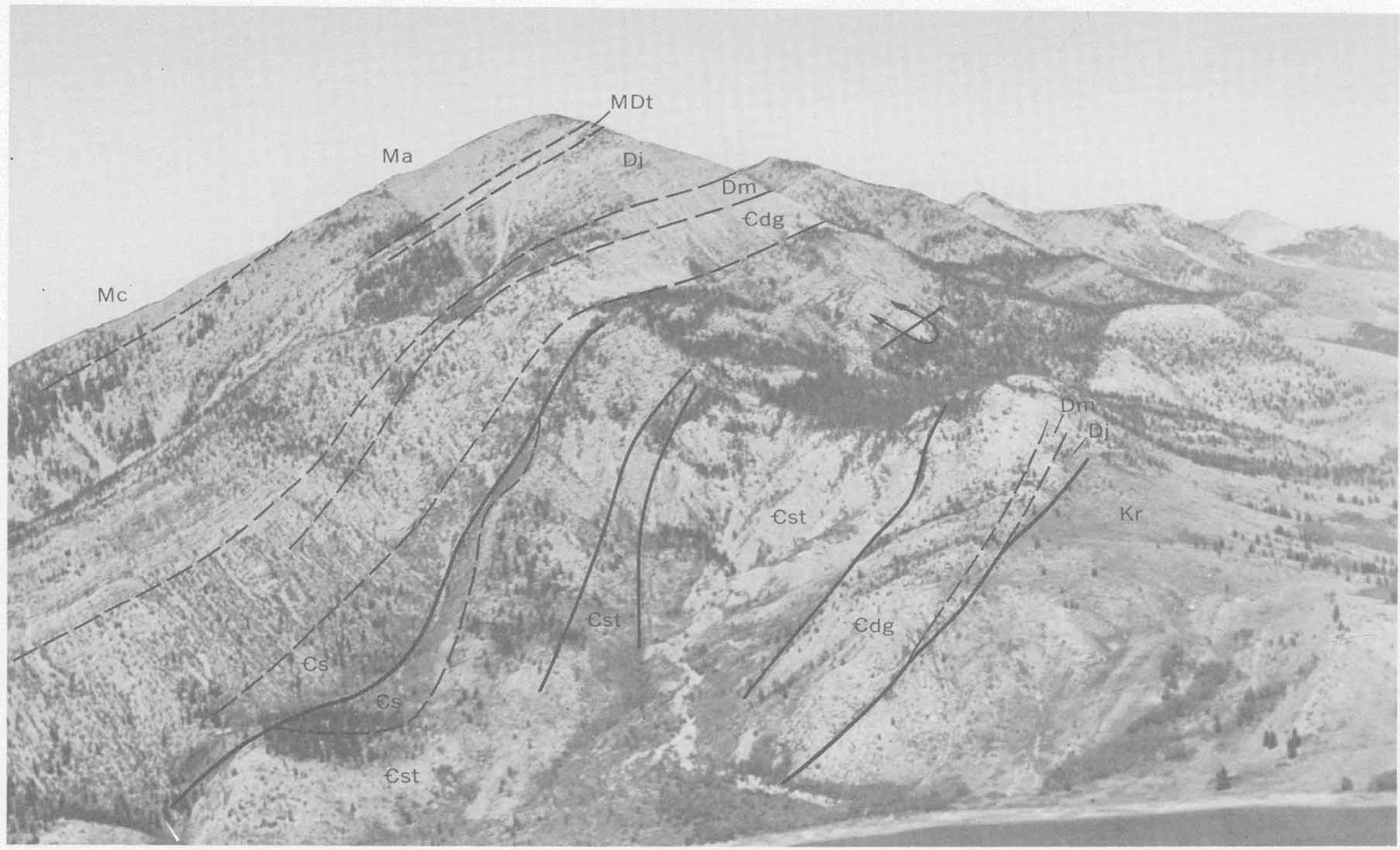

Figure 20.-Aerial view of ridge west of Big George Gulch and north of Gibson Reservoir. The Paleozoic rocks are in a large overturned anticline which is thrust (solid line) over Cretaceous rocks. Many younger thrusts (solid lines) have repeated some of the incompetent Cambrian strata in the interior of the fold. €st, Steamboat Limestone; €s, Switchback Shale; €dg, Devils
Glen Dolomite; Dm, Maywood Formation; Dj, Jefferson Formation; MDt, Three Forks Formation; Ma, Allan Mountain Limestone; Mc, Castle Reef Dolomite; and Kr, Lower Cretaceous rocks. The Taft Hill Member of the Blackleaf Formation underlies the thrust fault.

thrust in subbelt VII at different places along strike. The relationship of the thrust plates in the Dearborn River area to the Lombard thrust south of the Wolf Creek area is unknown.

Numerous thrust faults comprise the South Fork thrust zone in the Sun River Canyon area (pl. 1; Mudge, 1972, pl. 1). The sole fault generally rests on Lower Cretaceous rocks, although locally it rests on Mississippian rocks. The probable relation between the Mississippian rocks in the western part of subbelt VI and the South Fork thrust zone is discussed on page 40. The easternmost thrust of the zone has a stratigraphic throw of more than 14,000 feet and a minimum horizontal movement of 4 miles. Deiss (1943a, p. 250) estimated that near the South Fork of the Sun River this thrust had a stratigraphic displacement of about 12,000 feet and a slip of as much as 7 miles. South of the Sun River Canyon area, Clapp (1934) estimated that this thrust had an average dip of $18^{\circ}$, a stratigraphic displacement of 5,000-15,000 feet, and a slip of at least 6 miles. The younger thrust faults in the South the thrusting and that different Precambrian fault plates overlie the easternmost exceptionally large 


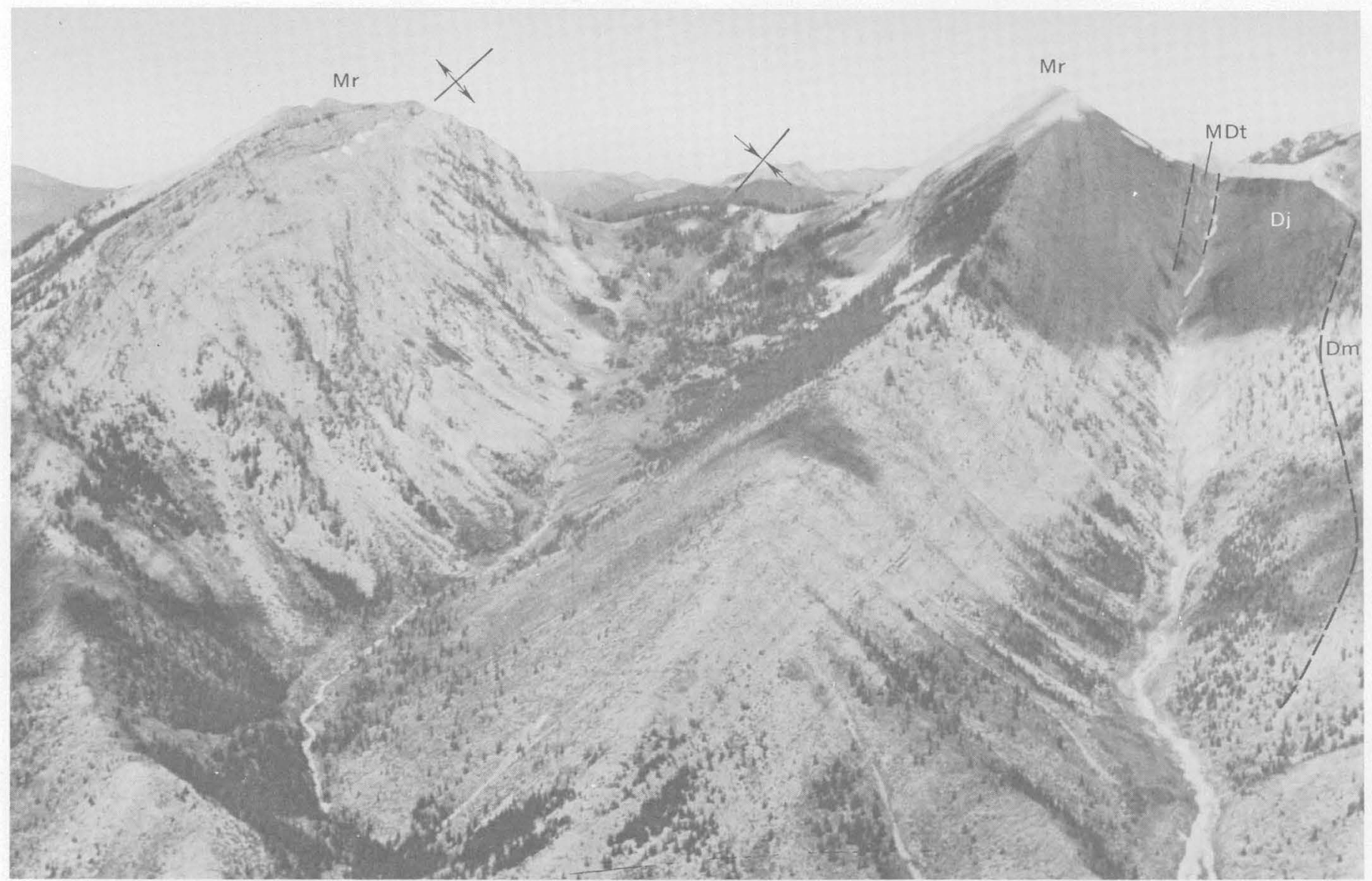

Figure 21.-View looking north at Beartop Mountain (left peak), north of Biggs Creek, showing an asymmetrical chevron anticline at Beartop and an asymmetrical syncline in the valley to the right (east). The west limb of the anticline dips $36^{\circ} \mathrm{W}$., the east limb $70^{\circ}-80^{\circ}$ E. (Deiss, 1943 b, p. 1158). Deiss noted that the crest of the anticline is broken by a small thrust fault. Dm, Maywood Formation; Di, Jefferson Formation; MDt, Three Forks Formation; Mr, Mississippian rocks undifferentiated.

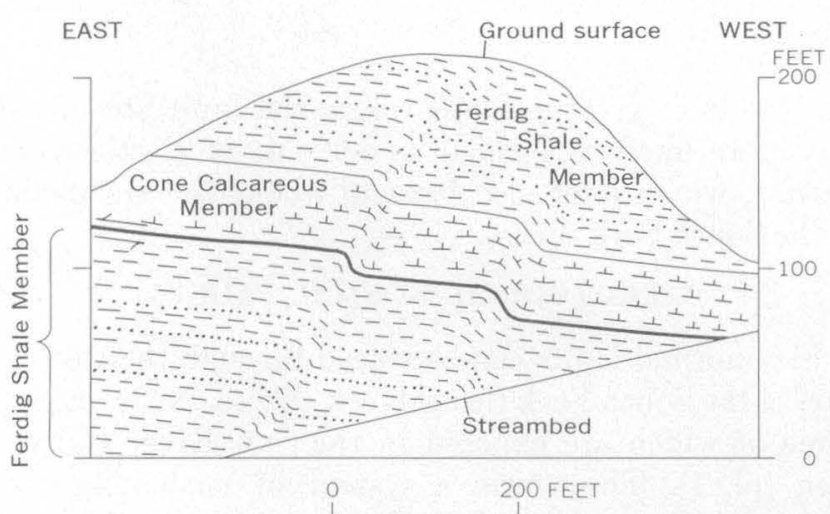

Figure 22.-Folded thrust plate in the Cone Calcareous and Ferdig Shale Members of the Marias River Shale exposed in a streambank along Freezeout Creek, about 1 mile southwest of the North Fork of the Sun River.

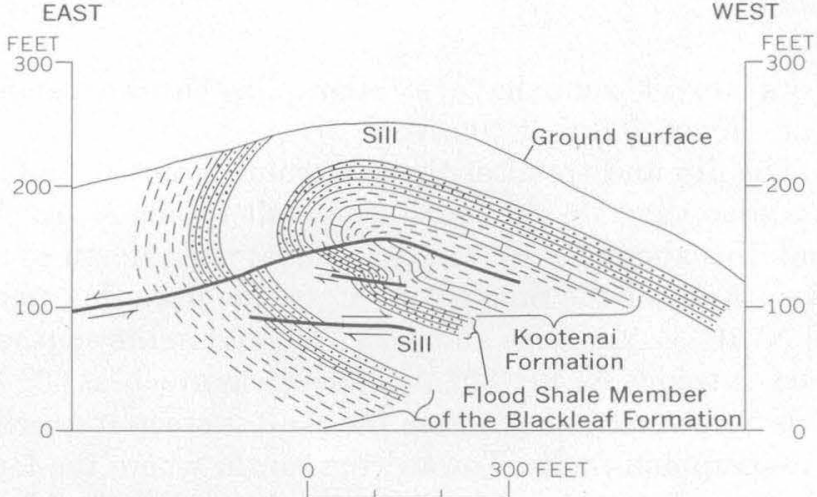

Figure 23.- Recumbent fold, small thrust, and two reverse thrusts in subbelt V at station 205 (pl. 1), south of Moose Creek. 


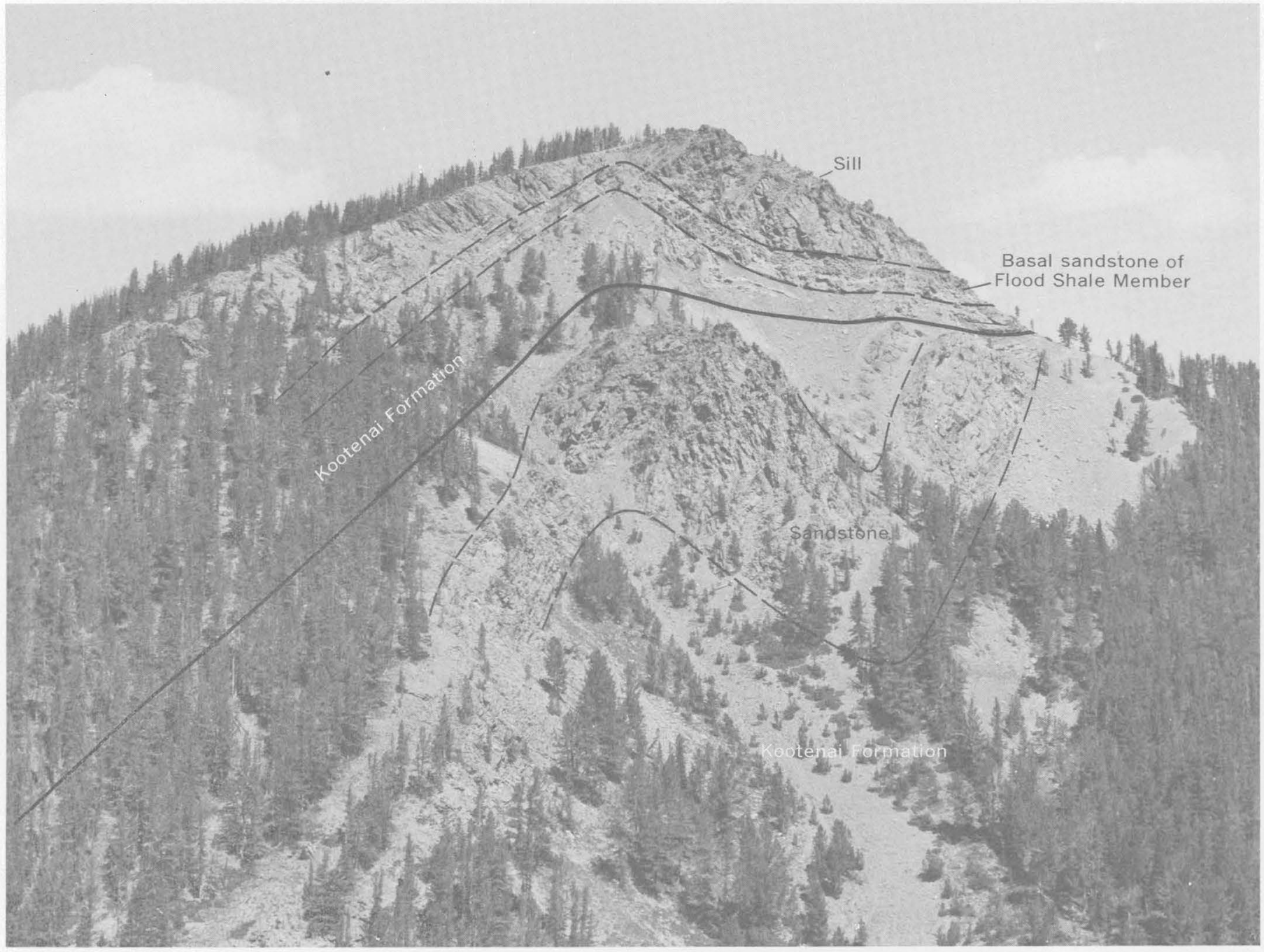

Figure 24.-Folded thrust plate on the north side of the upper reaches of Bench Mark Creek (sta. 146 pl. 1). Small drag folds have thickened the Kootenai Formation in the crestal area above the fault. The syncline in the lower plate probably formed during thrusting by the flowage of the mudstone above the sandstone. The anticline which affects both plates also was formed during thrusting.

Fork thrust zone have stratigraphic throws ranging from about 500 to 1,500 feet.

The dip and trend of the easternmost thrust fault in the zone vary. In the north, the fault trends N. $15^{\circ} \mathrm{W}$. and dips about $10^{\circ} \mathrm{W}$.; in the central part, north of the West Fork of the Sun River, it trends from due north to N. $10^{\circ} \mathrm{E}$. and dips about $25^{\circ} \mathrm{W}$.; and in the southern part, it trends N. $40^{\circ}-80^{\circ} \mathrm{W}$. and dips as much as $60^{\circ} \mathrm{W}$. It is noteworthy that where the fault is steep it overlies Mississippian rocks. Toward the south, where the fault dips steeply, an imbricate zone has formed in the Mesozoic rocks in subbelt VI to the northeast. Farther north, where the fault dip is lower, the Mesozoic rocks to the east are virtually undisturbed. This suggests a possible relation between the steepness of the fault and the imbricate zone. The imbricate zone may have formed as the result of greater stress where the fault steepened, but more likely it formed as a result of a subsurface barrier, which later also brought about the steepening of the South Fork thrust.

\section{LONGITUDINAL NORMAL FAULTS}

Five normal faults can be traced through the western part of the South Fork thrustblock (Deiss, 1943a, p. 251), three of which are exposed in the Sun River Canyon area (pl. 1). They form a system of coalescing step faults, with successive downthrown blocks to the west. This fault system resembles an arcuate landslide block, bowing toward the east, and the faults are very likely "listric normal faults" like those described by Bally, Gordy, and Stewart (1966, p. 355). Most of the faults coalesce to the south. In addition, the easternmost one 
(the Glenn fault) dips at a moderately low angle to the west, and each subsequent fault has a somewhat steeper dip than the fault east of it. The Glenn fault rotated the downthrown block in which the strata dip easterly.

The Glenn fault was described by Deiss (1943a, p. 251) as a normal fault with a dip of $5^{\circ}-7^{\circ}$. Such low dips were not observed by me. In the ridge north of the South Fork of Glenn Creek, the fault trends N. $40^{\circ}$ E. and dips about $30^{\circ} \mathrm{W}$. In Glenn Creek, it displaces a thrust of the South Fork zone, dropping the Bonner Quartzite alongside the sandstone member of the Mount Shields Formation (Mudge, 1966c), a displacement of about 1,000 feet. Both north and south, the displacement diminishes to about 600 feet. Near Bear Lake on the south and in Moose Creek valley on the north, the Glenn fault coalesces with the next normal fault to the west. Both areas are covered by Quaternary deposits, and Deiss (1943a, p. 251) believed that the Glenn fault is eut by the western fault rather than coalescing with it. The pattern of the faults, however, indicates that they do coalesce and that they resulted from relaxation of the stresses that created the thrust faults.

The fault west of the Glenn fault is the largest and longest of the five normal faults; it extends at least 13 miles from Prairie Reef north across Red Shale Creek (fig. 25). At Prairie Reef, it trends N. $80^{\circ}$ E. and has a displacement of less than 300 feet. In the ridge south of the upper reaches of the South Fork of Glenn Creek, it trends $\mathrm{N} .3^{\circ} \mathrm{E}$. and dips $70^{\circ} \mathrm{W}$. It dropped the Steamboat Limestone alongside basal beds of the Bonner Quartzite, a displacement of about 2,500 feet (fig. 25). To the north on Slategoat Mountain, the fault trends N. $15^{\circ} \mathrm{W}$., and there it brought the lower beds of the Allan Mountain Limestone down to the Pagoda Limestone, also a displacement of about 2,500 feet (fig. 26).

A third normal fault coalesces with the second in the upper reaches of the South Fork of Glenn Creek (fig. 25). This fault trends N. $60^{\circ} \mathrm{W}$. and dips about $80^{\circ}$ W., with a displacement of about 300 feet. Two

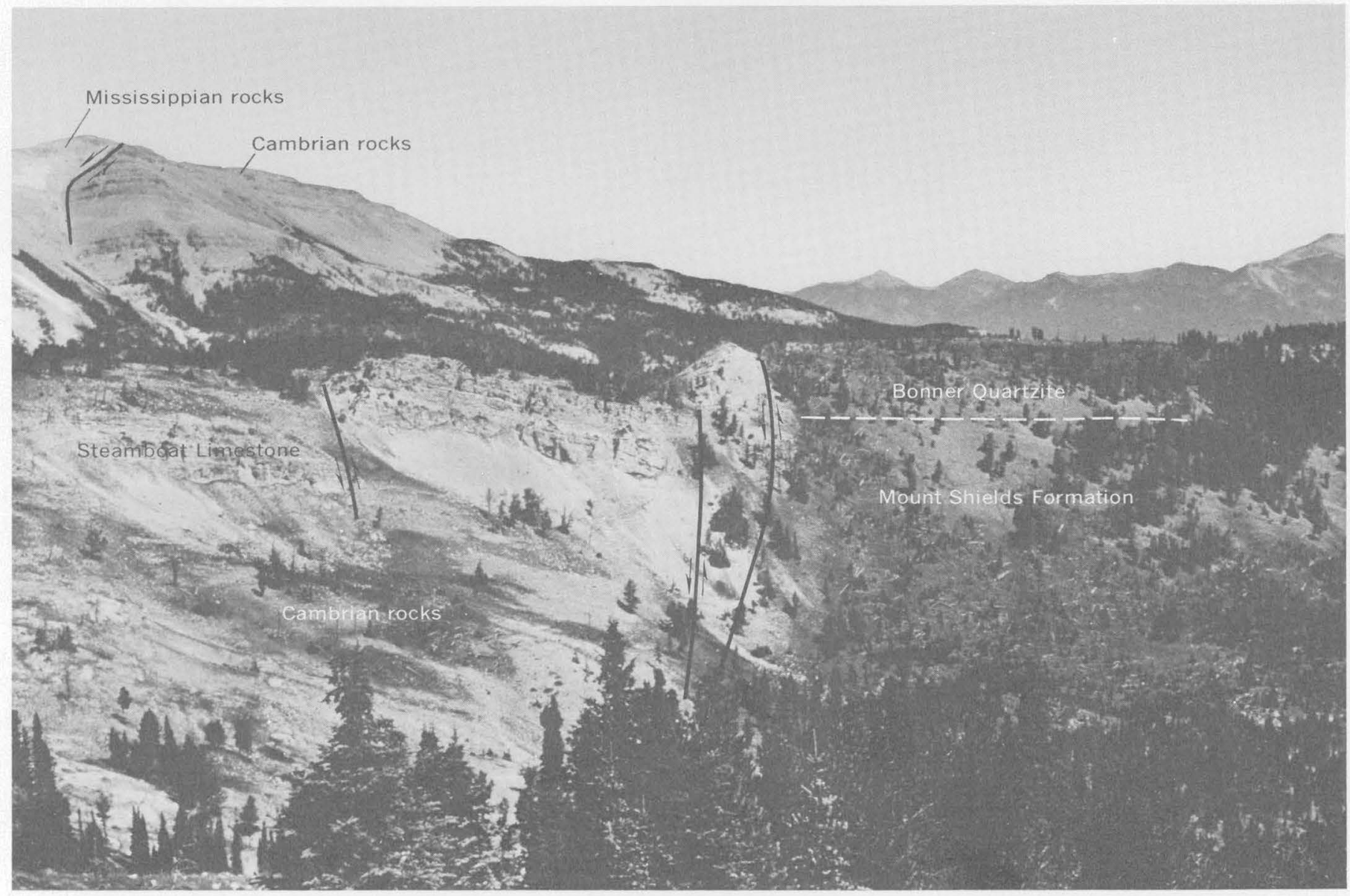

Figure 25.- - Longitudinal normal fault in upper South Fork of Glenn Creek (viewed to the north). The Steamboat Limestone is in the downthrown block (west), alongside the Bonner Quartzite, displaced about 2,500 feet. The mountain in the upper left eorner is the north end of Slategoat Mountain. There, the normal fault extends through the crest of the mountain (fig. 26). 


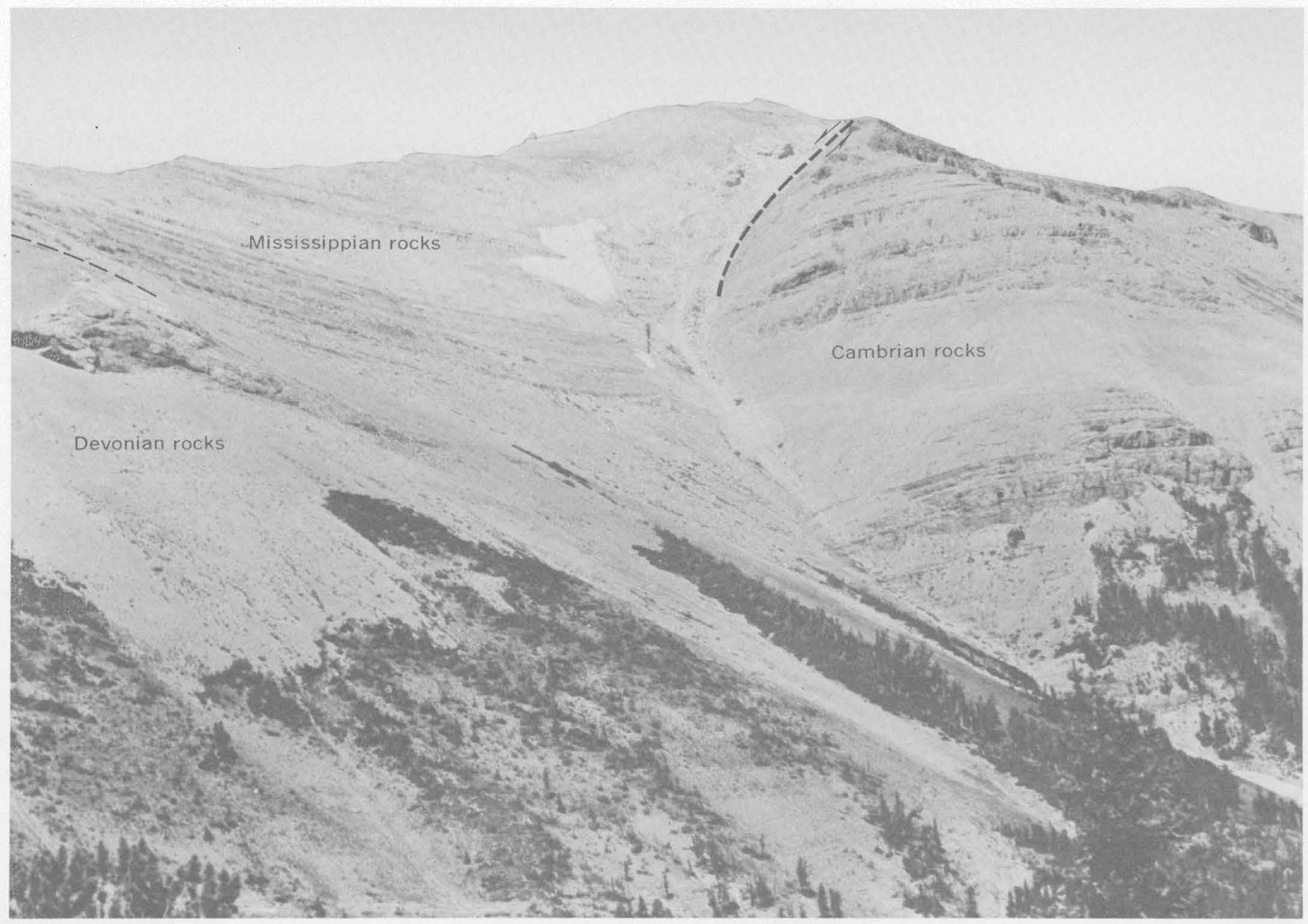

Figure 26.-Telephotographic view (looking north) of the crest of Slategoat Mountain. The gully is incised along the longitudinal normal fault. The downthrown block (left) contains Mississippian (light gray) and Devonian rocks (medium gray). Cambrian rocks comprise the upthrown block to the right.

other small steeply dipping normal faults were observed west of the third one.

\section{SUBBELT VIII}

Subbelt VIII, about 2 miles wide, extends across the southwest corner of the mapped area (fig. 5). This subbelt, like subbelt VII, is one thrust fault block; it is made up of Precambrian and Cambrian rocks and persists southward at least 25 miles to the Dearborn River. It is part of the western subdivision of Childers (1963, p. 154).

The subbelt is bounded on the east by a large thrust zone and on the west by a large thrust fault of subbelt IX. A longitudinal normal fault and two small tear faults are along the west side. The block is folded into an anticline and syncline near Crown Mountain, south of the area (McGill and Sommers, 1967, p. 346). Both are asymmetrical, with axial planes inclined to the west.
The basal West Fork thrust zone generally contains three thrust faults but locally only one (pl. 1). I have traced the faults as far south as the Dearborn River and as far northwest as lat $48^{\circ} 00^{\prime}$ (fig. 1). The lowest thrust fault in the West Fork thrust zone dips about $25^{\circ} \mathrm{SW}$; its stratigraphic throw is about 1,500 feet. To the northwest, at the south end of Prairie Reef, this fault truncates the Precambrian and all the Cambrian and Devonian strata of the upper part of subbelt VII (fig. 1). Farther north, at Moose Creek, it dips $15^{\circ}$ W. and has a stratigraphic throw of at least 6,000 feet. The West Fork thrust zone trends about $55^{\circ} \mathrm{NW}$., virtually parallel to subbelt VII in this area.

The longitudinal normal fault on the southwest side of Nineteen Mountain is truncated to the north by the thrust of subbelt IX. The normal fault trends N. $55^{\circ}$ W., nearly parallel to the other structures. The downthrow of about 650 feet is to the southwest. 
Two small tear faults displace Cambrian rocks at Nineteen Mountain. Both trend about N. $20^{\circ}$ E. and are right-lateral slip faults with shifts of less than 100 feet.

\section{SUBBELT IX}

Only a very small part of subbelt IX falls within the southwest corner of the mapped area (fig. 5). However, this subbelt is much more extensive, as interpreted from unpublished maps of the Coopers Lake and Silvertip quadrangles by Charles Deiss. The fault block is known to extend from a point west of Wolf Creek northwest at least as far as the West Fork of the Sun River (fig. 1). Subbelt IX is bounded on the east by the westernmost thrust fault of the disturbed belt. It is also shown on maps by Sommers (1966), McGill and Sommers (1967, p. 346), Viele (1960), and Mudge, Erickson, and Kleinkopf (1968). Much of the information on subbelt IX was derived from the above sources. The thrust fault along the eastern margin of subbelt IX, in upper Dearborn River, dips $45^{\circ} \mathrm{W}$. and has a stratigraphic throw of about 6,000 feet.

The trend of subbelt IX parallels that of subbelts VI and VII. Subbelt IX trends N. $45^{\circ}$ W. from Dearborn River northwest through the southwest corner of the Sun River Canyon area to the West Fork of the Sun River.

Several large normal faults are traceable along the east side of the South Fork of the Flathead River (Ross and others, 1955; Johns, 1964; Sommers, 1966). 'The longest, a high-angle northivest-trending normal fault, has about 16,000 feet of dip separation downthrown to the west (Sommers, 1966, p. 84).

\section{MECHANICS OF THRUSTING AND FOLDING}

The tectonic development of the disturbed belt during the early Tertiary orogeny has long been recognized to be a result of compressional forces whose principal stress was from the west. The concept of vertical uplift to the west that caused folds and thrust faults as secondary features formed by gravitational gliding was applied to the northern part of the area by me (1970). ${ }^{1}$ The compression may have resulted from uplift and gravitational gliding, as discussed by Rubey and Hubbert (1959, p. 199-200). Five episodes of the orogeny are recognized in this report, each of which may reflect a period of renewed uplift in the west (Mudge, 1970). Each began with a compressional phase, and most ended with a tensional phase. The factors controlling

1 After this report was written, Price and Mountjoy (1970) and Price (1971) provided an alternate hypothesis for the origin of the structures in the eastern Cordillera of Canada. Their (1970) hypothesis suggests lateral gravitational spreading from a zone of upwelling in a hot, mobile, metamorphic infrastructure of the core of the eastern corne proposed in my 1970 paper. the structure included composition of the rocks, zones or horizons of weakness, mode of fracturing or shearing, ability of the rocks to flex or flow, and amount of overburden. Many of the large thrust faults in the area originated from fractures that probably developed in the east limb of overturned anticlines.

\section{EPISODES OF THE OROGENY}

At least five structural episodes during the orogeny are recognizable in and near the Sun River Canyon area; others may have occurred but are no longer recognizable. Each episode may reflect a period of uplift to the west that contributed gravitational-slide blocks to the east (Mudge, 1970). Each episode consists of a compressional phase terminated by a tensional or relaxational phase. The compressional phases are represented by the northerly trending folds and westerly dipping thrust faults; the tensional, or relaxational, phases are represented by northerly trending westdipping normal faults. The sequence of events indicates that deformation in the Sun River Canyon area was like that in Utah, where Nolan (1935, p. 55) recognized similar cycles.

Episode 1.-This first, and least clearly defined, episode is represented by structures in subbelt I. Compression during this episode of deformation formed many folds, some of which were broken by small high-angle thrust faults. This episode is particularly evident to the north in the Two Medicine-Badger Creek area, where the easternmost structures trend about N. $20^{\circ}$ W. rather than N. $55^{\circ} \mathrm{W}$. as in the next subbelt to the west (Weimer, 1955, p. 146). The relaxation of stress during this early episode permitted formation of the longitudinal normal faults in the western part of subbelt I (fig. 7).

Episode 2.-Compression during the second episode created the structures in subbelts II and III. Folding occurred either during the first episode or in the early stages of this episode. These folds were later broken by thrust faults that formed sole thrusts. Additional folding and thrust faulting formed most of the structures in these subbelts. This episode was ended by a relaxation of stress, during which a longitudinal normal fault (the Elk fault) formed along the west boundary of subbelt II.

Episode 3.-Compression during the third episode formed the structures in subbelts IV, V, VI, and VII. This episode began with folding in subbelt IV and continued with thrust faulting. The intensity of thrusting gradually increased through subbelts $\mathrm{V}$ and VI and culminated in an exceptionally large low-angle thrust in subbelt VII. During relaxation of stress, many low-angle westerly dipping longitudinal normal faults, of which the Glenn fault is the easternmost, were formed 
(fig. 25). All these normal faults are in the western part of subbelt VII.

Episode 4.-Compression during the fourth episode formed the structures in subbelt VIII. It is uncertain whether or not folding preceded thrusting. A syncline adjoining the West Fork thrust zone may have formed during this episode. The long travel of the West Fork thrust and subsequent erosion may have removed most of the evidence of an anticline. Other folds in this subbelt in the Crown Mountain area to the south may have formed during or shortly after thrusting. During a relaxation of stress, the westerly dipping longitudinal fault west of the peak at Ninteen Mountain was formed.

Episode 5.-Compression during the fifth episode formed the structures in subbelt IX. The evidence of folding is similar to that for episode 4. A large syncline is present in this subbelt just west of the Continental Divide (fig. 1). The westernmost large thrust fault lies east of the syncline. The syncline is assumed to have formed by compression prior to the thrust fault. The large longitudinal normal faults in the western part of subbelt IX are post thrust faults (Mudge, 1970). The fault along the east side of the South Fork of the Flathead River may have formed during the relaxation of the compressive stresses of the episode.

\section{STRESS VECTORS}

Two major stress vectors that were responsible for the structural trends in the Sun River Canyon area are reflected in the trends of thrust and normal faults and folds. This evidence indicates that the stress was mainly from the west in the northern part of the area and mainly from the southwest in the southern part (pl. 1). All the thrust faults dip westward, and almost all the fold axes parallel the thrust faults. The asymmetrical folds all have the steepest flank to the east, toward which many are overturned.

During the first episode of deformation, the stress vectors were more uniform than during the later four episodes. As mentioned previously, in the area east and southeast of Glacier National Park, the structures of the first episode trend more nearly northerly than those of subsequent episodes (fig. 1). South of the Sun River Canyon area, however, they trend more to the east than those of the later episodes, if we assume that the easternmost structures near the Little Belt Mountains were formed during the earliest episode. The strong stress vector south of the Sun River Canyon area was directed easterly around the Boulder batholith, as is evident from the geologic map of Montana (Ross and others, 1955).

The trend of the structures in the Sun River Canyon area differs not only from south to north but also from east to west (pl. 1). In the eastern subbelts (subbelts $\mathrm{I}-\mathrm{V})$, the structures south of the Sun River trend mostly from N. $10^{\circ} \mathrm{W}$. to N. $20^{\circ} \mathrm{W}$., and those north of the river trend almost due north. The Sun River is incised along this east-west line of flexure. In the western subbelts (subbelts VI-IX), the trends south of the West Fork of the Sun River are from N. $45^{\circ} \mathrm{W}$. to N. $80^{\circ} \mathrm{W}$., and those northward are from N. $35^{\circ} \mathrm{W}$. to due north. The West Fork is incised along this eastwest change in trend. This line of flexure is $53 / 2$ miles south of that in the eastern five subbelts.

The abrupt changes in trend between the Sun River and the West Fork of the Sun River lines of flexure may be attributed to a later renewal of stress in which the dominant stress was from the southwest. If the change in direction was gradual, any evidence has been completely obliterated by the Renshaw thrust (the eastern fault of subbelt VI). The abrupt change in trends suggests that part of the record of an episode may be missing; perhaps subbelts IV and V represent a separate distinct episode rather than a part of episode 3 .

\section{SEQUENCE OF DEFORMATION}

Whether deformation advanced from east to west or from west to east is not easily determined. Most workers in the disturbed belt of Montana have favored a sequence of deformation from east to west-that is, the oldest structures are on the east side of the belt and the youngest are on the west. But in Alberta, many recent workers favor the opposite sequence. Clearly, the sequence is important in any discussion of the mechanics of folding and thrusting.

The sequence considered should, of course, be within a single orogeny. The structures in the northern part of the disturbed belt in Montana were all formed between early Paleocene and late Eocene. In the IdahoWyoming disturbed belt, on the other hand, the westto-east sequence of structures was formed in five separate episodes between the Late Jurassic and the early Eocene (Rubey and Hubbert, 1959, p. 190; Armstrong and Oriel, 1965, p. 1859-1861). Thus, the eastern thrust faults in Wyoming - the Darby, Prospect, Hogsback, and La Barge faults-are equivalent in age to the structures of the northern part of the disturbed belt of Montana.

In the Sun River Canyon area, the sequence of deformation proceeded from east to west, according to all available data. Many westerly faults truncate parts of one or more fault blocks to the east (pl. 1; Mudge, 1972 , pl. 1). In general, the amount of deformation increases from east to west. The sequence from east to west mostly progresses from a broad syncline through 
(1) open symmetrical folds, (2) asymmetrical or overturned folds with many small high-angle thrust faults, (3) large moderately low angle thrust faults, and (4) exceptionally large low angle thrust faults. The dips of the faults vary most in the Sawtooth Range.

Deiss (1943a, p. 249, 256) believed that the oldest faults are in the eastern part of the Sawtooth Range and that the youngest fault is the Lewis "overthrust" (South Fork thrust zone), to the west, because the Lewis thrust truncates the westernmost high-angle thrust of the Sawtooth Range. His observations are verified because the South Fork thrust zone truncates Mississippian and Cretaceous strata in many places in the western part of the area (Mudge, 1972, pl. 1). To the south, older fault blocks are also truncated by this exceptionally large fault (McGill and Sommers, 1967, fig. 2; Mudge and others, 1968; Viele, 1960). To the north, in the area south of Marias Pass and Glacier National Park, Childers (1963, pl. 1) showed the Lewis thrust abruptly truncating Paleozoic and Mesozoic rocks of the Sawtooth Range. In the Dearborn River area, Viele (1960, p. 183) also concluded that faulting along the front of the mountains developed from east to west.

The preceding data are contrary to those of some workers in Alberta, where the order of deformation is believed to have proceeded from west to east (Hume, 1957, p. 401; Scott, 1951, p. 2346; Bally and others, 1966 , p. 370). Others, however, favor an east-to-west development of the structures (Douglas, 1950, p. 94; Clark, 1954; Choquette, 1959, p. 236; O'Brien, 1960, p. 426). The proponents of a west-to-east development show in their interpretations an east-to-west development of some imbricate thrust zones within a thrust block.

In summary, field evidence in this region indicates that the older structures are truncated by younger ones in an east-to-west direction. 'This is a normal sequence of events for a single generation of movement and thrust development as a result of gravity. Gravitational movement, from an uplifted area to the west, generated lateral compressive stresses through the supracrustal rocks toward the east. During the movement, the stress was probably exerted uniformly throughout the mass by a discrete block. Furthermore, this block moved across the small Mesozoic basin up to the craton, where it was too thin to transfer stresses, encountered considerable friction, and broke into major slip surfaces. These surfaces are assumed to connect with the décollement zone. Some small discrete discontinuous faults occurred within the fault blocks.

Successive generations of movement, like those in the Idaho-Wyoming thrust belt, have produced a similar pattern of imbricate structures but with each new front east of the older faults. The disturbed belt in northwestern Montana represents the last generation of thrust development.

\section{STRATIGRAPHIC CONTROL}

The sedimentary rocks in the Sun River Canyon area consist of an alternating sequence of mudstone, limestone, sandstone, and a few interspersed igneous sills. The rocks appear to have reacted differently under various stress conditions. The reaction of a lithologic unit to stress seems to be partly determined by lithostatic pressure (depth of overburden) and partly by the properties of the units above and below. The ability of rocks to flex or flow and the mode of fracturing and shearing are directly related to the relative strength or weakness of a rock. The zones where fractures formed and thrust faults developed lie mostly in a particular group of mudstones and mostly within the cores of overturned or asymmetrical anticlines. The fractures extended across different rocks to the east of those anticlines.

\section{BEHAVIOR OF UNITS}

The sedimentary sequence varies in lithology, and its behavior differs under different stress environments. The depth of burial of the rocks (confining pressure) may have been important in controlling deformation. De Sitter (1956, p. 76) believed that "It raises the elasticity limit, changes some rigid rocks into ductile rocks, and thus influences the competency relation of the different rock types" The different structural patterns reflected in the Precambrian, Paleozoic, and Mesozoic rocks (Mudge, 1972, pl. 1) are probably related to gross lithologies (relative strengths of groups of rocks) and to the confining pressure at the time of deformation.

The Precambrian strata, about 7,300 feet thick, form relatively broad internally little disturbed fault blocks, which must have moved as coherent blocks. Locally, a few folds and small thrusts formed later than the relatively low angle initial thrusts. These strata include mudstones, thin sandstones, and some carbonates; all of which are virtually unmetamorphosed.

Many factors may have controlled the spacing of the exceptionally large thrusts and the relative lack of deformation in the thrust blocks made of Precambrian rocks. Two thin relatively strong and rigid units in the Precambrian rocks are the Helena Dolomite (350-625 $\mathrm{ft}$ thick) and the Precambrian sills (as much as $600 \mathrm{ft}$ thick). These units may have transmitted the stresses and determined the nature of deformation, whereas the mudstones behaved more or less passively, as discussed by Billings (1942, p. 89) and by Charlesworth (1961, p. 264-265). 
More important than lithology of the rocks, however, may have been the depth at which the faults formed, the distance of travel, and the angle of the fault plane. Hume (1957, p. 407) suggested that the most satisfactory explanation for the lack of much deformation within a fault block is the load under which it moved. At least 11,000 feet of strata lay above the South Fork thrust fault at the time of fracturing, and possibly as much as 20,000 feet of strata if Cretaceous rocks extended that far west (pl. 5). The South Fork thrust is shown on plate 5 as the largest fault in Precambrian strata. The two westernmost thrust faults in subbelts VIII and IX may have had an overburden of as much as 25,000 feet of strata. At such depths, the fluid pressure may have been abnormally high (Rubey and Hubbert, 1959, p. 194). As indicated by Badgley (1965, p. 37, fig. 2-38), many mudstones and some carbonates will reach their ultimate strength at depths of as much as 15,000 teet. The overlying stronger Paleozoic sequence (about 4,000 ft thick) also may have contributed to the homogeneity of the mass as another rigid and strong unit. Gravity sliding may have been by shear flow as proposed by Kehle (1970); as the décollement zone had a slope of moderate dip, deep burial (as much as $25,000 \mathrm{ft}$ ), and low-viscosity strata such as siltites and argillites.

The Paleozoic sequence, about 4,000 feet thick, consists mostly of beds of carbonate rock with some mudstone in the lower part (pl. 5). The beds of carbonate rock are generally less than 3 feet thick and are relatively evenly bedded. The various types of folds noted in them are open, closed, and chevron. These are usually of the flexural-slip variety, in which the fold is formed primarily by slippage along bedding planes (Donath and Parker, 1964, p. 51; Price, 1965, p. 79). However, in some folded sequences, flowage of the mudstone has thinned the limbs and thickened the crest and troughs, forming flexural-flow folds. In such sequences, beds of associated carbonate rock interbedded with mudstone either slipped along bedding or were folded into drag folds. Examples are in strata of Cambrian and Lower Devonian rocks at Allan Mountain and in Cretaceous strata along Bench Mark Creek (fig. 24). The estimated amount of overburden above the fault planes cutting Paleozoic rocks ranges from 7,000 to 10,500 feet (pl. 5) ; most of these faults were active under a cover estimated to be about 7,500 feet.

The Mesozoic rocks, about 7,000 feet thick, consist mainly of weak mudstone and partly of thin beds of sandstone (pl. 5). The maximum overburden above these rocks at the time of deformation was about 6,600 feet. The abundant closely spaced faults indicate that these rocks were brittle. Hume (1957, p. 409) believed that the amount of imbrication is directly related to the character of the beds in the fault slice above the sole fault; the stronger Paleozoic limestone provided a stiffening effect with fewer breaks than the overlying weaker Mesozoic rocks provided. Thrusts in the imbricate zones in Cretaceous strata along the Sun River very likely join at depth to form a single large thrust in Paleozoic strata. However, other thrusts in the Mesozoic rocks, not in imbricate zones, are probably relatively shallow and may not connect with a thrust. at depth.

Most folds in Lower Cretaceous rocks are associated with thrust faults. These flexural-flow folds probably reflect a fold in Mississippian strata below, which in turn is probably associated with a thrust (pl. 3).

Folds and faults in the Lower Cretaceous rocks in the western outcrop area are not as abundant or as closely spaced as those in the east. The Cretaceous rocks in the western Pretty Prairie fault complex comprise the Kootenai Formation, Flood Shale Member of the Blackleaf Formation, and a trachyandesite sill in the lower part of the Flood (pl. 4). The complex faulting and folding may have been partly controlled by the ability of the sill to transmit stress. The overlying and underlying mudstones are very weak compared with the strong homogeneous massive sill. The sill is bounded on both sides by relatively thick units of mudstone. These rocks were under an overburden of about 8,000 feet, whereas the same rocks in the east had a cover of only about 5,000 feet. How this sill, 500 feet thick, could be folded into a tight overturned fold without faulting is not understood. The depth of overburden at the time of folding may have been a factor. The abundant closely spaced longitudinal joints (tension) and shear fractures in the sill may have aided bending without offset by breaking (fig. 27). Flowage, if it occurred, is not evident. Slippage on bedding planes of the adjacent sandstone and mudstones may have assisted in bending the sill. The poorly exposed mudstone beds of the Kootenai did not flow in the crestal area of this anticline (section $A-A^{\prime}$, pl. 4) but did flow in the crestal areas of another fold (fig. 24) and in the Circle Creek anticline. The structures in these figures are of the same geologic setting and differ only in magnitude. As is evident in figure 29, shear fractures abound on the east limb, and movement on them may have thickened that limb.

The Pretty Prairie fault complex has many thrust faults and folded thrust plates (pls. 1, 4). The structures in the northwest overlie those in the southeast. The older fault plates beneath fault D (pl. 4) are exposed in a fenster south of the South Fork of the Sun River. In section $A-A^{\prime}$, fault $D$ truncates the older steeply inclined plates and was subsequently overridden by faults $F, G$, and $H$. Folding of plates D and F probably 


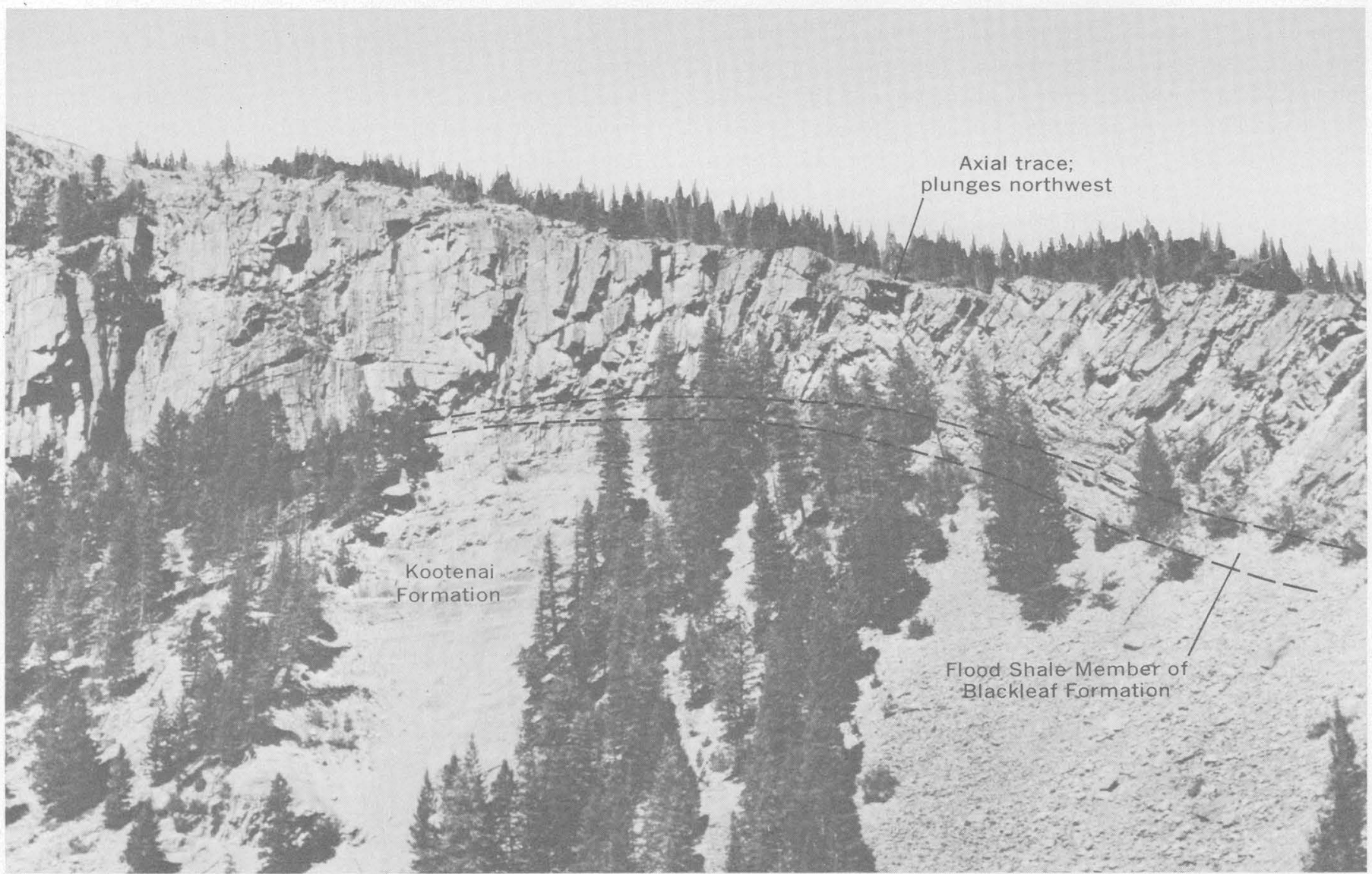

Figure 27. - The crestal area of a tight overturned fold capped by a trachyandesite sill (section A-A', pl. 4 ). Note the vertical jointing and the numerous low-angle fractures on both sides of the apex.

occurred during movement of thrust G. Fault plate H, however, was folded independently of others, possibly during its movement over plate $\mathrm{G}$ and against the more steeply inclined plates D and F.

South of the river, plate $\mathrm{D}$ was originally folded into a broad anticline (pl. 1; Mudge, 1972, pl. 1). During subsequent faulting, the upper plates were probably folded into the syncline, of which a remnant is shown in section $B-B^{\prime}$. During this period, the movement on fault $C$ may have been renewed to break plate $D$ near the crestal area of the anticline near and west of the syncline.

Farther south, fault Z, owing to a change in strike toward the southeast, truncated many older structures. This shortening of the section is readily apparent when sections $A-A^{\prime}$ and $B-B^{\prime}$ are compared with sections $C-C^{\prime}$ and $D-D^{\prime}$. The structural high of the complex appears to be in the area of sections $C-C^{\prime}$ and $D-D^{\prime}$. South of section $D-D^{\prime}$, the remaining structures plunge to the southeast or have been truncated by fault $\mathrm{Z}$.

The Pretty Prairie fault complex can be explained by one or a combination of the following hypotheses. (1) The varied lithology may have controlled the structures, because all the units involved do not occur elsewhere in the area-the mudstones do, but not with the sill (Mudge, 1972, pl. 1). (2) Possibly, the normal fault just east of the complex lowered the entire area more than 600 feet so that later thrusting into this structurally low area could have produced the pile. (3) A structural high in the subsurface to the south of the pile may have produced the northwest plunge of the pile and formed a barrier to the thrusts. This subsurface high may reflect a fold in basement rocks or, more likely, it may be an area where older thrust plates are piled on one another. As interpreted on plate 4, the closely spaced thrust faults tend to steepen abruptly.

Broad open folds are characteristically associated with the Upper Cretaceous rocks, especially in subbelt I. In the Sun River Canyon area, these folds are not associated with thrust faults. In the subsurface, however, some of the folds in the western part of the subbelt may be broken by small thrust faults that do not extend to the present surface.

An interpretation of the development of the structures in the Upper Cretaceous rocks along the North Fork of the Sun River is shown in the palinspastic 
sections on plate 4. During stage I, a sill intruded Lower Cretaceous rocks during the early phase of folding when the Circle Creek anticline and the Bridge Creek syncline were beginning to form (Mudge, 1972). These folds may have formed during the translation of the underlying low-angle thrust fault. More compression during stage II formed the North Fork syncline. The relaxing of compression late in stage III allowed the Elk fault to form. Later compression formed some new folds in the North. Fork syncline, as illustrated in stage IV. Thrust faulting again resumed during stage $\mathrm{V}$, and more small folds formed west of the syncline. Other thrust faults, formed from fractures in the small folds, produced the imbricate zone shown in stage VI.

\section{ZONES OR HORIZONS OF WEAKNESS}

Many individual zones or horizons of weakness in the sedimentary sequence were characteristic loci of fracturing and subsequent thrust faulting. These zones and a general classification of the faults and their relative abundance are shown on plate 5 .

The steplike effect of a fault is also illustrated on plate 5. A sole thrust may have developed in the Spokane Formation at the west and stepped progressively higher in the section into Cambrian, Devonian, and Mississippian rocks toward the east. Within the upper 6,000 feet of the section, most thrusts probably dissipated into smaller thrusts in the more brittle Mesozoic rock. Progressive upward stepping of faults through the stratigraphic section was noted in Alberta by Charlesworth (1961, p. 265) who stated that "the basal zone of décollement migrates from the lowest [unit] in the southwest to the highest in the northeast."

The main zones of décollement, as postulated on plate 5 are in the Precambrian, Cambrian, and Devonian rocks. With movement along thesesole thrusts, other structures evolved. The zones of weakness are chiefly in mudstones between carbonate or sandstone sequences. The lowest, initial zone of décollement, in and near the southern part of the area, is in a siltstone of the Spokane Formation. Toward the north, later thrusts peeled from the initial thrust and cut up-section into beds of clay shale and claystone in the lower part of the Shepard Formation. In the central Sawtooth Range (subbelt III), the main zone of décollement exposed is at the top of a mudstone and at the base of the upper, massive limestone of the Pagoda Limestone (pl. 5). Other weak zones in the Cambrian are in the Steamboat Limestone and at the base of the Devils Glen Dolomite. In the Devonian rocks, the thrusts are restricted mostly to an evaporite solution breccia in the lower part of the lower member of the Jefferson Formation. A similar weak zone is also at the base of a thick evaporite solution breccia in the Three Forks Formation.

The most common fault surface in Mississippian rocks is at or near the contact between the lower and middle members of the Allan Mountain Limestone (pl. 5). The lower member consists of very thin platy beds of limestone with some calcareous mudstone, whereas the overlying middle member has thick beds of chert-bearing limestone. Along strike, many of the faults migrate upward through the middle member to the base of a massive limestone in the upper member.

The Rierdon Formation is the most common locus of thrusts, especially back-limb thrusts, in the Jurassic strata. The dark-gray calcareous mudstones in the formation were easily deformed and faulted.

Many horizons were loci of small thrust faults in the Cretaceous rocks, but two horizons, in particular, are widespread (pl. 5). These are in mudstone of the Kootenai Formation and are most widespread in the overlying Flood Shale Member of the Blackleaf Formation. The Flood Shale Member has also been highly deformed in many places by intraformational folds and small tear faults. It is one of the few thinly laminated clay shales in the entire stratigraphic section. Apparently, this very weak unit offered virtually no resistance to stress. Beds of bentonitic shale and bentonite in the Cretaceous rocks were also loci of faults.

\section{DEPTH OF THRUSTING}

Evidence from mapping and well logs along the eastern margin of the disturbed belt shows that the stratigraphic positions of the basal thrust faults vary markedly from west to east. All data suggest that the lowest stratigraphic position and greatest depth of the zone of décollement are to the west. Generally, the décollement steps up progressively in stratigraphic position and elevation to the east.

The oldest strata are Precambrian Belt rocks that crop out only in the westernmost fault blocks (subbelts VII, VIII, and IX). In many places, Paleozoic rocks, up to and including Mississippian strata, overlie the Belt rocks (Deiss, 1943a; McGill and Sommers, 1967; Johns, 1964; Sommers, 1966). Mesozoic rocks are not preserved above these strata, and it is doubtful that they existed in any appreciable thickness at the original sites of these fault blocks. In the western Lewis and Clark Range and the eastern Swan Range, the total thickness of strata is as much as 25,000 feet ( Walcott, 1906; Johns, 1964). The décollement zone in the Belt rocks, just west of the Sun River Canyon area, is interpreted to be at a depth of about 20,000 feet. The Belt strata are 6,000 feet thicker to the west (from 7,300 $\mathrm{ft}$ in the east to about $13,300 \mathrm{ft}$ near the South Fork of the Flathead River). A minimum of 11,000 feet of 
strata overlay the fractures from which the South Fork thrust décollement (subbelt VII) formed. If Cretaceous rocks extended over this area, the depth was much greater.

In the Sawtooth Range, the oldest strata exposed in the thrust blocks are Cambrian (subbelts III, IV, and V). The complete section of Jurassic and Cretaceous strata found to the east very likely extended over the source area before the orogeny. Rocks as young as the upper part of the Two Medicine Formation crop out in the western part of the Sawtooth Range (Mudge, 1972, pl. 1), and younger Upper Cretaceous rocks were also probably present. The sedimentary sequence above the Cambrian décollement is thus assumed to have been at least 10,500 feet thick (pl. 5), if no higher thrust plates were superposed at the time of the décollement.

East of the Sawtooth Range, in subbelt II, the apparent décollement ranges in position from the lower part of the Devonian to the lower part of the Mississippian. Farther east, it stepped up into Cretaceous strata (Weimer, 1955, p. 148).

The logs of a few scattered oil wells along the east margin of the disturbed belt indicate that most did not penetrate a décollement. Four well logs are given as examples. In Gulf Oil-Shell Oil Tribal 1, east of Glacier National Park in the SE $1 / 4 \mathrm{NW}_{4} / 4$ sec. 23, T. 36 N., R. 15 W., Glacier County (Am. Strat. log M815), 23 thrust faults that repeat Cretaceous rock were recorded. The lowest is at 12,760 feet; it is overlain by Mississippian rock. The hole bottomed at a depth of 13,150 feet in Mississippian rock. In General Petroleum Blackleaf 1 , in the $\mathrm{SE} 1 / 4 \mathrm{NW}_{14}$ sec. 14 , T. $26 \mathrm{~N}$., R. 9 W., west of Pendroy, Teton County (Am. Strat. $\log 135$ ), at least four large thrusts that repeat Devonian and Mississippian rocks were recorded to a depth of 7,075 feet. Whether other thrusts lie below is unknown. About 4 miles northeast of that well, Gulf Oil and Stanolind Oil Teton-Knowlton 1, in the SE 14 NW 14 sec. 8 , T. 26 N., R. 8 W., Teton County (Schlumberger electric $\log$ ), was drilled to a depth of 7,800 feet. The log shows thrust faults that repeat Cretaceous strata to a depth of 3,600 feet, below which a normal sequence was penetrated to the bottom of the hole in the lower part of the Devonian. Southeast of the Sun River Canyon area, a well drilled by Pan American and Gulf Oil (Gelsinger 1), in the SW $1 / 4 \mathrm{SW}_{14}^{1 / 4}$ sec. 32, T. 20 N., R. 7 W., Lewis and Clark County (Am. Strat. $\log$ M471), cut thrust faults that repeat the Upper Cretaceous strata to a depth of 5,130 feet. Below this depth, the log shows a normal section down to and including the upper beds of the Mississippian, at 9,327 feet.

\section{FOLDING AND INITIAL THRUST FAULTING}

Field evidence shows that some thrusts apparently formed from fractures that developed along the axis or on the east limb of asymmetrical or overturned anticlines. Other thrusts, however, probably formed independently of a fold. West of the initial thrust, subsequent faults commonly formed imbricate zones higher on the east limb and locally in the crestal area of the anticlines. Back-limb thrusts were formed on the back (west) limb of the anticlines, mostly by the same. stresses that formed the other faults within a fault block. Some thrust plates were folded during thrusting; others were folded after.

The evidence that some folds formed prior to thrusting and that thrust faults originated from fractures in the east limb or axis of the anticlines is as follows: (1) Symmetrical folds not associated with thrusts are in the eastern part of the area; (2) a few thrusts were traced to the axis, and some were traced to the east limb of asymmetrical or overturned anticlines; (3) the incompetent beds in some folds associated with thrusts were not thickened or thinned, and drag folds were not developed adjacent to the fault or in the crestal or trough areas of the folds; and (4), less conclusively, the very large size of some folds in itself suggests that they were too large to be formed by frictional drag.

Many thrusts in the Sawtooth Range are flexuralslip thrust faults, in the classification proposed for similar faults in Alberta by Price (1965, p. 79). He noted that such faults are kinematically related to flexural-slip folds, and that they occur in the limbs of folds, that they almost parallel the fold axes, and that they dip in the direction of bedding. Also, their direction and sense of displacement agree with those of interstratal slip. Most faults cut bedding at relatively low angles deep within the fold, and they arise within a fold limb where the amount of movement increases in the direction of an anticlinal axis.

The large thrust faults in subbelt IIIa are very similar and probably developed from a sole thrust, as shown in stages II and III in figure 28. Except for the Home thrust block, each block in subbelt IIIa contains identical strata (Mudge, 1972, pl. 1). The dip of the faults, in general, increases progressively westward in the western faults of subbelt IIIa.

The large faults in subbelt IIIb are similar and may be related to a single sole fault in the Sun River Canyon area. The eastern two thrust blocks (the Palmer and Allan thrusts) contain, in their lower parts, Cambrian strata not present in subbelt IIIa. If the Palmer thrust is the sole thrust, the Allan thrust and associated fold developed later (thrust 2, fig. 28) and moved farther and with greater stratigraphic throw than the sole 

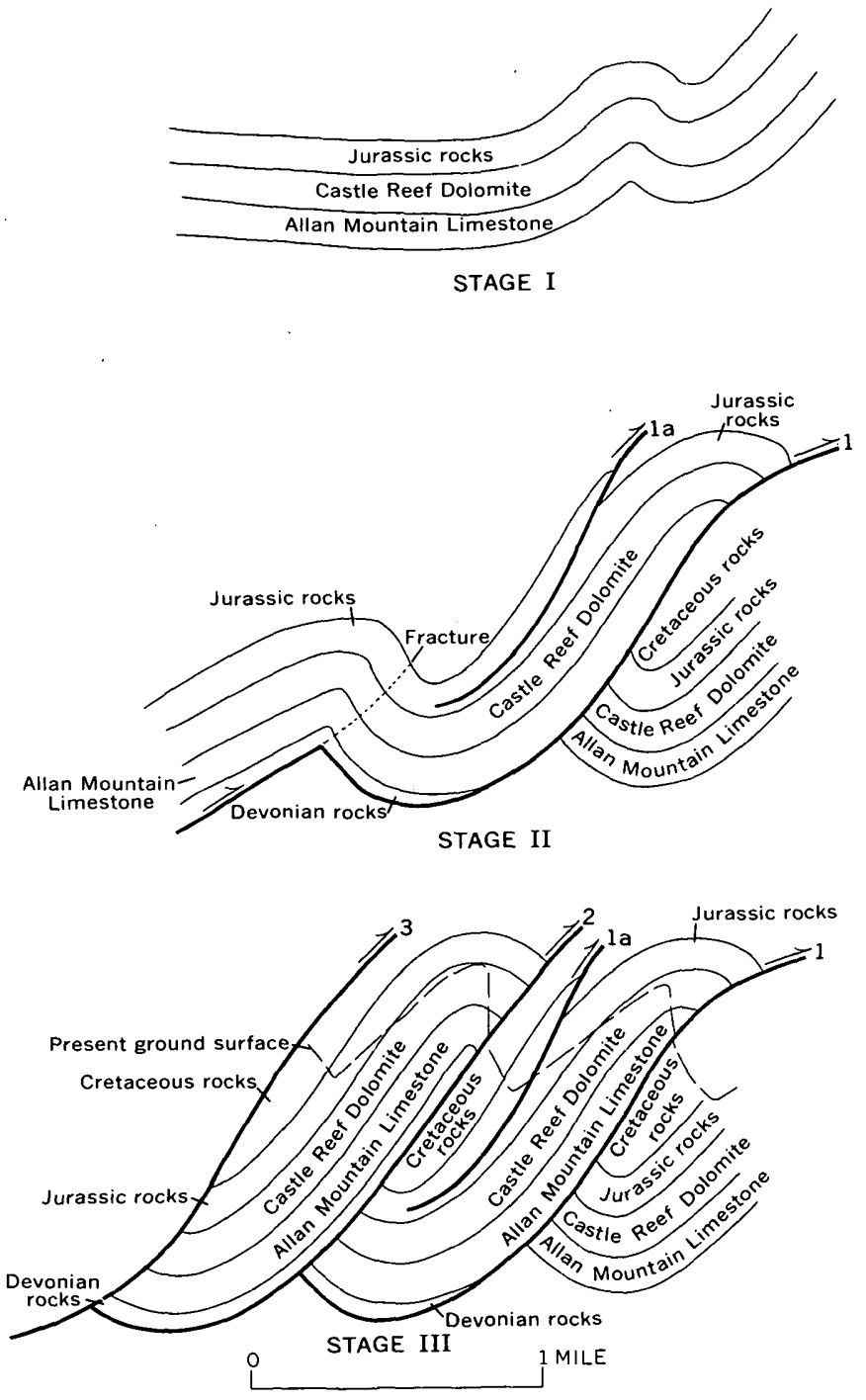

Figure 28.-Diagrammatic sections showing hypothetical development of most thrust faults in the Sun River Canyon area. 1, initial thrust; 2 and 3 , younger large thrusts; and 1a, back-limb thrust.

thrust. A similar relationship was illustrated by Hume (1957, p. 400) in the Jumping Pound structure in Alberta. There, a second fault broke the east limb of the anticline above the sole thrust. An alternate interpretation of figure 28 is that the younger anticline on the west limb was originally a large broad asymmetrical fold whose basal thrust (thrust 2) displaced the Cambrian rocks vertically more than fault 1 . In this sequence, fault 3 is represented by the Dry thrust.

Evidence is meager as to the origin of the large thrust faults along which the Precambrian rocks of subbelts VII, VIII, and IX moved eastward. These low-angle thrusts moved many miles parallel to the bedding, or nearly so, and may have formed without appreciable folding, as suggested by Douglas (1950, p. 83). His hypothesis is supported by the general lack of a preexisting fold in the upper plate. However, possibly these thrusts broke along fractures in a fold under a thick cover. Erosion may have removed a former fold from the overriding block. For example, the front of the South Fork thrust plate once lay at least 4 miles east of its present eroded edge.

Exposures along the West Fork of the Sun River suggest that an overturned fold probably existed before the South Fork thrust zone formed. As shown on the map in figure 29, the thrust rests on overturned Mississippian and Jurassic rocks. In many places, both to the north and to the south, highly deformed Mississippian rocks lie beneath a plate of Precambrian rocks (Childers, 1963, pl. 1; Schmidt, 1963). The younger rocks below are probably remnants of the stratigraphically higher part of the overturned limb of the fold from which the South Fork thrust zone originated. The possible development of this fold and subsequent thrust faults is shown in figure 29. The primary beddingplane thrust (fig. 29, stage III) originated deep in the fold, as shown in stage I, and along a bedding plane.

The Allan fault block in subbelt IIIb closely resembles a fault block in central Turner Valley, Alberta, illustrated by Gallup (1951, p. 806) and Hume (1957, p. 398). Both show large overturned anticlines from which an initial thrust fault broke across the east limb, and subsequent thrust faults formed an imbricate zone on the west limb. The anticline in Turner Valley formed prior to the early Tertiary deformation, possibly during early Mesozoic time (Gallup, 1951, p. 817 ; Hume, 1944, p. 42; Hume 1957, p. 398; Link, 1953, p. 132). The anticline in the ridge containing Allan Mountain is considered early Tertiary in age.

An initial or sole thrust, generated along a weak set of beds, may have developed independently of a fold (pl. 5). A hypothesis of Douglas (1950, p. 83-84), further discussed by Hume (1957, p. 408), explains the formation of a thrust from a fracture without appreciable folding and postulates that the movement of a thrust over resistant and less resistant strata forms back-limb thrusts and folded fault plates. Except for the origin of some of the initial thrusts, Douglas' hypothesis is applicable to structures in the Sun River Canyon area.

The distance of travel of the overriding block on the initial fault may be controlled by many factors. The fluid pressure under a thick overburden, as discussed by Rubey and Hubbert (1959, p. 185-202), may be essential, especially for the large thrusts. However, Kehle (1970) believed that gravity sliding. may be accomplished by the deformation (simple shear flow) of the lowest viscosity strata in a décollement zone. The amount and duration of stress exerted on the block is 
undoubtedly another factor; as is the resistance encountered during movement. The frictional resistance is determined by the composition of the underlying beds, by the composition of the beds being transected, or by a steepening of the fault surface in a rotated fault block.

The faults appear to have the configuration of a "lazy S" or an integral sign (pls. 3, 4). The faults dip west at low angles in the topographically high areas, with local reverse dips to the east. In topographically low areas, the faults dip steeply to the west. At greater depths, the dip of the faults is very likely more gently to the west. Most faults dip $30^{\circ}-70^{\circ} \mathrm{W}$. At Castle Reef, the Sawtooth thrust dips as much as $10^{\circ} \mathrm{E}$. near the crest of the mountain but reverses and dips westward at gradually increasing angles at progressively lower elevations. At Sun River, 3,500 feet lower, the dip is about $65^{\circ} \mathrm{W}$. This steepening with depth has been illustrated by many authors, including Deiss (1943b, p. 1148), Weimer (1955, p. 146), and me (Mudge, 1965a, 1966a, 1967, 1968). A steepened fault surface may have been caused by a buttress to the east created by a piling up of thrust plates or by the west limb of the next anticline or fault block. Such steepening clearly increased the tangential resistance to the compression as the fault block rotated.

The younger faults of an imbricate zone formed in succession westward from the initial thrust; they probably formed when the initial thrust encountered a barrier. These thrusts also started along fractures and peeled upward more steeply than the initial thrust.

Most exposed thrust faults in the Sun River Canyon area are strike thrusts, although at depth they may turn into bedding thrusts. Most faults dip more steeply than the overlying strata, and some dip more gently than the underlying strata. This relation holds true in Cretaceous rocks east of the mountain front, as well as in Paleozoic rocks within the mountains. It is also evident on the highest ridge and in the deepest canyon, a relief of 4,000 feet. Thus, a fault cuts younger rocks at higher elevations. The Diversion thrust at the Sun River dips $45^{\circ} \mathrm{W}$; t the overlying strata dip $25^{\circ} \mathrm{W}$. Farther north, the fault dips west $5^{\circ}-10^{\circ}$ more steeply than the overlying strata; locally the difference in dip is as much as $45^{\circ}$. Dips of the Sawtooth thrust at Castle Reef vary considerably along the strike; generally the fault dips as much as $30^{\circ}$ more steeply than the strata. In the Sun River Canyon, the French thrust dips $67^{\circ} \mathrm{W}$., the strata above dip $50^{\circ} \mathrm{W}$., and those below $\operatorname{dip} 70^{\circ} \mathrm{W}$. There, a shear curves upward to a vertical position above the fault. On Allan Mountain, a thrust dips $55^{\circ} \mathrm{W}$.; the overlying strata, $50^{\circ} \mathrm{W}$. There, a shear also curves upward from the fault to an angle of $90^{\circ}$. Near the Sun River east of the moun- tains, the Taft Hill Member of the Blackleaf Formation is the lowest unit in many fault blocks, whereas at a higher elevation to the north, the Vaughn Member is the lowest unit. Many other examples of these discordant relations can be seen in the Sun River Canyon area.

Fractures cut the carbonate rocks at greater angles than they cut nearby mudstones or other less competent rocks. Thrusts that cut alternating competent and incompetent zones thus produce a steplike fracture pattern, as has been noted in Alberta, Canada (Rich, 1934; Douglas, 1950 , p. 90 ; Hume, 1957, p. 397). In the Sun River Canyon area the fault patterns are similar.

Bedding thrusts are less common in the Sun River Canyon area than strike-thrust faults. As previously stated, most strike thrusts on the surface may turn into bedding thrusts in the subsurface. Bedding thrusts have been recorded in many places in northern Montana and Alberta (Deiss, 1943a, p. 249; Beach, 1943, p. 51; Douglas, 1950, p. 90; Hume, 1957, p. 397; Charlesworth, 1961 , p. 265; Childers, 1963 , p. 161). Locally, some bedding thrusts - for example, the western imbricate of the Norwegian thrust (pl. 1)-are imbricates of large thrust faults. Other large thrusts that locally follow bedding are the Sawtooth, French, and Diversion thrusts (Mudge, 1972, pl. 1).

\section{BACK-LIMB THRUST FAULTS}

Back-limb thrusts are common in most large fault blocks, and most of them form imbricate zones. The back-limb thrusts developed on the west limb of anticlines as anticlines underlay the fault. Some thrusts on a west-dipping fault plate may also be back-limb thrusts, but data are lacking to prove it. Most backlimb thrusts have moved relatively little and do not connect with a sole thrust. Other faults of somewhat greater travel usually connect with sole thrusts.

Back-limb thrust faults, which have been described in many localities in Alberta and northwestern Montana, have the following characteristics:

1. They are concave toward the original pressure (Douglas, 1950 , p. 91 ; Irish, 1965 , p. 104).

2. Their blocks rotated along an upward-steepening fault (Douglas, 1950, p. 91; Irish, 1965, p. 104). Where back-limb thrusts form an imbricate zone in a large fault block, the faults become progressively steeper westward and are generally closely spaced; and, as Douglas (1950, p. 94) noted, each thrust repeats the strata of the back limb of the anticline, thus widening the structurally high area.

3. They lie at small angles with the bedding (Irish, 1965, p. 104).

The back-limb thrusts in the Sun River Canyon area demonstrate all these features (pl. 4). 


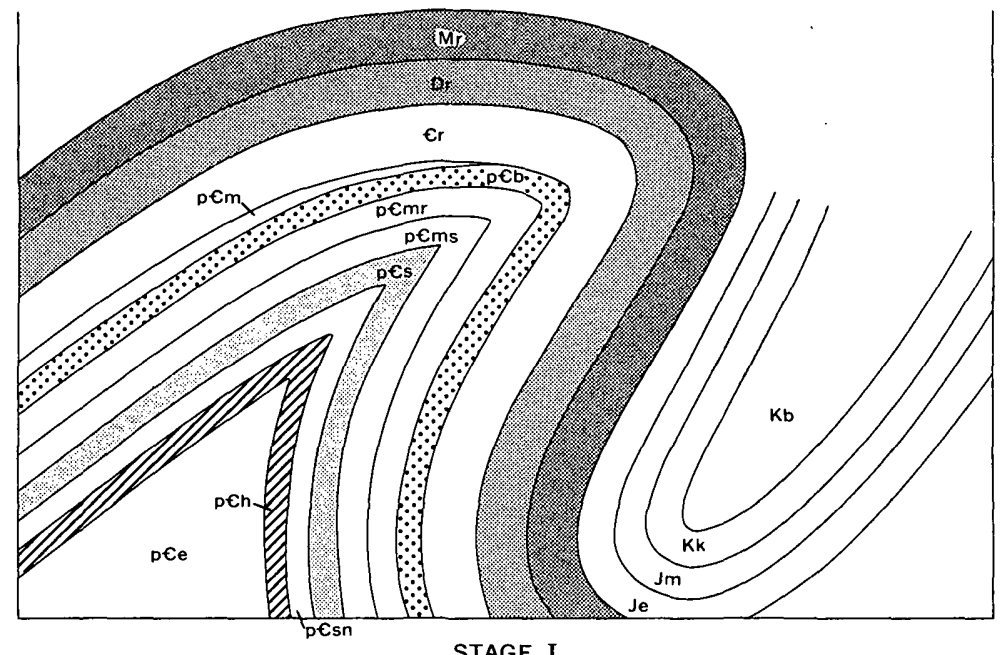

EXPLANATION
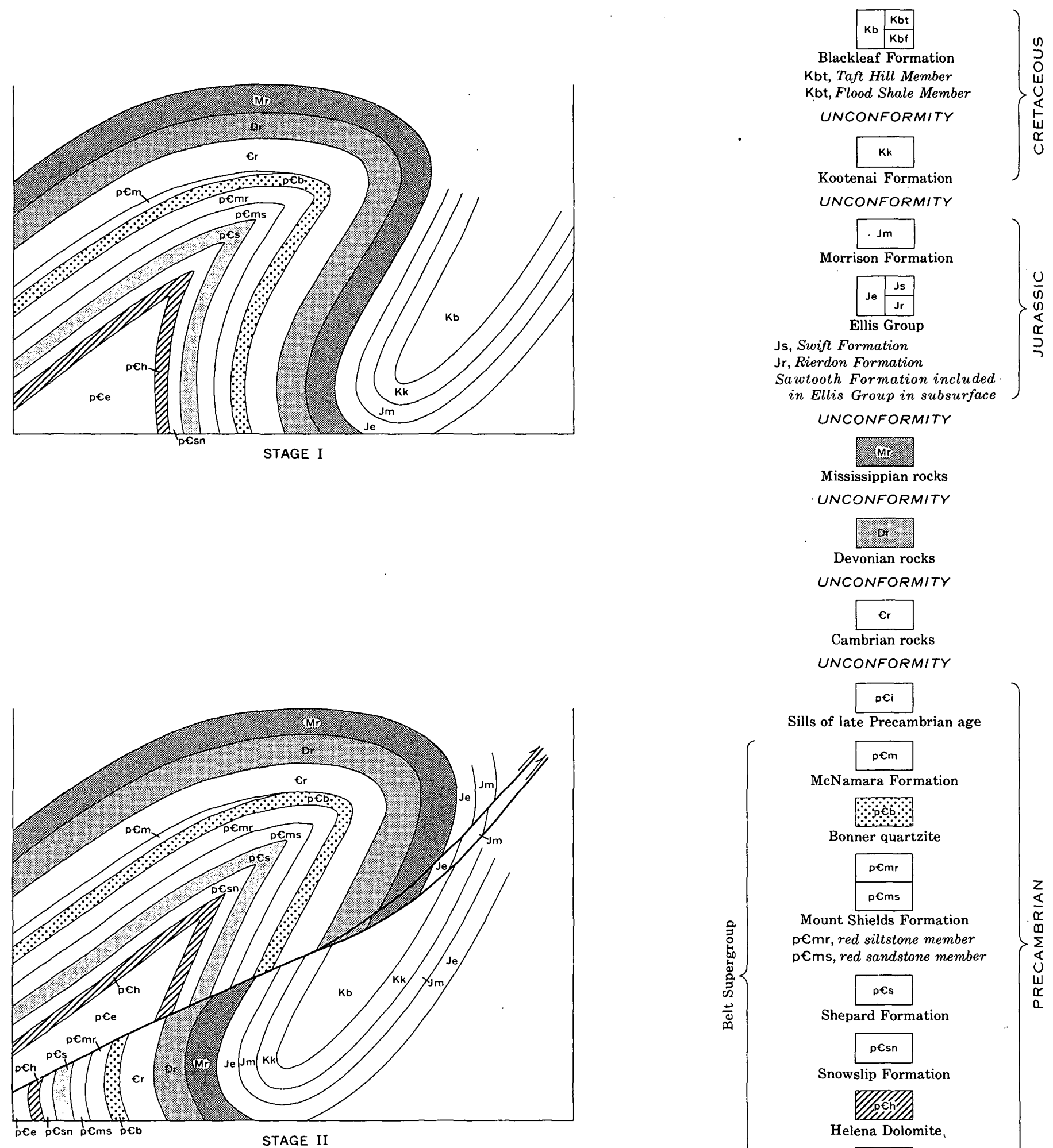

Sills of late Precambrian age

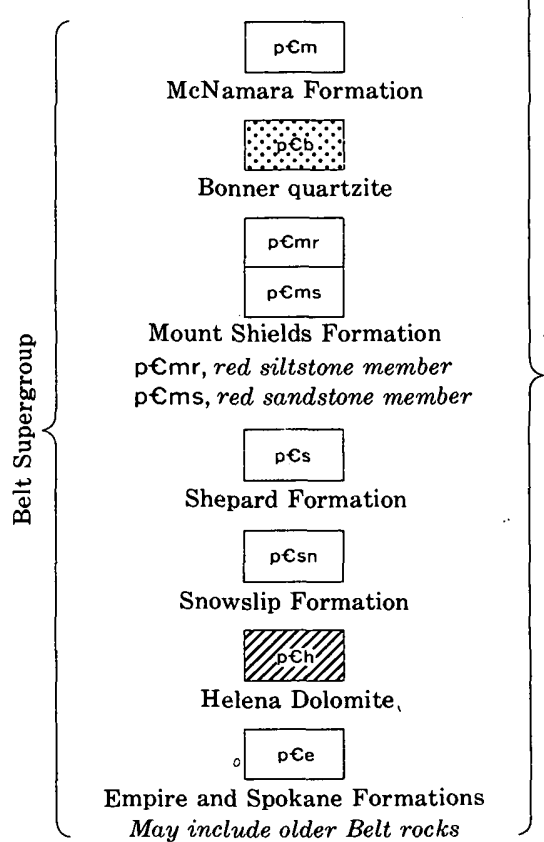

FIGURE 29.-An interpretation of the development of the South Fork thrust zone and associated structures. Stage I, development of initial thrust. Stage III, formation of South Fork thrust zone from additional fractures 


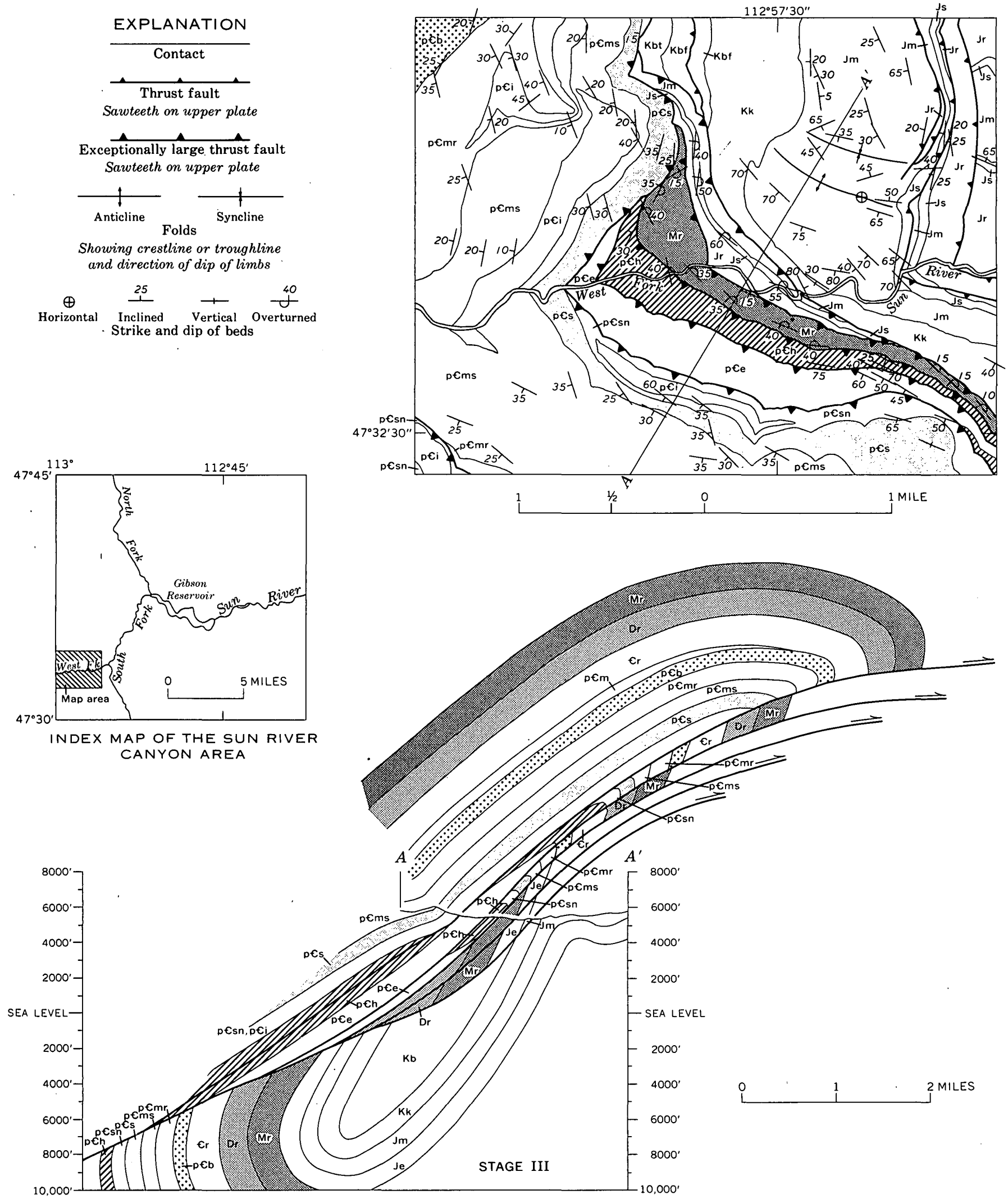

overturned fold. Stage II, initial thrust formed from fracture in overturned limb; a small subsequent thrust developed above the higher in the overturned limb; distance of translation is about 4 miles. 
Good examples of back-limb thrusts are exposed in every valley in the Sawtooth Range. Many small backlimb thrusts, mostly in weak mudstone of the Rierdon and Kootenai Formations, repeat parts of these strata (Mudge, 1972, pl. 1). Similar faults are exposed on the west side of the overturned anticline along the Allan Mountain-Arsenic Peak ridge (pl. 4). Fault IV on plate 4 is the easternmost of this group and becomes the main thrust to the south. To the north, fault IV is folded with the others, and a higher back-limb thrust developed to the west.

Back-limb thrusts may have been produced by various stress conditions. Douglas (1950, p. 89) and Irish (1965, p. 104) explained them as resulting from greater differential movement between strata on the west limb of an anticline than on the east limb. Douglas (1950, p. 90) suggested that a cumulative stress was exerted differentially on the weaker strata during folding. A hypothesis by Douglas (1950, p. 90, fig. 24) postulates that the back-limb thrust was the first formed and that imbrications formed in front of it, possibly even in the next syncline to the east. Additional fault slices may or may not merge with the initial thrust (Irish, 1965, p. 104). Another hypothesis, by Hume (1957, p. 409), postulates that the initial fault changed from a steep to a less steep angle and created a fold. Hume believed that such a fold tended to anchor the thrust, so that another fault developed from the sole thrust on the west limb of the fold. (See fig. 30.)
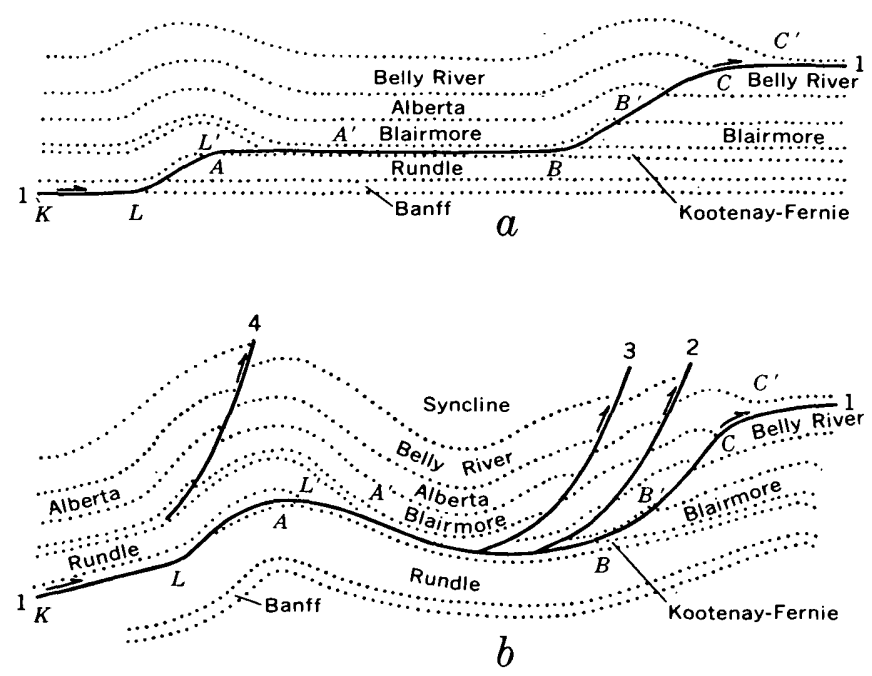

Figure 30.-Diagrams illustrating stages in the formation of folded faults (1-1) and back-limb thrust faults $(2,3,4)$ above the initial thrust (Hume, 1957, fig. 9). Illustration reproduced through the courtesy of the Geological Society of America. $a$, Initial stage, showing relation of fault habit to stratigraphy. $b$, Later stage, showing folding of fault plane and strata above and below fault (shown by italic capital letters).
This hypothesis explains some of the back-limb thrust faults in the Sun River Canyon area.

Another hypothesis may be applicable where the thrust-fault blocks are closely spaced and steeply dip. ping (fig. 28). A typical fault block contains strong Mississippian carbonates in the lower part overlain by weak Jurassic and Lower Cretaceous clastic rocks. While the anticline and the initial thrust were forming, the force was transmitted mainly through the stronger carbonate unit; the weaker mudstone behaved passively. Differential stress was exerted on the weak and strong rocks when the fault block rotated; the block moved at a steeper angle where resistance was greater, and small faults formed in the weaker beds. Back-limb thrusts that may have formed in this manner are those in the Rierdon and Morrison Formations, particularly in subbelt III. Possibly, however, these faults formed during folding before large thrusts formed, as illustrated in figure 28. Differential stress exerted on the weak Jurassic mudstones during compression may have formed the back-limb thrusts. The back-limb thrusts would then be repeated by the large thrusts, as in subbelt III. But the inconsistent patterns of the back-limb thrusts in various blocks indicate that they formed independently and subsequent to each large thrust.

Another explanation, however, is required for the thrusts in Lower Cretaceous rocks stratigraphically higher than those previously discussed. These thrusts occur beneath the next westerly large thrust faults (Mudge, 1972, pl. 1) and probably formed at the same time as the overlying thrust (fig. 28). As mentioned (p. 16-17), small recumbent anticlines and synclines are locally present in Lower Cretaceous rocks in subbelt III. In each, a thrust fault formed along the axial plane in the northern extent of each anticline.

\section{ORIGIN OF IMBRICATE ZONES IN GRETACEOUS ROCKS}

The closely spaced thrust faults comprising imbricate zones in subbelt II appear to have formed in a way different from the others. The Mesozoic mudstones and sandstones are weaker than the underlying Paleozoic carbonates and therefore reacted differently to the same stress.

These Mesozoic rocks, under a load of less than 6,000 feet of strata, were probably ductile in the lower part and brittle in the upper part. The brittleness of the Mesozoic rocks is suggested by the close spacing of the thrust faults, especially those in the Neal and Stecker imbricate zones (pl. 1). These rocks were folded into asymmetrical or overturned anticlines by stresses from the west. The mechanics that formed these zones probably followed a pattern like the following: The primary thrust fault formed along fractures in the Paleozoic carbonate rock which projected at an angle of about 
$45^{\circ}$ through the east flank of the anticline into the overlying Mesozoic rocks. With additional stress on the underlying carbonate rocks and with the least stress vertically, the block very likely rotated to form a buttress, and a second fault formed in the overlying rocks. This fault formed at a steeper angle and west of the previous fault. As the underlying carbonate block continued to move upward and to rotate, additional faults formed in succession westward in the overlying weaker rocks and at a steeper angle, leading finally to a fan-shaped imbricate zone. In both the Neal and Stecker imbricate zones, the last thrust to form had a more southeasterly strike, and it truncated some of the earlier thrusts to the south.

\section{FOLDED THRUST FAULTS}

Folded thrust faults are relatively common in the disturbed belts of Montana and Alberta. A review of folded thrust faults in the Foothills area of Alberta, Canada, was presented by Scott (1951, p. 2317). In the Sun River Canyon area, one or more fault plates have been folded in all subbelts except subbelt $\mathrm{I}$.

Folded faults in this area are of two types-those that formed during the thrusting and those that formed afterward. A combination of the two types is locally present where thrust plates are piled up. Both types, with slight modification, occur in Nevada, as described by Gilluly (1960, p. 79) and Gilluly and Gates (1965, p. 109); and one type or the other in Alberta, Canada, has been described by Hume (1941, 1957), Hage (1942, p. 75), Douglas (1950), Scott (1951), and Price (1962).

\section{FOLDING DURING THRUSTING}

Folding during the thrust movement has locally taken place in a sequence of alternating competent and incompetent strata. Folding began where a thrust fault deviated in inclination because of change in competence of the strata truncated. Many folded plates, like those in Alberta (Douglas, 1950, p. 84 ; Hume, 1957, p. 407), developed into an anticline where the dip of the fault changed upward from a steep dip to a less steep dip and into a syncline where the dip changed upward from a less steep dip to a steeper dip (fig. 30).

In the Allan thrust zone in upper Cabin Creek (pl. 1), some of the upper plates have been folded into the Beartop anticline and Biggs Creek syncline. From sections $A-A^{\prime}$ and $B-B^{\prime}$ on plate 4 , it is evident that the lower thrust faults (faults Ia and IIb) also very likely formed prior to that folding. Folding may have begun when fault IV truncated the underlying Mississippian and Cambrian carbonate units. A change in the dip of the fault may have created the fold, as shown in figure 30 and as postulated by Douglas (1950, p. 93) and Hume
(1957 p. 408). Fault IV, shown on plate 4, very likely formed during folding, because the fault cuts up-section east of the crest of the fold. Additional stress accentuated the folds to their present amplitudes, and backlimb thrust faults to the west formed independently of the sole thrust.

The thrust plates in the upper part of Cabin and Grouse Creeks dip more steeply than those,farther south. The variation in dip is illustrated by comparing cross sections $A-A^{\prime}$ and $B-B^{\prime}$ with $C-C^{\prime}, D-D^{\prime}$, and $E-E^{\prime}$ on the Arsenic Peak quadrangle map (Mudge, 1967). The steeper dips may be related to the buttressing by the wide zone of imbricate thrust blocks to the east. Farther south, where this imbricate zone is absent and the Allan thrust zone contains fewer faults, the dip of the combined Allan thrust plate is lower. The change in dip, therefore, may have strongly influenced the creation of additional thrust faults in the overturned limb as well as the folding of the thrust plates.

The Pretty Prairie fault complex contains both types of folded -thrust plates (pl. 4; Mudge, 1972, pl. 1). In section $A-A^{\prime}$ of plate 4 , fault $\mathrm{D}$ truncates nearly vertical strata in older fault blocks. Folding of plates $\mathrm{D}$ and $\mathrm{F}$ occurred later than the fault movements but prior to or during movement on fault G. Fault G truncated fault blocks $\mathrm{D}$ and $\mathrm{F}$ and deviated to a lower dip in the weaker strata, and a fold developed. As inferred in cross section $B-B^{\prime}$, the fold projects downward through older fault blocks. During the movement of a low-angle thrust, steeply dipping plates formed a barrier. To the east, additional movements against this barrier probably created the overturned fold in fault plate $\mathrm{H}$. Thus; in this pile of thrust plates, some plates were folded during thrusting, others were folded essentially contemporaneous with but after thrusting, and others were folded after the thrusting had stopped.

Figure 24 illustrates another example of folding that began during thrusting and continued after thrusting. The sandstone bed shown was folded into a small syncline prior to or during an early stage of thrusting, judging from the amplitude of the syncline as compared with that of the anticline. The anticline was probably formed where the thrust flattened and truncated the sandstone bed to the east. The anticline is reflected through both plates, but the syncline is not. If the syncline formed after thrusting, the mudstone above the fault would have flowed into the trough. The thin bed of limestone in the mudstone, above the fault and below the sill, remained parallel with the sill across the synclinal trough. However, drag folds were formed in these beds of limestone in the anticline. The axes of some of the drag folds parallel the axis of the anticline. 


\section{FOLDING AFTER THRUSTING}

Folding of a thrust plate after thrusting is common both in northwestern Montana and in Alberta. In northwestern Montana, Deiss (1943b, p. 1158-1159) described subparallel low-angle thrust plates which were later folded. He (1943b, fig. 5) showed incompetent Mesozoic rocks, above a thrust and below two parallel thrusts, in a drag fold that formed a broad anticline in the overlying plates. In Alberta, examples of thrust plates folded after faulting were cited by Hume (1941, p. 90, 92; 1957, p. 408), Hage (1942, p. 75), Scott (1951, p. 2327, 2336), and Price (1962, p. 348-349).

The best example of folding after thrust faulting is illustrated in the banks of Freezeout Creek (fig. 22), where a low-angle thrust, almost a bedding fault, repeated the lower two members of the Marias River Shale, which were later folded into two small monoclines present in both plates.

Another example of postthrust folding is in the $\mathrm{NE}_{14}^{1 / 4}$ NE $1 / 4$ sec. 18, T. 21 N., R. 8 W., where four low-angle thrust faults repeat the upper strata of the Taft Hill Member of the Blackleaf Formation (fig. 10). These strata and faults were later compressed into a tight syncline and anticline. The small fault shown in the upper righthand corner of figure 10 very likely formed when the syncline was tightly compressed and the mudstone flowed between bed $J$, above the fault, and the sandstone above bed J.

A few generalizations can be drawn from this and other studies of folded thrust plates. The following data are particularly applicable to the Sawtooth Range in the northern disturbed belt in Montana and to Foothills parts of that belt in Alberta:

1. Folded thrust plates are common.

2. They occur mainly in connection with alternating competent and incompetent strata.

3. They are common in areas of closely spaced structures.

4. Back-limb faults are associated with them. Backlimb faults formed as a result of folding and later than the main faulting (Hake and others, 1942, p. 317).

\section{ORIGIN OF FOLDED THRUST PLATES}

All the folding of thrust plates occurred either during or shortly after thrusting in the Sun River Canyon area. Regional folding of thrust plates after cessation of faulting has been attributed to some of the folded plates in Alberta by Scott (1951, p. 2346), but this is not applicable in this area.

Where folding was concurrent with thrusting, the change in the inclination of a fault appears to be directly related to the nature of the strata traversed by the fault (Douglas, 1950, p. 84; Hume, 1957, p. 407). In northwestern Montana and in Alberta, a change in dip of a thrust takes place where:

1. The fault rises stratigraphically across a different lithology in either plate.

2. A thrust abutted or overrode a pile of thrust plates.

3. A thrust abutted or overrode the limb of an anticline.

4. The strike of a fault changed.

Shearing, crumbling, and brecciation should be more severe where folding is concurrent with thrusting than where folding occurred after thrusting.

Folding of a thrust plate shortly after thrusting may be attributed to one or more of the following factors:

1. Folding subsequent to a thrust fault but before the next younger thrust was formed during the same orogeny.

2. Underthrusting in which the thrust moved in one of the various settings for folding during thrusting. Some underthrusting may be a renewed movement on an older thrust.

3. Differential uplift during a younger orogeny.

4. Flowage of weak strata in a lower plate caused by later stress, which creates a bulge reflected in overlying plates.

5. Folding produced by faulting or crumpling in lower fault slices as they moved forward under the load of an overlying mass (Hume, 1957, p. 407).

\section{AGE OF THE OROGENY}

Most workers think that the orogeny that formed the disturbed belt in northwestern Montana began no earlier than very Late Cretaceous and ended no later than late Eocene and probably took place chiefly during Paleocene to late Eocene time. Very little evidence for dating the orogeny has been found locally. Rocks as young as the St. Mary River Formation (Upper Cretaceous) were folded and faulted. East of Glacier National Park, near the Canadian border, Stebinger (1917, pl. 24) showed the Willow Creek Formation as folded and faulted. The Willow Creek is very Late Cretaceous and Paleocene in age (Tozer, 1053, p. 26). Bossort (1957, p. 51) believed that deformation began in southwestern Alberta in early Paleocene time. North and Henderson (1954) stated that the main deformation in Alberta was post-Paleocene, and many workers in Montana and in Alberta, Canada, believed that it ended before the Oligocene (Russell, 1951, p. 47; McMannis, 1965, p. 1823). Bally, Gordy; and Stewart (1966, p. 370) dated the deformation in Alberta as beginning in the Paleocene and continuing into late Eocene and Oligocene time. Deformation may have continued into the Oligocene; 
Russell (1954) dated a mammalian fauna from folded and faulted sediments in the Flathead Valley as very late Eocene or very early Oligocene. Haystack Butte, about 10 miles southeast of the Sun River Canyon area, is an igneous plug that intruded thrust-faulted and folded strata of the Two Medicine Formation (Upper Cretaceous). A potassium-argon age of 20 million years was obtained on hornblende from this plug by J. D. Obradovich (oral commun., 1969). Thus, the deformation in this area is probably no later than middle Miocene.

\section{REFERENCES CITED}

Alpha, A. G., 1955a, The Genou Trend of north central Montana: Am. Assoc. Petroleum Geologists, Rocky Mtn. Section, Geol. Rec., Feb. 1955, p. 131-138.

1955b, Tectonic history of north central Montana, in Billings Geol. Soc. Guidebook 6th Ann. Field Conf., Sept. 1955: p. 129-142.

Armstrong, F. C., and Oriel, S. S., 1965, Tectonic development of Idaho-Wyoming thrust belt: Am. Assoc. Petroleum Geologists Bull., v. 49 , no. 11, p. 1847-1866.

Badgley, P. C., 1965, Structural and tectonic principles: New York, Harper \& Row, $521 \mathrm{p}$.

Bally, A. W., Gordy, P. L., and Stewart, G. A., 1966, Structure, seismic data, and orogenic evolution of southern Canadian Rocky Mountains: Bull. Canadian Petroleum Geology, v. 14 , no. 3 , p. 337-381.

Beach, H. H., 1943, Moose Mountain and Morley map-areas, Alberta: Canada Geol. Survey Mem. 236, pub. 2468, 74 p.

Bevan, A. C., 1929, Rocky Mountain front in Montana: Geol. Soc. America Bull., v. 40, no. 2, p. 427-456.

Billings Geological Society, 1955, Sweetgrass arch-Disturbed belt, Montana, in Guidebook 6th Ann. Field Conf., 1955 $264 \mathrm{p}$.

Billings, M. P., 1942, Structural geology: New York, PrenticeHall, Inc., $473 \mathrm{p}$

Bossort, D. O., 1957 Relationship of the Porcupine Hills to early Laramide movements, in Alberta Soc. Petroleum Geologists Guidebook 7th Ann, Field Conf., 1957: p. 46-51.

Chamberlin, R. T., 1945, Basement control in Rocky Mountain deformation: Am. Jour: Sci., v. 243-A (Daly volume), p. 98116.

Chapman, R. H., 1900, Notes on the structure of the Rocky Mountains in the Lewis and Clark timber reserve, Montana: Am. Inst. Mining Engineers Trans., v. 29, p. 153-156.

Charlesworth, H. A. K., 1961, Some observations on deformation, crustal shortening, and uplift in the Canadian Rocky Mountains: Alberta Soc. Petroleum Geologists Jour., v. 9, no. 9, p. 255-269.

Childers, M. O., 1963, Structure and stratigraphy of the southwest Marias Pass area, Flathead County, Montana: Geol. Soc. America Bull., v. 74, no. 2, p. 141-163.

Choquette, A. L., 1959, Theoretical approach to foothills and mountain deformation of western Alberta: Alberta Soc. Petroleum Geologists Jour., v. 7, no. 10, p. 234-237.

Japp, C. H., 1932, Geology of a portion of the Rocky Mountains of northwestern Montana: Montana Bur. Mines and Geology Mem. 4, $30 \mathrm{p}$.

- 1934, Structure of the Coppers Lake quadrangle, Montana [abs.]: Geol. Soc. America Proc. 1933, p. 72.
Clark, L. M., 1954, Cross-section through the Clarke Range of the Rocky Mountains of southern Alberta and southern British Columbia, in Alberta Soc. Petroleum Geologists Guidebook 4th Ann. Field Conf., 1954: p. 105-109.

Cohee, G. V., chm., 1961, Tectonic Map of the United States, exclusive of Alaska and Hawaii: U.S. Geol. Survey and Am. Assoc. Petroleum Geologists [1962].

Deiss, C. F., 1935, Cambrian-Algonkian unconformity in western Montana: Geol. Soc. America Bull., v. 46, no. 1, p. 95-124.

- 1943a, Stratigraphy and structure of southwest Saypo quadrangle, Montana: Geol. Soc. America Bull., v. 54, no. 2, p. 205-262.

$1943 \mathrm{~b}$, Structure of central part of Sawtooth Range, Montana: Gecl. Soc. America Bull., v. 54, no. 8, p. 11231167.

Dobbin, C. E., and Erdmann, C. E., 1955, Structure contour map of the Montana plains: U.S. Geol. Survey Oil and Gas Inv. Map OM-178 A.

Donath, F. A., and Parker, R. B., 1964, Folds and folding: Geol. Soc. America Bull., v. 75, no. 1, p. 45-62.

Douglas, R. J. W., 1950, Callum Creek, Langford Creek, and Gap map areas, Alberta: Canada Geol. Survey Mem. 255, $124 \mathrm{p}$.

Flawn, P. T., chm., 1967, Basement map of North America: Am. Assoc. Petroleum Geologists and U.S. Geol. Survey.

Gallup, W. B., 1951, Geology of Turner Valley oil and gas field Alberta, Canada: Am. Assoc. Petroleum Geologists Bull., v. 35 , no. 4 , p. $797-821$.

Gilluly, James, 1960, A folded thrust in Nevada-inferences as to time relations between folding and faulting: Am. Jour. Sci., v. 258-A (Bradley volume), p. 68-79.

Gilluly, James, and Gates, Olcott, 1965, Tectonic and Igneous Geology of the Northern Shoshone Range, Nevada: U.S. Geol. Survey Prof. Paper 465, 153 p.

Hage, C. O., 1942, Folded thrust faults in Alberta Foothills west of Turner Valley: Royal Soc. Canada Trans., 3d ser., v. 36 , sec. 4 , p. $67-78$.

Hake, B. F., Willis, Robin, and Addison, C. C., 1942, Folded thrust faults in the Foothills of Alberta: Geol. Soc. America Bull., v. 53, no. 2, p. 291-334.

Holcombe, T. L., 1964, Geology of the Elk Creek area, Lewis and Clark County, Montana: Missouri Univ. unpub. M.A. thesis.

Hume, G. S., 1941, A folded fault in the Pekisko area; Foothills of Alberta: Royal Soc. Canada Trans., 3d ser., v. 35, sec. 4, p. 87-92.

1944, Petroleum geology of Canada: Canada Geol. Survey Econ. Geology ser. 14, 64 p.

-1957, Fault structures in the Foothills and eastern Rocky Mountains of southern Alberta: Geol. Soc. America Bull., v. 68 , no. 4 , p. 395-412.

Irish, E. J. W., 1965, Geology of the Rocky Mountain Foothills, Alberta (between latitudes $53^{\circ} 15^{\prime}$ and $54^{\circ} 15^{\prime}$ ): Canada Geol. Survey Mem. 334, 241 p.

Johns, W. M., 1964, Southeastern Flathead County and northern Lake County, pt. 6 of Progress report of geologic investigations in the Kootenai Flathead area, northwest Montana: Montana Bur. Mines and Geology Bull. 42, 66 p.

Kehle, R. O., 1970, Analysis of gravity sliding and orogenic translation: Geol. Soc. America Bull., v. 81, no. 6, p. 16411664.

King, P. B., 1959, The evolution of North America: Princeton Univ. Press. 190 p. 
1960, The anatomy and habitat of low-angle thrust faults: Am. Jour. Sci., v. 258-A (Bradley volume), p. $115-125$.

Link, T. A., 1949, Interpretations of Foothills structures, Alberta, Canada: Am. Assoc. Petroleum Geologists Bull., v. 33 , no. 9 , p. $1475-1501$.

1953, History of geological interpretation of the Turner Valley structure and Alberta foothills, Canada, in Alberta Soc. Petroleum Geologists 3d Ann. Field Conf. and Symposium, 1953: p. 117-133.

McGill, G. E., and Sommers, D. A., 1967, Stratigraphy and correlation of the Precambrian Belt Supergroup of the southern Lewis and Clark Range, Montana: Geol. Soc. America Bull., v. 78, no. 3, p. 343-351.

McMannis, W. J., 1965, Résumé of depositional and structural history of western Montana: Am. Assoc. Petroleum Geologists Bull., v. 49, no. 11, p. 1801-1823.

Merrill, Robert, 1965, Geology of the southern terminus of the Sawtooth Range, Montana: Massachusetts Univ. M.S. thesis.

Mudge, M. R., 1959, A brief summary of the geology of the Sun River Canyon area [Mont.], in Billings Geol. Soc. Guidebook 10th Ann. Field Conf., 1959: p. 18-22.

- 1965a, Bedrock geologic map of the Sawtooth Ridge quadrangle, Teton, and Lewis and Clark Counties, Montana: U.S. Geol. Survey Geol. Quad. Map GQ-381.

- 1965b, Rockfall-avalanche and rockslide-avalanche deposits at Sawtooth Ridge, Montana: Geol. Soc. America Bull., v. 76, no. 9, p. 1003-1014.

- 1966a, Geologic map of the Patricks Basin quadrangle, Teton, and Lewis and Clark Counties, Montana: U.S. Geol. Survey Geol. Quad. Map GQ-453.

1966b, Geologic map of the Pretty Prairie quadrangle, Lewis and Clark County, Montana: U.S. Geol. Survey Geol. Quad Map GQ-454.

1966c, Geologic map of the Glenn Creek quadrangle, Lewis and Clark, and Teton Counties, Montana: U.S. Geol. Survey Geol. Quad. Map GQ-499.

1967, Geologic map of the Arsenic Peak quadrangle, Teton, and Lewis and Clark Counties, Montana: U.S. Geol. Survey Geol. Quad. Map GQ-597.

- 1968, Bedrock geologic map of the Castle Reef quadrangle, Teton, and Lewis and Clark Counties, Montana: U.S. Geol. Survey Geol. Quad. Map GQ-711.

1970 , Origin of the disturbed belt in northwestern Montana: Geol. Soc. America Bull., v. 81, no. 2, p. 377-392.

1971, Gravitational sliding and the foreland thrust and fold belt of the North American Cordillera-Reply: Geol. Soc. America Bull., v. 82, no. 4, p. 1139-1140.

- 1972, Geology of the Sun River Canyon area, northwestern Montana: U.S. Geol. Survey Prof. Paper 663-A, $142 \mathrm{p}$.

Mudge, M. R., and Dobrovolny, Ernest, 1959, Road logAugusta to Gibson Reservoir, in Billings Geol. Soc. Guidebook 10th Ann. Field Conf., 1959: p. 154-158.

Mudge, M. R., Erickson, R. L., and Kleinkopf, Dean, 1968, Reconnaissance geology, geophysics, and geochemistry of the southeastern part of the Lewis and Clark Range, Montana, with spectrographic data by G. C. Curtin and A. P. Marranzino, and a section on Isotopic composition of lead, by R. E. Zartman: U.S. Geol. Survey Bull. 1252-E, $35 \mathrm{p}$.

Nolan, T. B., 1935, The Gold Hill mining district, Utah: U.S. Geol. Survey Prof. Paper 177, 172 p.
North, F. K., and Henderson, G. G. L., 1954, Summary of the geology of the southern Rocky Mountains of Canada, in Alberta Soc. Petroleum Geologists Guidebook 4th Ann Field Conf., 1954: p. 15-81.

O'Brien, C. A. E., 1960, The structural geology of the Boule and Bosche Ranges in the Canadian Rocky Mountains: Geol. Soc. London Quart. Jour., v. 116, pt. 4, p. 409-436.

Price, R. A., 1962, Geologic structure of the central part of the Rocky Mountains in the vicinity of Crowsnest pass: Alberta Soc. Petroleum Geologists Jour., v. 10, no. 7, p. $341-351$.

1965, Flathead map-area, British Columbia and Alberta: Canada Geol. Survey Mem. 336, 221 p.

1971, Gravitational sliding and the foreland thrust and fold belt of the North American Cordillera-Disscussion: Geol. Soc. America Bull., v. 82, no. 4, p. 1133-1138.

Price, R. A., and Mountjoy, E. W., 1970, Geologic structure of the Canadian Rocky Mountains between Bow and Athabasca Rivers-a progress report, in Structure of the southern Canadian Cordillera: Geol. Assoc. Canada Spec. Paper 6, p. 7-25.

Rich, J. L., 1934, Mechanics of low-angle overthrust faulting as illustrated by Cumberland thrust block, Virginia, Kentucky, and Tennessee: Am. Assoc. Petroleum Geologists Bull., v. 18, no. 12, p. 1584-1596.

Ross, C. P., 1959, Geology of Glacier National Park and the Flathead region, northwestern Montana: U.S. Geol. Survey Prof. Paper 296, 125 p. [1960].

Ross, C. P., Andrews D. A., and Witkind, I. J., compilers, 1955 , Geologic map of Montana: U.S. Geol. Survey, in cooperation with Montana Bur. Mines and Geology (repr. 1958).

Rubey, W. W., and Hubbert, M. K., 1959, Overthrust belt in geosynclinal area of western Wyoming in light of fluidpressure hypothesis, 2 of Role of fluid pressure in mechanics of overthrust faulting: Geol. Soc. America Bull., v. 70, no. 2, p. 167-205.

Russell, L. S., 1951, Age of the front-range deformation in the North American Cordillera: Royal Soc. Canada Trans., $3 \mathrm{~d}$ ser., v. 45 , sec. 4 , p. 47-69.

-1954, Mammalian fauna of the Kishenehn formation, southeastern British Coulmbia: Canada Natl. Mus. Bull. 132, p. 92-111.

Schmidt, R. G., 1963, Preliminary geologic map and sections of the Hogan 4 Southeast quadrangle, Lewis and Clark County, Montana: U.S. Geol. Survey Misc. Geol. Inv. Map I-379.

Scott, J. C., 1951, Folded faults in Rocky Mountain foothills of Alberta, Canada: Am. Assoc. Petroleum Geologists Bull., v. 35, no. 11, p. 2316-2347.

Shaw, E. W., 1963, Canadian Rockies-Orientation in time and space, in Childs, O. E., and Beebe, B. W., eds., Backbone of the Americas: Am. Assoc. Petroleum Geologists Mem. 2, p. 231-242.

Sitter, L. U. de, 1956, Structural geology: McGraw-Hill Book Co., $552 \mathrm{p}$.

Sloss, L. L., 1950, Paleozoic sedimentation in Montana area: Am. Assoc. Petroleum Geologists Bull., v. 34, no. 3, p. $423-451$.

Sommers, D. A., 1966, Stratigraphy and structure of a portion of the Bob Marshall Wilderness Area, northwestern Montana: Massachusetts Univ. Ph. D. thesis, 234 p.

Staatz, M. H., and Albee, H. F., 1966, Geology of the Garns Mountain quadrangle, Bonneville, Madison, and Teton Counties, Idaho: U.S. Geol. Survey Bull. 1205, 122p. 
Stebinger, Eugene, 1917, Anticlines in the Blackfeet Indian Reservation, Montana: U.S. Geol Survey Bull. 641-J, p. 281-305.

1918, Oil and gas geology of the Birch Creek-Sun River area, northwestern Montana: U.S. Geol. Survey Bull. 691-E, p. 149-184.

Tozer, I. T., 1953, The Cretaceous-Tertiary transition in southwestern Alberta, in Alberta Soc. Petroleum Geologists 3d Ann. Field Conf. and Symposium, 1953: p. 23-31.
Viele, G. W., 1960, The geology of the Flat Creek area, Lewis and Clark County, Montana: Utah Univ. Ph. D. thesis. Walcott, C. D., 1906, Algonkian formations of northwestern Montana: Geol Soc. America Bull., v. 17, p. 1-28.

Weimer, R. J., 1955, Geology of the Two Medicine-Badger Creek area, Glacier and Pondera Counties, Montana, in Billings Geol. Soc. Guidebook 6th Ann. Field Conf., 1955: p. 143-149. 



\section{INDEX}

[Italic page numbers indicate major references]

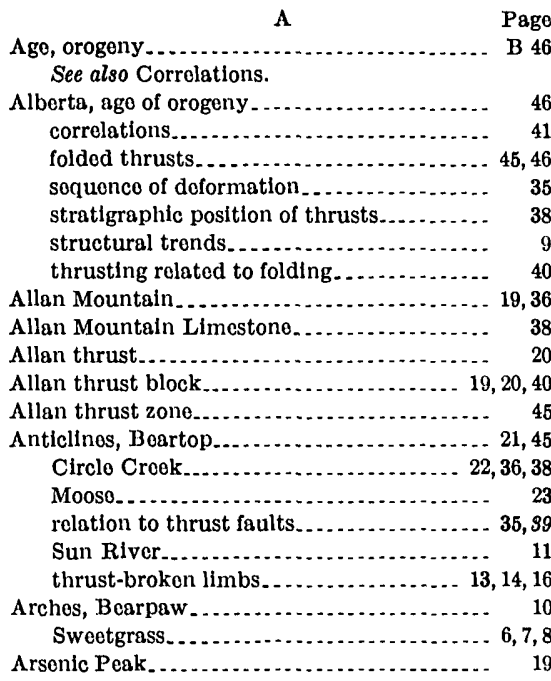

Barr thrust.

Basement rocks.

Battle Creek

Bear Lako

Bearpaw arch................................... 10

Beartop anticlino............................ 21,45

Beaver Croek................................ 17

Belt Supergroup

Bench Mark Creek ......................... 23, 36

Big Belt uplift..

Biggs Creek syncline........................ 21,45

Birch Creek-Sun River area................ 11

Black Reef................................. 21

Blackleaf Formation......................... 15

Flood Shale Member................. 17, 36, 38

Taft Hill Member...................... 46

trachyandesite sill................... 21, 23,36

Vaughn Momber........................ 18

Blacktall fault ..................................... 27

Boulder batholith......................... 10,34

Broccia, fault........................... 17, 26, 46

solution ................................. 38

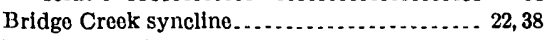

Brockton-Froid fault zone...

\section{C}

Cabin Creek.

21,45

Canada, Alberta. See Alberta.

structural trends.

Castlo Reef.

Contral Montans trough

Chamberlín, R. T., quoted

Circle Creek anticline. $\ldots . \ldots \ldots \ldots \ldots \ldots . . .22,36,38$

Competent rocks. .......................... 35, 36

Helena Dolomite........................ 35

sills

See also Incompetent rocks.

Compressional stress

33

Confining prossure.

35,36

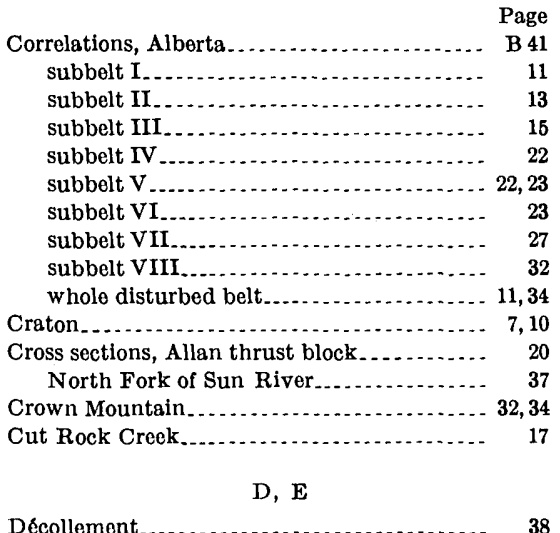

collement................................ 38

Deep Creek............................. 12, 18, 19

Deep Creek thrust block $\ldots \ldots \ldots$

Depth of burial.

Depth of thrusting. -

Devils Glon Dolomite

Displacement, aggregate horizontal .......... aggregate vertical.

normal faults, subbelt $I$

subbelt II.

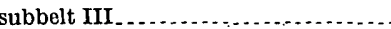

subbelt VII ..........................

subbelt VIII.

subbelt IX.

thrust faults, subbr

(n)

subbelt II.

subbelt IV

subbelt V

subbelt VI.

subbelt VII.

subbelt VIII

subbelt IX

Lak 0 . . . . .

Diversion Ridge.

Diversion thrust. $\ldots \ldots \ldots \ldots \ldots \ldots \ldots \ldots \ldots \ldots . . .15,17,41$

Diversion thrust block $\ldots \ldots \ldots \ldots$

Deep Creek thrust block..............

Domes, Kevin-Sunburst

Drill holes, Willow Creek See also Wells.

Elk fault. $17,22,33,38$

Facies changes

Fault blocks. See Thrust blocks.

Fault complexes, Pretty Prairie . ....... 29, 36, 37, 45

Fault zones. . . . . . . . .

Faulting

Foults, basement Blacktail................................ 27

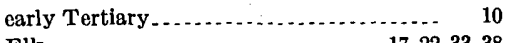
Elk_............................. 17, 22, 33, 38 Glenn ............................... 31,33 Hinsdale .................. 10 normal. See Normal faults. stress.
Faults-Continued

Page

(17,33

thrust. See Thrust faults.

transverse .......................... 9, 17,33

Vananda ............................ 10

Weldon

Fensters................................. 19, 36

Flathead V alley . -

Flood Shale Member, Blackleaf Formation. 17, 36, 38

Fluid pressure............................ .. 40

Folding, controlling factors $. . . . . . \ldots \ldots \ldots . . .$.

mechanics............................ 33

relation to thrusting ...................... 39

Folds, anticlines. See Anticlines.

basement............................ 7,10

beneath thrusts......................... 16

drag. ...................................... 14, 20

early Tertiary ......................... 10

flexural-flow . .

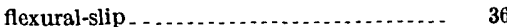

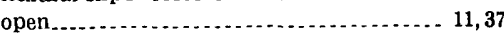

relation to thrust faults..................

stress.

subbelt I.

subbelt IV

subbelt $\mathrm{V}$

subbelt VI.

synclines. See Synclines.

Foothills.

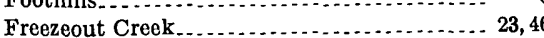

French Gulch

French thrust.............................. 41

Fromberg fault zone......... 10

Front Ranges.

G, H, I

Glacier National Park................. 6, 10,27

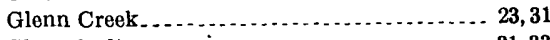

Glenn fault $\ldots \ldots \ldots \ldots \ldots \ldots \ldots \ldots \ldots \ldots \ldots . . .31,33$

Gravity sliding........................... 33, 35, 36, 40

Grouse Creek.

Hannan Gulch........................... 16

Helena Dolomite

Hinsdale fault ............................ 10

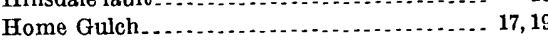

Home thrust. . . . . . . .

Home thrust block. ........................ 19

Imbricate zones $\ldots 11,14,20,27$

back-limb thrusts. . . . . . . . . . . . . . . . . . .

Mesozoic................................. 36, 44

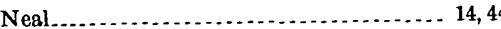

origin..................................... 44

relation to anticlines...................... 39

relation to fault steepness................. 30

relation to lithology ..................... 36

Stecker. . ................................ 14,44

Incompetent rocks ..................... 16, 17,35, 98

See also Competent rocks.

Interior Lowlands. 


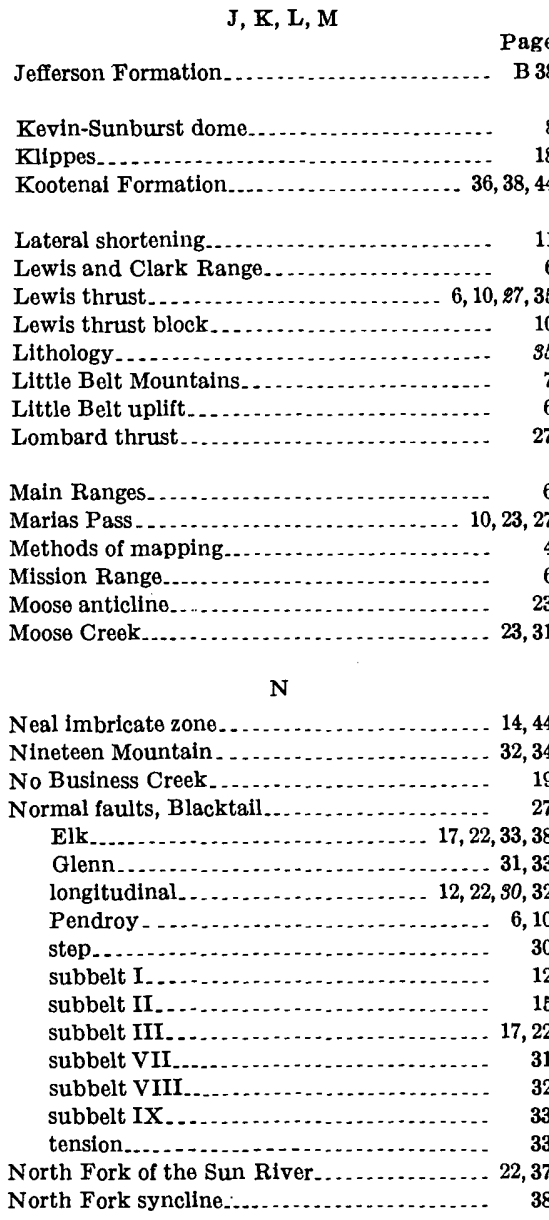

\section{O, P, R}

Orogeny, age............................. 46

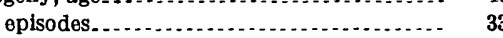

Pagoda Limestone . . . . . . . . . . . . . . . .

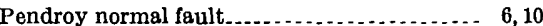

Physiography ............................. 4

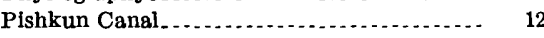

Prairie Reef.

Pretty Prairie fault complex $\ldots \ldots . .23,36,37,45$

Previous studies

Regional setting........................ 4

Renshaw thrust............................ 26, 34

Rierdon Formation................... 16, 38,44

Sawtooth Range.

$6,10,15,19$

Sawtooth Ridge........................... 16,17, 19

Saw tooth thrust............................... 19,41

Sawtooth thrust block...................... 19

Scapegoat-Bannatyne trend ................. 6,9

Sequence of deformation........

Sequenco

Shear flow

Sheep Mountain

Sheep Reef

Shepard Formation 38

Shortening, lateral . ........................ 11

Sills, Blackleaf Formation................. 21, 23, 36

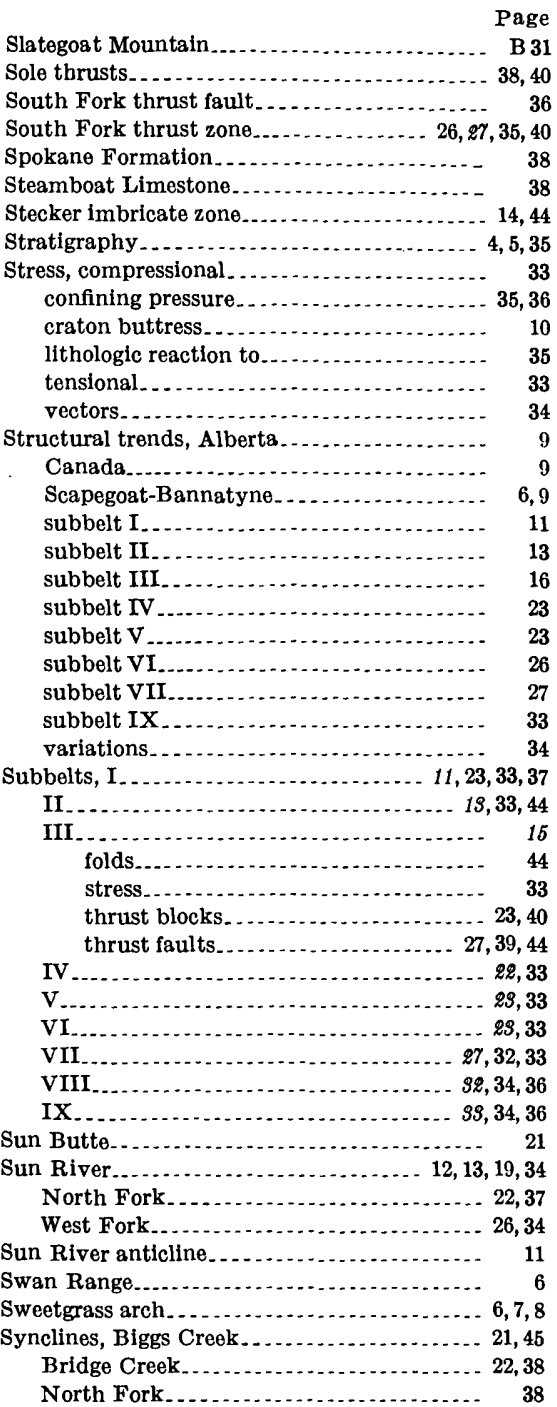

Taft Hill Member, Blackleaf Formation. ..... $\quad 46$ Tear faults............................... 9, 17, 33 Tensional stress.

Terminology, subbelt

Three Forks Formation............. 38

Thrust blocks, Allan................. 19, 20,40

Deep Creek $\ldots$

Diversion............................... 18

Home.

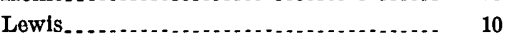

Sawtooth ................. 10

Thrust faulting. See Thrusting.

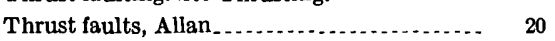
anomalous trend. anticline limbs. . . . . . . . . . . . . . . 13, 14, 16 back-limb......................... 16, 20,39,41 Barr bedding brecciated

B $17,26,46$
Thrust faults-Continued Page

change in stratigraphic position.......... 38

compression............................ 33

dips........................................ 41

Diversion . . . ....................... 15, 17, 41

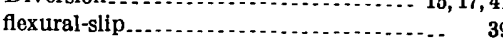

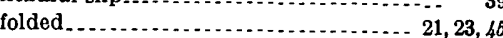

French.............................. 41

Home.............. 10

Lewis . . . . . . . . . . . . . . . . . . . . 6, 10, 27,35

Lombard.............................. 27

relation of steepness to imbrication. .......

relation to anticlines.................... 35, 89

relation to dip of strata

relation to folds...........................

relation to strike of strata................

Renshaw .............................. 26, 34

repetition of strata..................... 27

Sawtooth $\ldots . . \ldots \ldots \ldots \ldots \ldots \ldots \ldots \ldots . . . \ldots 19,41$

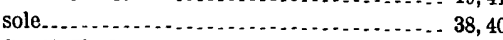

South Fork $\ldots \ldots \ldots \ldots \ldots$

steplike.................................. 38

stress causing...........................

strike.......................................

subbelt I. . . . .

subbelt II ........................... 14, 15

subbelt III . . ...................... 16, 20,39

subbelt IV ............................ 23

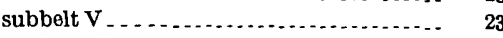

subbelt VI . . . .

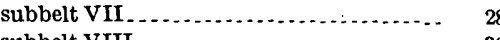

subbelt VIII $\ldots \ldots \ldots$

subbelt IX .......................... 33

Thrust plates, distance of travel ............. 46

folded ................................. 21, 23, 46

origin........................... 46

Pretty Prairie fault complex ...... 23, 36, 45 relation to basement structures. . . . ...... 10

Thrust zones, Allan. . ...................... 45

South Fork . . . . . . .

West Fork $\ldots \ldots \ldots \ldots \ldots \ldots \ldots \ldots$

Thrusting, absence of folding .............. 40

back-limb stress. ..........................

controlling factors . . . . .

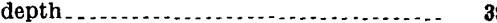

distance of plate travel . . . . . ............. 40

initial .............

mechanics.

relation to folding

relation to rock competence

Thrusts. See Thrust faults.

Transverse faults ........................ 9, 17,33

Two Medicine-Badger Creek area . ........... 11, 33

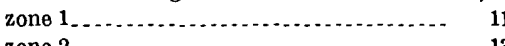

zone $2 . \ldots \ldots \ldots . .13$

zone 3................................. 15

zone 4 .

\section{$\mathrm{U}, \mathrm{v}, \mathrm{w}$}

Unconformities...........

cause of lateral compression. . ............ 33, 35

Little Belt . . . . . . . . . . 6

Vananda fault............................ 10

Vaughn Member, Blackleaf Formation ....... 18

Wagner Basin $\ldots \ldots \ldots \ldots \ldots \ldots \ldots \ldots \ldots \ldots . . . \ldots \ldots$

Weldon fault . . . . . . .

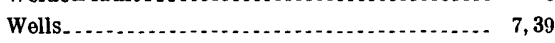

See also Drill holes.

West Fork of the Sun River............... 26,34

West Fork thrust zone..................... 32,34

Willow Creek 